\title{
Contemporary Environmental Assessment Using a Viability Analysis in a Large River System to Inform Restoration and Adaptive Management Decisions
}

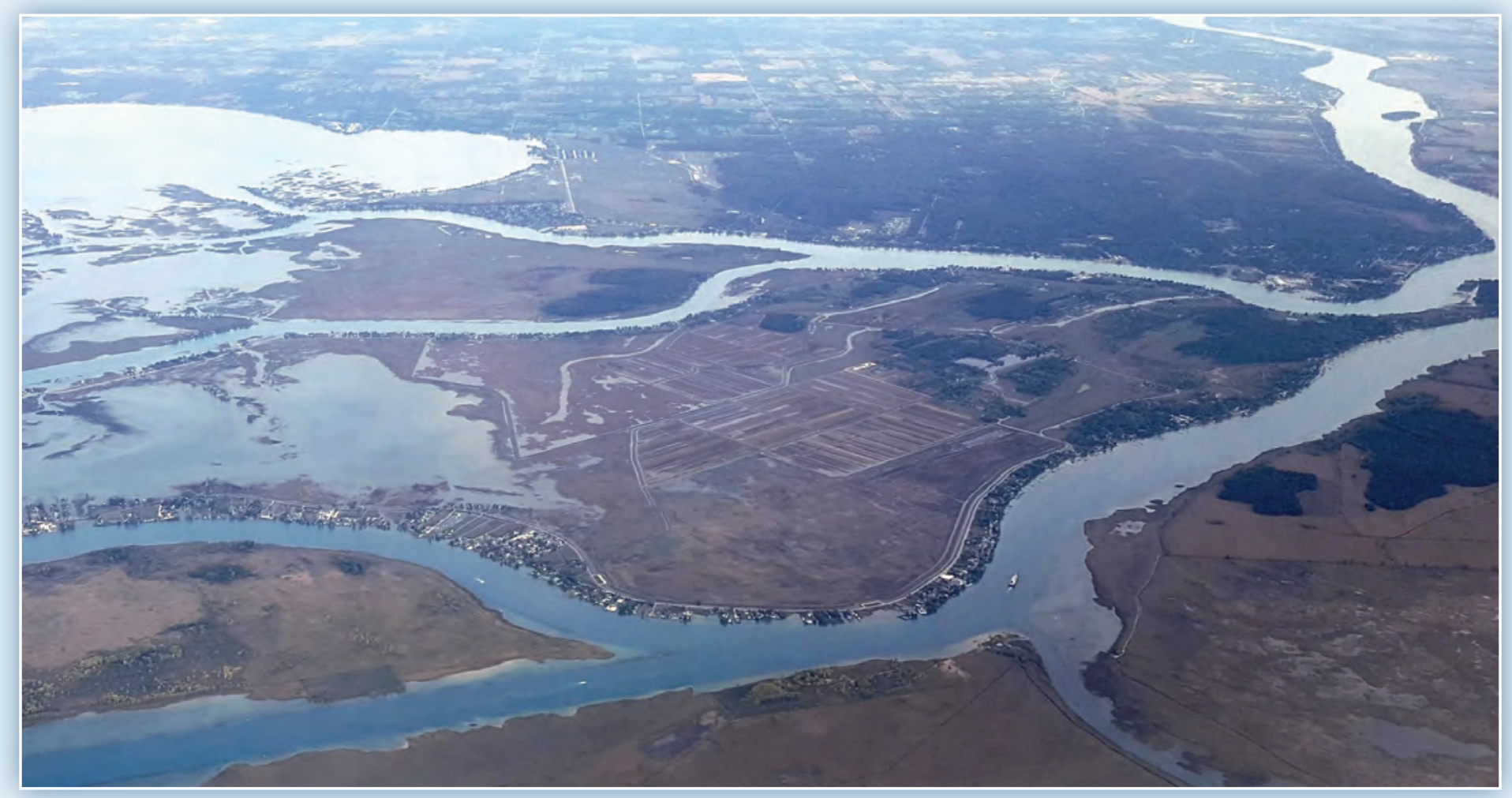

Scientific Investigations Report 2019-5002 
Cover. View of the St. Clair River looking from the delta at Lake St. Clair northward toward Lake Huron, October 2016. Photograph by Dimitry Gorsky, U.S. Fish and Wildlife Service. 


\section{Contemporary Environmental Assessment Using a Viability Analysis in a Large River System to Inform Restoration and Adaptive Management Decisions}

By Robin L. DeBruyne, Edward F. Roseman, Jason E. Ross, Kurt R. Newman, and Russell M. Strach

Scientific Investigations Report 2019-5002 


\title{
U.S. Department of the Interior \\ DAVID BERNHARDT, Acting Secretary
}

\author{
U.S. Geological Survey \\ James F. Reilly II, Director
}

U.S. Geological Survey, Reston, Virginia: 2019

For more information on the USGS - the Federal source for science about the Earth, its natural and living resources, natural hazards, and the environment-visit https://www.usgs.gov or call 1-888-ASK-USGS.

For an overview of USGS information products, including maps, imagery, and publications,

visit https://store.usgs.gov.

Any use of trade, firm, or product names is for descriptive purposes only and does not imply endorsement by the U.S. Government.

Although this information product, for the most part, is in the public domain, it also may contain copyrighted materials as noted in the text. Permission to reproduce copyrighted items must be secured from the copyright owner.

Suggested citation:

DeBruyne, R.L., Roseman, E.F., Ross, J.E., Newman, K.R., and Strach, R.M., 2019, Contemporary environmental assessment using a viability analysis in a large river system to inform restoration and adaptive management decisions: U.S. Geological Survey Scientific Investigations Report 2019-5002, 59 p.,

https://doi.org/10.3133/sir20195002.

ISSN 2328-0328 (online) 


\section{Acknowledgments}

The authors of this report thank the following partners who contributed to this report:

R. Burns, J. Chiotti, J. Diana, J. Dettmers, M. DuFour, R. Ellison, T. Kalish, W. Keiper, R. Knight, S. McNaught, D. Pearsall, P. Seelbach, M. Selzer, and D. Tozer. This manuscript was improved by the comments and suggestions from M. Selzer and anonymous reviewers. Non-published data referenced in this report are available upon request from the professionals and organizations listed in the Appendix for the specific indicator description. This work was funded by the U.S. Environmental Protection Agency Great Lakes Restoration Initiative.

The authors of this report thank the following U.S. Geological Survey personnel for their contributions: D. Bennion, J. Craig, M. Evans, D. Hondorp, G. Kennedy, and C. Vandergoot. 



\section{Contents}

Acknowledgments ……...................................................................................................................

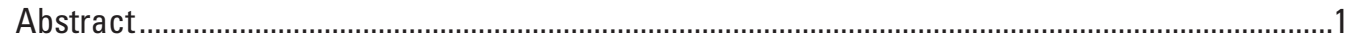

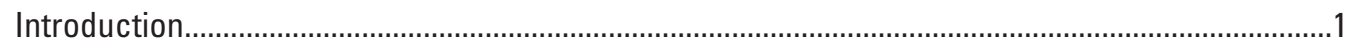

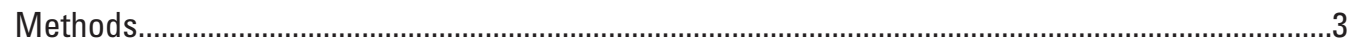

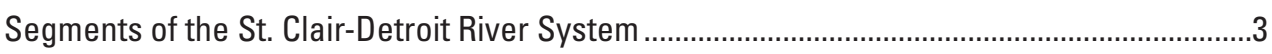

Conservation Targets in the St. Clair-Detroit River System ....................................................

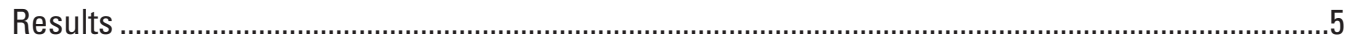

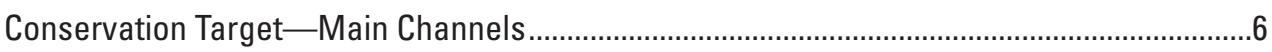

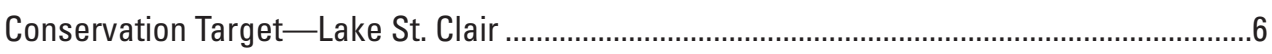

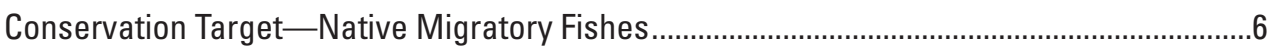

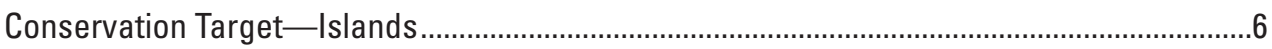

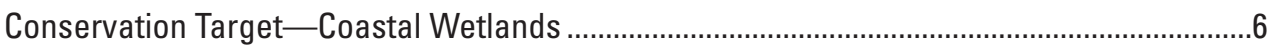

Conservation Target—Coastal Terrestrial Systems .....................................................................

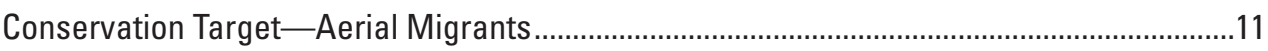

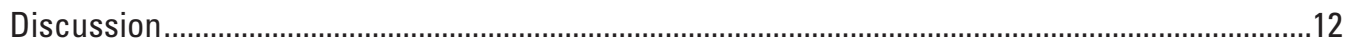

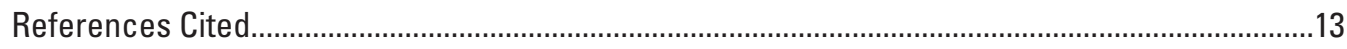

Appendix 1. Indicator Descriptions ...................................................................................

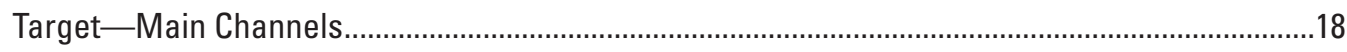

Key Ecological Attribute—Channel Condition ...................................................................18

Artificial Shoreline Hardening Index .....................................................................18

Percent River Flow Through Chenal Ecarte ....................................................................18

Key Ecological Attribute —Community Architecture ..........................................................19

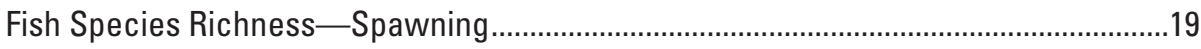

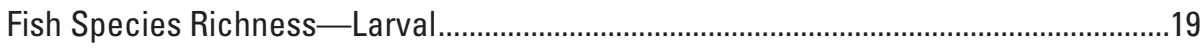

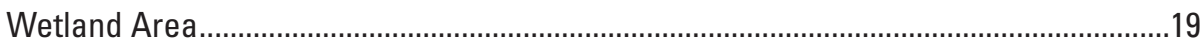

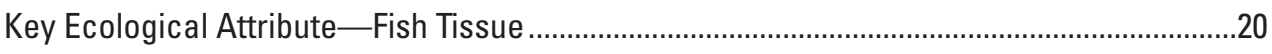

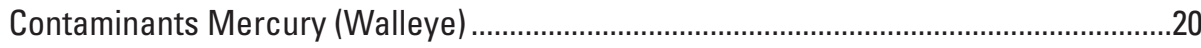

Contaminants Polychlorinated Biphenyls (Walleye)......................................................20

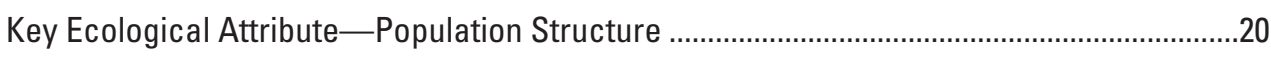

Mean 5-Year Annual Peak Density of Lake Whitefish Larvae..........................................20

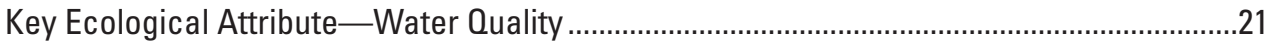

Mean 3-year Density of Hexagenia .................................................................................21

Mean Growing Season (March-October) Water Level ................................................21

Total Dissolved Solids ............................................................................................22

Total Phosphorus Concentrations ............................................................................22

Percent of Beaches Open During Summer E. coli Monitoring.......................................22

Key Ecological Attribute—Population Size and Dynamics ..................................................2

Mean Native Mussel Richness Per Site .......................................................................23

Mean Dreissena Density ........................................................................................2

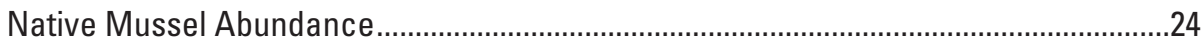

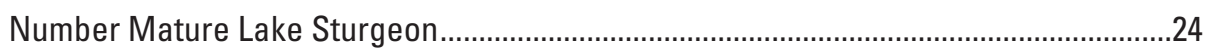

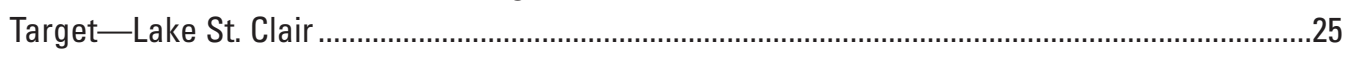

Key Ecological Attribute—Community Architecture .............................................................25 
3-Year Running Average Total Native Intolerant Fish Species Richness in Annual

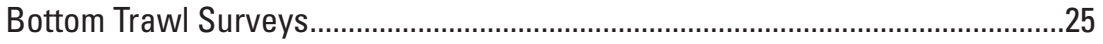

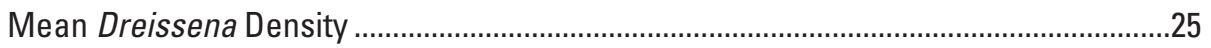

Smallmouth Bass Population/Relative Abundance ……….............................................25

Walleye Population/Relative Abundance .........................................................................26

Yellow Perch Population/Relative Abundance ................................................................26

Muskellunge Population/Relative Abundance .................................................................27

Key Ecological Attribute—Soil/Sediment Stability and Movement ..........................................27

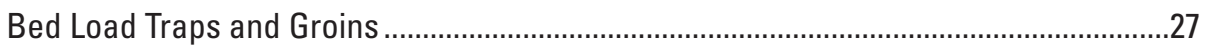

Erosion and Deposition Rates (From Tributaries) …………...........................................27

Key Ecological Attribute—Coastal and Watershed Contribution...............................................28

Artificial Shoreline Hardening Index ...........................................................................28

Percent Natural Land Cover in Watershed ..................................................................28

Percent Natural Land Cover within 2 Kilometers of Lake/Shoreline................................29

Key Ecological Attribute—Landscape Pattern (Mosaic) and Structure ...................................29

Emergent and Submergent Vegetation Distribution in Protected Embayments

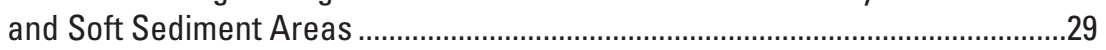

Key Ecological Attribute—Water Quality …….................................................................

Dissolved Phosphorus Loads.........................................................................................30

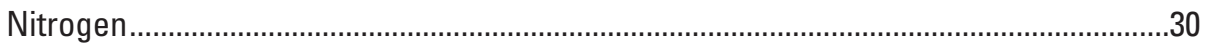

Total Phosphorus Concentrations ..............................................................................30

Cladophora Standing Crop During Late Summer (August-September) ..........................31

Contaminants Mercury (Walleye) .................................................................................31

Contaminants Polychlorinated Biphenyls (Walleye).....................................................31

Extent of Harmful Algal Blooms (for example, Microcystis, Lyngbya)............................32

Percent of Beaches Open During Summer E. coli Monitoring.......................................32

Key Ecological Attribute_Population Size and Dynamics .....................................................32

Mean Native Mussel Richness Per Site …….............................................................32

Key Ecological Attribute—Food Web Linkages..................................................................3

Mean 3-year Density of Hexagenia ...........................................................................33

Mean Densities of Rotifers, Copepods, and Cladocerans in Early Summer .....................33

Target—Native Migratory Fishes..........................................................................................

Key Ecological Attribute—Access to Spawning Areas ........................................................34

Percent of Accessible Headwater Stream Habitat (Stream Order 1) ..............................34

Percent of Accessible Creek Habitat (Stream Order 2-3) .................................................34

Percent of Accessible Small River Habitat (Stream Order 4-5) ........................................35

Percent of Accessible Large River Habitat (Stream Order 6 or greater) ........................35

Percent of Accessible Tributary Wetland Habitat........................................................35

Area of Main Channels Habitat Suitable for Lithophilic Spawners...................................36

Key Ecological Attribute-Population Size and Dynamics ...................................................36

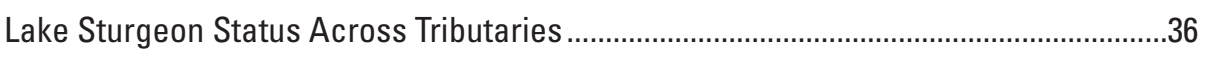

Status of Shorthead Redhorse Across Tributaries..............................................................37

Status of Walleye Across Tributaries ..........................................................................

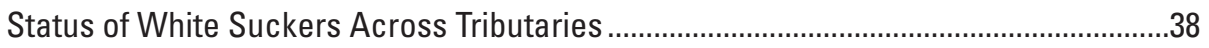

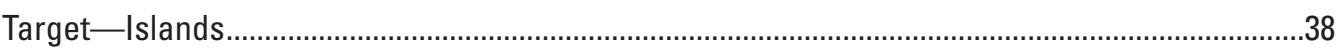

Key Ecological Attribute-Connectivity Among Communities and Ecosystems .....................38 
Road Density on Islands ..................................................................................................38

Key Ecological Attribute—Landscape Pattern (Mosaic) and Structure .................................39

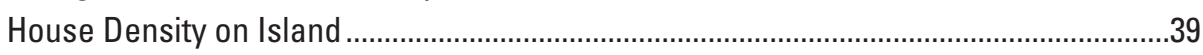

Key Ecological Attribute-Size/Extent of Characteristic Communities/Ecosystems...............39

Percent Natural Land Cover on Entire Island ..................................................................39

Key Ecological Attribute—Soil/Sediment Stability and Movement .........................................40

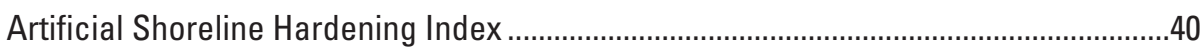

Bed Load Traps and Groins ..........................................................................................

Key Ecological Attribute - Conservation Status ...................................................................

Percentage of High-Ranked Islands that are in Conservation Status ............................41

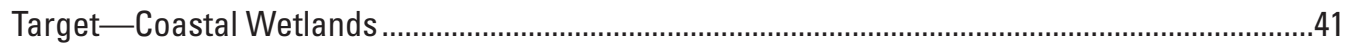

Key Ecological Attribute-Abundance and Diversity of Amphibians.....................................41

Amphibian Community-Based Coastal Wetland Index of Biotic Integrity........................41

Key Ecological Attribute-Abundance and Diversity of Wetland Dependent

Bird Species ..........................................................................................................

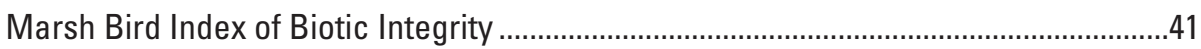

Key Ecological Attribute—Fish Habitat Quality ....................................................................42

Wetland Fish Index of Wetland Quality ........................................................................42

Key Ecological Attribute-Macroinvertebrate Quality .........................................................42

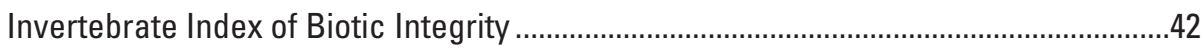

Key Ecological Attribute-Species Composition/Dominance ................................................4

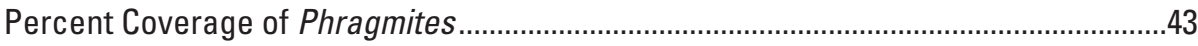

Key Ecological Attribute—Species Composition/Dominance ................................................43

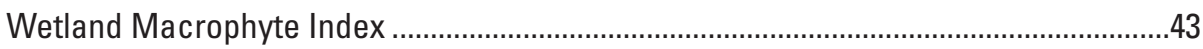

Key Ecological Attribute-Spawning Habitat Quality and Accessibility ...............................4

Spawning/Recruitment Success of Representative Coastal Wetland Spawners ..........43

Key Ecological Attribute-Trophic Structure ......................................................................4

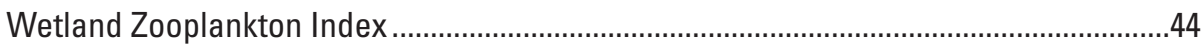

Key Ecological Attribute —Connectivity Among Communities and Ecosystems .....................44

Percent Natural Land Cover in Watershed ..................................................................44

Key Ecological Attribute-Connectivity Among Communities and Ecosystems .....................45

Percent Natural Land Cover within 500 meters of Mapped Wetlands ............................45

Key Ecological Attribute —Water Level Regime...............................................................4

Mean Growing Season (March-October) Water Level ................................................45

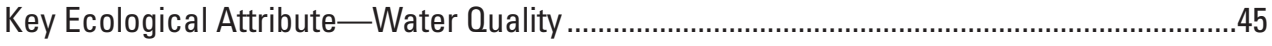

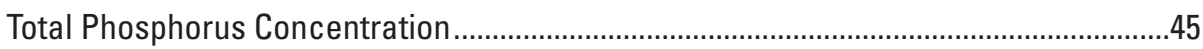

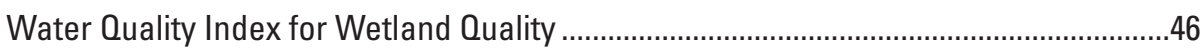

Key Ecological Attribute-Size/Extent of Characteristic Communities ....................................46

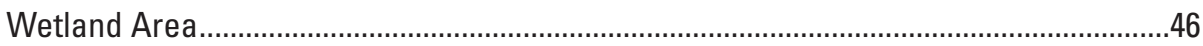

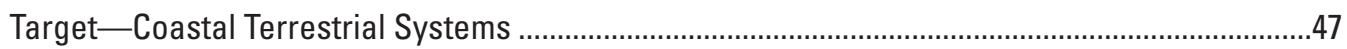

Key Ecological Attribute-Connectivity Among Communities and Ecosystems .....................47

Road Density Within 2 Kilometers of Shoreline ..............................................................47

Key Ecological Attribute_Landscape Pattern (Mosaic) and Structure ..................................47

House Density Within 500 Meters of Coast.......................................................................47

Key Ecological Attribute-Extent of Characteristic Communities/Ecosystems ......................47

Percent Natural Land Cover within 2 Kilometers of Lake/Shoreline.................................47 
Key Ecological Attribute-Soil/Sediment Stability and Movement ........................................48

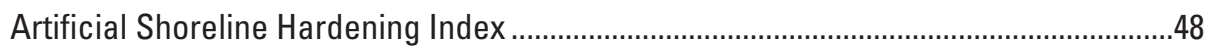

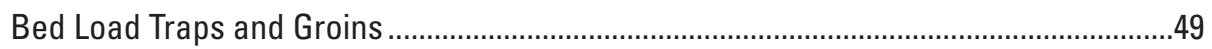

Key Ecological Attribute-Size/Extent of Characteristic Communities/Ecosystems..............49

Percentage of Area 2-10 Kilometers From Lake that is in Natural Land Cover .............49

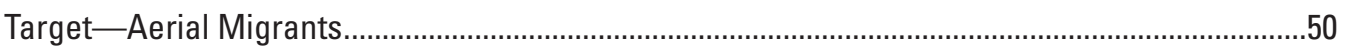

Key Ecological Attribute_Anthropogenic Disturbance .........................................................50

Mean Distance of Suitable Shorebird Habitat From Disturbance Factor .......................50

Mean Distance of Suitable Waterfowl Habitat From Disturbance Factor .......................50

Key Ecological Attribute — Habitat Availability ......................................................................51

Percentage of 2 Kilometers Shoreline Area Suitable for Shorebirds ............................51

Percentage of 2 Kilometers Shoreline Area Suitable Habitat for Landbirds ...................51

Percentage of 2 Kilometers Shoreline Area Suitable Habitat for Waterfowl ..................51

Key Ecological Attribute—Management Status ...............................................................52

Percentage of High Priority Habitat Across All Bird Groups in Conservation

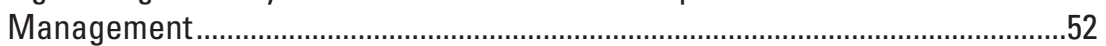

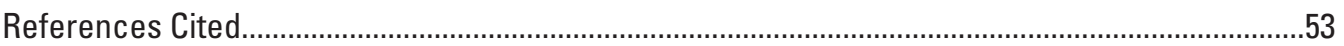

\section{Figure}

1. Map of the St. Clair-Detroit River System study area...........................................................

\section{Tables}

1. Target indicator ratings and corresponding rating descriptions used for the St. Clair-Detroit River System viability assessment.

2. Viability analysis results for the overall condition of the seven conservation targets assessed in each of the assessment units.

3. Viability analysis results for the main channels target ....................................................

4. Viability analysis results for Lake St. Clair target.............................................................

5. Viability analysis results for native migratory fishes and islands targets..........................

6. Viability analysis results for coastal wetlands ............................................................10

7. Viability analysis results for coastal terrestrial systems and aerial migrants..................11 


\section{Conversion Factors}

International System of Units to U.S. customary units

\begin{tabular}{|c|c|c|}
\hline Multiply & By & To obtain \\
\hline \multicolumn{3}{|c|}{ Length } \\
\hline meter $(\mathrm{m})$ & 3.281 & foot $(\mathrm{ft})$ \\
\hline kilometer $(\mathrm{km})$ & 0.6214 & mile (mi) \\
\hline kilometer $(\mathrm{km})$ & 0.5400 & mile, nautical (nmi) \\
\hline meter $(\mathrm{m})$ & 1.094 & yard (yd) \\
\hline \multicolumn{3}{|c|}{ Area } \\
\hline square meter $\left(\mathrm{m}^{2}\right)$ & 0.0002471 & acre \\
\hline hectare (ha) & 2.471 & acre \\
\hline square kilometer $\left(\mathrm{km}^{2}\right)$ & 247.1 & acre \\
\hline square meter $\left(\mathrm{m}^{2}\right)$ & 10.76 & square foot $\left(\mathrm{ft}^{2}\right)$ \\
\hline hectare (ha) & 0.003861 & square mile $\left(\mathrm{mi}^{2}\right)$ \\
\hline square kilometer $\left(\mathrm{km}^{2}\right)$ & 0.3861 & square mile $\left(\mathrm{mi}^{2}\right)$ \\
\hline \multicolumn{3}{|c|}{ Volume } \\
\hline liter (L) & 33.82 & ounce, fluid (fl. oz) \\
\hline liter $(\mathrm{L})$ & 0.2642 & gallon (gal) \\
\hline cubic meter $\left(\mathrm{m}^{3}\right)$ & 264.2 & gallon (gal) \\
\hline liter $(\mathrm{L})$ & 61.02 & cubic inch $\left(\mathrm{in}^{3}\right)$ \\
\hline cubic meter $\left(\mathrm{m}^{3}\right)$ & 35.31 & cubic foot $\left(\mathrm{ft}^{3}\right)$ \\
\hline cubic meter $\left(\mathrm{m}^{3}\right)$ & 1.308 & cubic yard $\left(\mathrm{yd}^{3}\right)$ \\
\hline \multicolumn{3}{|c|}{ Mass } \\
\hline $\operatorname{gram}(\mathrm{g})$ & 0.03527 & ounce, avoirdupois (oz) \\
\hline kilogram (kg) & 2.205 & pound avoirdupois (lb) \\
\hline metric tons $(\mathrm{t})$ & 1.102 & Ton, short $(2,000 \mathrm{lb})$ \\
\hline
\end{tabular}

Temperature in degrees Celsius $\left({ }^{\circ} \mathrm{C}\right)$ may be converted to degrees Fahrenheit $\left({ }^{\circ} \mathrm{F}\right)$ as

$$
{ }^{\circ} \mathrm{F}=\left(1.8 \times{ }^{\circ} \mathrm{C}\right)+32 .
$$

Temperature in degrees Fahrenheit $\left({ }^{\circ} \mathrm{F}\right)$ may be converted to degrees Celsius $\left({ }^{\circ} \mathrm{C}\right)$ as

$$
{ }^{\circ} \mathrm{C}=\left({ }^{\circ} \mathrm{F}-32\right) / 1.8 \text {. }
$$

\section{Supplemental Information}

Concentrations of chemical constituents in water are given in either milligrams per liter (mg/L) or micrograms per liter $(\mu \mathrm{g} / \mathrm{L})$. 
Abbreviations

C-CAP Coastal Change Analysis Program

CPUE catch-per-unit-effort

ELSC eastern Lake St. Clair

$\mathrm{gDW} / \mathrm{m}^{2} \quad$ grams dry weight per square meter

GIS geographic information system

GLRI Great Lakes Restoration Initiative

GLWOA Great Lakes Water Quality Agreement

IBI index of biotic integrity

KEA key ecological attributes

$\mathrm{km} \quad$ kilometer

LDR lower Detroit River

LEBCS Lake Erie Biodiversity Conservation Strategy

LOBCS Lake Ontario Biodiversity Conservation Strategy

L liter

LSCR lower St. Clair River

m meter

$\mathrm{m} / \mathrm{km}^{2} \quad$ meter per square kilometer

$\mathrm{m}^{2} \quad$ square meter

$\mathrm{m}^{3} \quad$ cubic meter

MDEO Michigan Department of Environmental Quality

MDNR Michigan Department of Natural Resources

$\mu \mathrm{g} / \mathrm{g} \mathrm{WW}$ micrograms per gram wet weight

$\mu \mathrm{g} / \mathrm{L} \quad$ micrograms per liter

MSCR middle St. Clair River

$\mathrm{mg} / \mathrm{L} \quad$ milligrams per liter

NOAA National Oceanic and Atmospheric Administration

OMNRF Ontario Ministry of Natural Resources and Forestry

$\% \quad$ percent

PCBs polychlorinated byphenyls

SCDRS St. Clair-Detroit River System

SCDRSI St. Clair-Detroit River System Initiative

SO stream order

SOLEC State of the Lakes Ecosystem Conference

spp. $\quad$ species 


$\begin{array}{ll}\text { t/ac/yr } & \text { tons per acre per year } \\ \text { TBD } & \text { to be determined } \\ \text { TDS } & \text { total dissolved solids } \\ \text { UDR } & \text { upper Detroit River } \\ \text { USCR } & \text { upper St. Clair River } \\ \text { USFWS } & \text { U.S. Fish and Wildlife Service } \\ \text { USGS } & \text { U.S. Geological Survey } \\ \text { WLSC } & \text { western Lake St. Clair }\end{array}$





\title{
Contemporary Environmental Assessment Using a Viability Analysis in a Large River System to Inform Restoration and Adaptive Management Decisions
}

\author{
By Robin L. DeBruyne, ${ }^{1}$ Edward F. Roseman, ${ }^{2}$ Jason E. Ross,${ }^{3}$ Kurt R. Newman, ${ }^{2}$ and Russell M. Strach ${ }^{2}$
}

\section{Abstract}

As large-scale restoration plans for degraded aquatic habitats evolve, it is essential that multiorganizational collaborations have a common vision to achieve consensus on restoration goals. Development of restoration targets and postrestoration monitoring strategies can be focused using a viability analysis framework that supports an adaptive management process. Viability analysis is a robust and accommodating framework, adaptable to any restoration monitoring program and, through the determination of common desired endpoints, can aid consensus building and collaboration across jurisdictional boundaries. In the St. Clair-Detroit River System, which is the Great Lakes connecting channel between southern Lake Huron and western Lake Erie, a viability analysis framework was used to evaluate environmental parameters associated with fisheries and aquatic restoration efforts and to gauge the overall health of the aquatic environment. Steps to derive the viability analysis were as follows: (1) establishing meaningful baseline metrics, (2) identifying information deficiencies, and (3) placing the context of current conditions into a usable format for managers and practitioners. Most geographic segments were designated in overall fair condition, and the conservation targets were designated in either good or fair condition, based on available assessed indicators. Many indicators were unable to be assessed or assigned condition status, which identified research and monitoring data gaps. Metrics associated with native migratory fishes, Lake St. Clair, and islands are generally in better condition than metrics associated with the coastal terrestrial systems, aerial migrants, and coastal wetlands. These results were not unexpected given the highly urbanized landscape of the St. Clair-Detroit River System. Resource

\footnotetext{
${ }^{1}$ University of Toledo, Department of Environmental Sciences, Lake Erie Center, 6200 Bayshore Road, Oregon, Ohio 43616.

${ }^{2}$ U.S. Geological Survey, Great Lakes Science Center, 1451 Green Road, Ann Arbor, Michigan 48105.

${ }^{3}$ U.S. Fish and Wildlife Service, Ashland Fish and Wildlife Conservation Office, 2800 Lakeshore Drive East, Ashland, Wisconsin 54806.
}

managers in the corridor can use these results to identify knowledge gaps, research and restoration priorities, and to assess progress towards meeting restoration goals.

\section{Introduction}

Because of the history and severity of environmental degradation within areas in the Great Lakes Basin (fig. 1), the 1987 U.S.-Canada Great Lakes Water Quality Agreement designated multiple locations as Great Lakes Areas of Concern. Individual locations designated as a Great Lakes Area of Concern had remedial action plans established that outlined impairments within each water body and the resulting loss of ecosystem services to humans, habitat, fish, and wildlife. Governmental and nongovernmental organizations began to articulate strategies and create site-specific action plans to address the environmental degradations identified in the remedial action plans.

The St. Clair-Detroit River System (SCDRS), formerly referred to as the Huron-Erie Corridor, is the waterway corridor within the Great Lakes connecting Lake Huron and Lake Erie (fig. 1). The SCDRS is the major outflow for Lake Huron and the upper Great Lakes and the major source of water for Lake Erie. The SCRDS is comprised of distinct water bodies (north to south): the St. Clair River, Lake St. Clair, and the Detroit River that flows into western Lake Erie (fig. 1). Within the SCDRS, the following four areas are designated as Great Lakes Areas of Concern: (1) the St. Clair River, (2) the Detroit River, (3) the Clinton River, and (4) the Rouge River (the Clinton and Rouge Rivers are tributaries of the corridor) (fig. 1). The SCDRS is also an international border between Michigan, United States, and Ontario, Canada (fig. 1). Land use in the region is highly urbanized and developed (for example, agriculture in rural areas) resulting in the loss and degradation of natural resources, altered landscape features, and reduced ecosystem services within the SCDRS (Hondorp and others, 2014). 


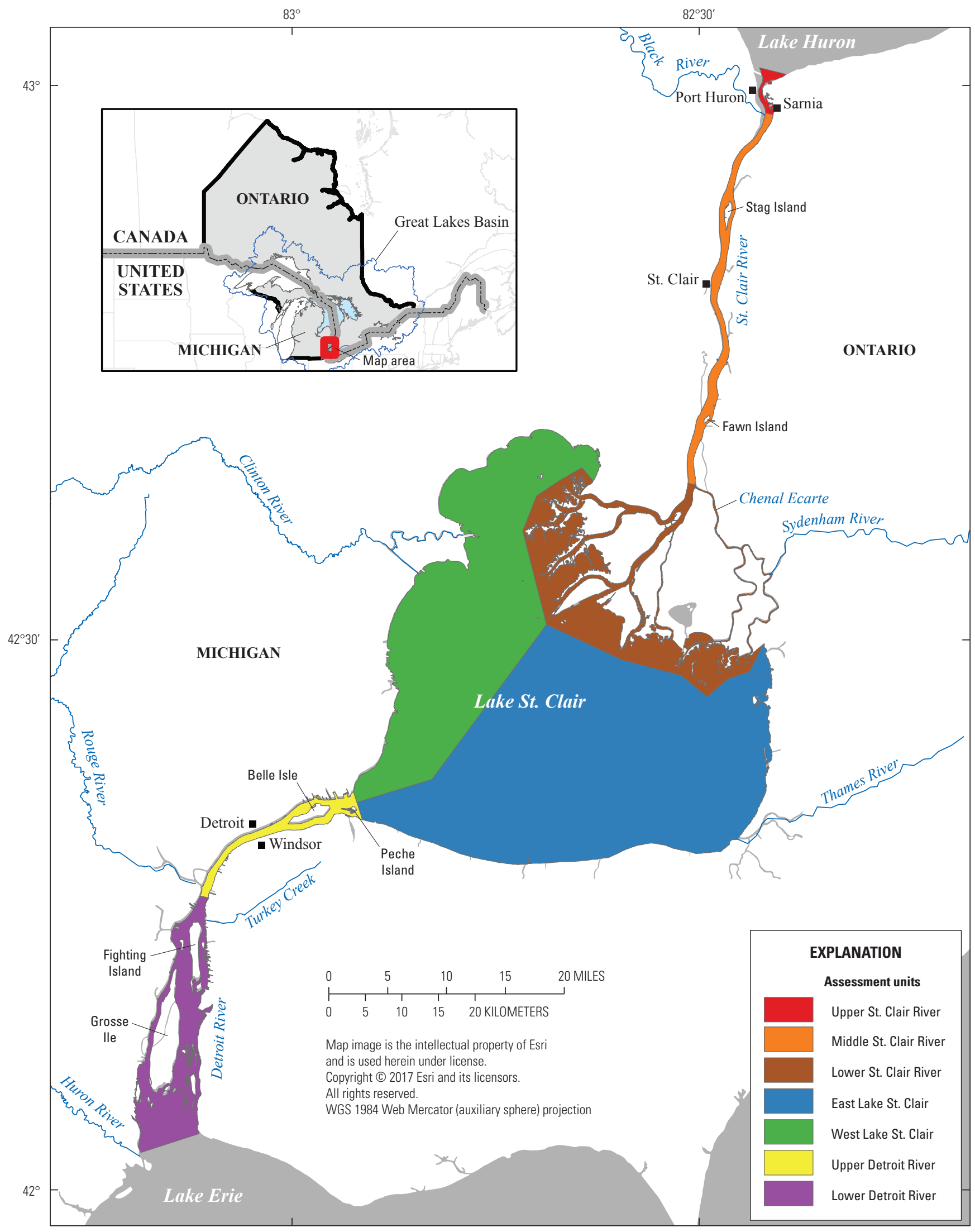

Figure 1. The St. Clair-Detroit River System study area. The St. Clair-Detroit River System is located between the State of Michigan, United States, and the Province of Ontario, Canada. The seven assessment units delineated for this study are displayed. 
In 2004, an international, interdisciplinary, collaborative research and management initiative (known as the HuronErie Corridor Initiative) was formed to develop strategies for implementing innovative research and management efforts in the SCDRS. In 2014, the name was formally changed to the St. Clair-Detroit River System Initiative (SCDRSI; https://scdrs.org/), and the initiative became focused on more than just restoring native fish spawning habitat (Manny and others, 2015). The current (2019) SCDRSI group has representatives from almost every operating tribal, management, and governmental agency within the corridor, as well as nongovernmental organizations, nonprofit organizations, and private consulting firms from the surrounding region. These organizations share a common vision with the goal of restoring the natural structure and function of habitats, populations, and biological communities in the SCDRS. Group membership continues to grow by recruiting new experts and organizations specializing in additional aspects of aquatic resources. The new aspects include water quality, herpetofauna, wildlife, wetlands, and fisheries, as well as a recognition of the significance of socioeconomics in the corridor. This truly holistic approach advocated by the SCDRSI emphasizes the need for a comprehensive contemporary assessment of the environmental conditions within the SCDRS to include identification of environmental threats to accommodate the numerous and, at times, conflicting agency and stakeholder needs.

The current biological and environmental conditions need to be inventoried and assessed within the SCDRS to know where to focus conservation, restoration, and preservation efforts. The Nature Conservancy uses a viability analysis framework as an objective, foundational step for the conservation action planning process that details the existing conditions within the study area regarding the "health" of a population of plant or animal species, habitat attribute (for example, spawning or nursery areas), or other environmental characteristics (The Nature Conservancy, 2007; Foundations of Success, 2009). Accurate assessments of environmental conditions are essential for establishing conservation goals. Conservation targets (environmental aspects to conserve, such as a habitat type or species group) were selected and related key ecological attributes (KEA; measurable aspects of the target's biology or ecology that are known to be essential for survival) were identified to track the attributes' responses to management actions (The Nature Conservancy, 2007; Foundations of Success, 2009). Specific metrics (that is, indicators) were also chosen to assess the status for each of the KEA and track environmental improvements with time.

The objective of this study was to present a comprehensive, contemporary viability analysis for the SCDRS to assist ongoing conservation, preservation, restoration, and remediation efforts. A contemporary inventory of the status of all conservation targets, incorporating data and information from relevant assessments and habitat plans for the region, will help identify gaps in basic knowledge throughout the corridor and provide guidance to ongoing and future conservation and management plans. The results will be used to guide and inform future research, monitoring strategies, and management and conservation planning, particularly informing SCDRSI efforts, throughout the corridor. This information will be accessible for all planners, researchers, and managers for future conservation planning in the SCDRS.

\section{Methods}

To provide a rapid contemporary assessment, the authors of this report built upon other work done within the SCDRS regarding target areas and species, data compilation, and implementation strategies. One key conservation plan completed in 2012, which included the SCDRS, was the Lake Erie Biodiversity Conservation Strategy (LEBCS) (Pearsall and others, 2012). The LEBCS was a large-scale plan developed through the conservation action planning process that delineated conservation targets, KEA, and indicators to align with other Lake Erie plans, specifically the Lake Erie Lakewide Action and Management Plan (Lake Erie Lakewide Action and Management Plan, 2008). By selecting attributes and metrics previously incorporated in the Lake Erie Lakewide Action and Management Plan, the opportunity existed for recommendations and conservation actions in the LEBCS to be implemented on a lakewide scale, with multiple agencies and organizations working together. Similarly, by having this study incorporate many aspects of the LEBCS, the results may further inform and refine planning efforts through the LEBCS and the Lake Erie Lakewide Action and Management Plan. For the selection of indicators for the viability analysis, other local conservation plans and strategies reviewed and considered included the Essex Region Biodiversity Conservation Strategy (Essex Region Conservation Authority, 2002); the Fish-Community Goal and Objectives for Lake St. Clair, St. Clair River, and Detroit River (MacLennan and others, 2003); and the Lake St. Clair Coastal Habitat Assessment (Great Lakes Commission, 2006). The St. Marys River (not shown) is another Great Lakes Area of Concern and connecting channel (between Lake Superior and Lake Huron) where a conservation action plan was completed (St. Marys River Conservation Action Plan) (Harris and others, 2009). Additional appropriate targets, KEA, and indicator metrics from the St. Marys River Conservation Action Plan were incorporated into the SCDRS viability analysis. Modifications to this initial compilation of targets, KEA, and indicator metrics were made based on solicited input from members of the SCDRSI.

\section{Segments of the St. Clair-Detroit River System}

For this study, the geographical scope includes the St. Clair River, Lake St. Clair, and Detroit River (fig. 1); these waters were divided into smaller-scale areas for finer resolution. The LEBCS only divided the SCDRS into three geographic sections-St. Clair River, Lake St. Clair (including the St. Clair River Delta region), and Detroit River. Although 
the three geographic sections may be an appropriate spatial scale for the conservation strategy addressing the Lake Erie Basin (not shown), the scale is not ideal for localized action within the corridor. Therefore, the corridor was divided into finer-scale geographic segments that were generally uniform with respect to landscape features and influences (that is, hydrology, geomorphology, engineering, and ecology [Wang and others, 2006]) to the system. The geographic scope encompassed the head of the St. Clair River downstream to the mouth of Detroit River, ending just north of the confluence of the Huron River and western Lake Erie (fig. 1). Multiple other conservation plans have been developed or are in development for the western basin of Lake Erie; therefore, to avoid duplicating efforts, the viability analysis for this study did not include western Lake Erie. For this analysis, seven unique segments were identified within the SCDRS-St. Clair River (upper, middle, and lower reaches), Lake St. Clair (east and west basins), and Detroit River (upper and lower reaches) (fig. 1). No dams or navigational locks exist within the SCDRS to manipulate flow; however, the corridor is maintained as a navigational channel by a series of dikes and dredged channels, with multiple maintained navigation channels in parts of the Detroit River that alter the flow of water through the corridor (Bennion and Manny, 2011).

The upper St. Clair River segment begins where southern Lake Huron narrows to form the St. Clair River (north of Port Huron, Michigan/Sarnia, Ontario) and ends at the confluence of the first tributary, the Black River, Mich. (fig. 1). Although the upper St. Clair River segment is small (approximately 4 river kilometers $[\mathrm{km}]$ ), the area is substantially different from the remainder of the St. Clair River to justify separation. The upper St. Clair River has the fastest water velocity of the three St. Clair River reaches, and the river characteristics (depth, flow, and river bends) are more variable compared with the more uniform middle St. Clair River reach (Liu and others, 2010). Almost the entire upper St. Clair River section is considered significant fish spawning grounds (Goodyear and others, 1982) and has the largest spawning population of the threatened lake sturgeon (Acipenser fulvescens) in Michigan (Hayes and Caroffino, 2012). The middle St. Clair River segment begins at the Black River, Mich., and ends at the Chenal Ecarte, Ontario (the first distributary of the St. Clair River) (fig. 1). The segment is uniform throughout, interrupted by two islands (Stag and Fawn Islands) and shoals near St. Clair, Mich. (Edsall and others, 1988). The lower St. Clair River segment begins with the Chenal Ecarte, Ontario, and ends at the mouth of the various channels where the distributaries flow into Lake St. Clair. The lower St. Clair River segment comprises the largest freshwater delta in the world (Bolsenga and Herdendorf, 1993). Fish spawning and nursery areas throughout the delta and wetlands are of conservation and restoration priority (Great Lakes Commission, 2006).

Lake St. Clair is the only lake considered in this viability analysis and is divided into two segments based on the two distinct lake basins - west (United States side) and east
(Canadian side). These basins are distinct with respect to the land use, tributary input, and water current circulation patterns (Bolsenga and Herdendorf, 1993; Hondorp and others, 2014) and, therefore, were assessed separately. These segments begin at the end of the delta and extend to the outlet of Lake St. Clair prior to Peche Island in the Detroit River (fig. 1). The St. Clair River contributes 98 percent of the water to Lake St. Clair and the Clinton River (Great Lakes Areas of Concern), Sydenham River, and Thames River contribute the remaining 2 percent (Edsall and others, 1988) (fig. 1).

Approximately 95 percent of the water entering the Detroit River originates from Lake Huron through the St. Clair River-Lake St. Clair system. The upper Detroit River segment begins at Peche Island and continues downstream past the Rouge River outlet, but prior to Turkey Creek, Ontario, just north of Fighting Island (fig. 1). The upper Detroit River is primarily a navigational channel with small areas of nondredged river bottom, including areas around the two islands in this segment, Belle Isle and Peche Island (fig. 1). The lower Detroit River has gently sloping banks, variable river width (approximately $6 \mathrm{~km}$ at mouth), and many islands; the largest being Grosse Ile (fig. 1). Multiple navigational channels are maintained by dredging around the various islands and through reef areas within the lower Detroit River.

\section{Conservation Targets in the St. Clair-Detroit River System}

The goal of this effort was to provide a more detailed finer-scale resolution assessment of the conditions in the SCDRS and complement the similar ongoing conservation planning efforts in the Lake Erie Basin. Therefore, initial conservation targets and KEA were based on relevant biodiversity targets identified in the LEBCS and St. Marys River Conservation Action Plan. This initial list of potential targets was distributed to SCDRSI partners for input and feedback. Additional targets and KEA identified by SCDRSI partners or SCDRS-specific reports or habitat plans were included in the viability analysis as appropriate. Full descriptions of the targets, KEA, and indicators are in appendix 1.

The seven conservation targets assessed for each applicable segment were main channels, Lake St. Clair, native migratory fishes, islands, coastal wetlands, coastal terrestrial systems, and aerial migrants. The main channels target encompassed the lotic habitats within the waters of the St. Clair and Detroit Rivers, which are inhabited by many riverine species and provide habitat used for spawning and migration routes for many large, native migratory fishes in the central Great Lakes (including species assessed in the native migratory fishes target), with larvae drifting downstream to available wetland nursery habitat in Lake St. Clair or Lake Erie (Goodyear and others, 1982). Lake St. Clair is the only large area of lentic habitat in the SCDRS and contains a valuable fishery for multiple warm-water species, such as yellow perch (Perca flavescens), walleye (Sander vitreus), smallmouth bass 
(Micropterus dolomieu), and muskellunge (Esox masquinongy) (Thomas and Wills, 2013). The native migratory fishes target assesses the population levels of fishes that migrate into the SCDRS or its tributaries to complete their life cycle (typically spawning), as well as the habitat required by the various species. The islands target assesses the condition of the islands in the system, natural and artificial. Coastal wetlands for this assessment are defined as areas that are permanently or periodically inundated with water and having vegetation requiring saturated soils that are hydrologically connected to the Great Lakes. Coastal wetlands provide habitat for a diverse group of species (plants and animals) as well as ecosystem services to humans through improving water quality, flood control, and shoreline protection. Coastal wetlands also provide habitat for multiple fish and bird species and provide areas suitable for bird watching, hunting, and fishing. Coastal terrestrial systems considered the terrestrial environments $0-10 \mathrm{~km}$ inland from shore. This distance was chosen in recognition of the influence land use/land cover practices have on the aquatic environment, as well as to align with criteria applied in the LEBCS. Aerial migrants include all types of birds (shorebirds, landbirds, and waterfowl) and other species (insects and butterflies) that use the SCDRS as a pathway during spring and fall migration. The birds use the open water, the islands and wetlands, and the terrestrial areas along the corridor that may be developed.

To determine viability of the targets, KEA and associated indicators were selected from relevant previous plans, input from SCDRSI partners, experts, and literature review. The same KEA and indicators were used to assess multiple conservation targets where appropriate. Useful indicator metrics are measurable, precise, consistent, and sensitive (The Nature Conservancy, 2007). Each indicator (for each applicable segment) was assigned a status value associated with the current condition of the specified indicator when possible. Quantitative values assigned were based on recent (less than 10 years old) assessments gained through direct data collection, literature review, and expert contributions of recent monitoring program results. The status ratings (that is, "health" of the indicators) were classified as very good, good, fair, or poor condition (table 1; ranges for specific indicators in appendix 1) and were based on values from previous conservation plans, expert opinion, and literature review. Overall target condition was determined by the point system described in table 1 (from Pearsall and others, 2012).

\section{Results}

All segments were determined to be in overall fair condition, except the lower St. Clair River, which was in overall good condition (table 2). Most individual target evaluations in the SCDRS assessment units were classified in fair condition. The only poor conditions were for coastal terrestrial systems and aerial migrants in the upper St. Clair River, eastern Lake St. Clair, and upper Detroit River. The lower St. Clair River, western Lake St. Clair, and lower Detroit River had targets (native migratory fishes or islands) classified in very good condition.

Table 1. Target indicator ratings and corresponding rating descriptions used for the St. Clair-Detroit River System viability assessment. Points assigned to specific indicators (based on indicator rating) and KEA/target ranges were used to determine target and assessment unit overall condition. Indicator ratings were averaged for KEA condition and for target conditions (Pearsall and others, 2012, adapted from The Nature Conservancy, 2007).

[KEA, key ecological attributes; NA, not applicable; - , no data]

\begin{tabular}{|c|c|c|c|}
\hline Indicator rating & Description & $\begin{array}{l}\text { Points assigned to } \\
\text { indicators }\end{array}$ & $\mathrm{KEA} /$ target range \\
\hline Very good & $\begin{array}{l}\text { The indicator is functioning at an ecologically desirable status } \\
\text { and requires little human intervention. }\end{array}$ & 4.0 & $3.75-4.0$ \\
\hline Good & $\begin{array}{l}\text { The indicator is functioning within its acceptable range of varia- } \\
\text { tion, but may require some human intervention. }\end{array}$ & 3.5 & $3.0-3.745$ \\
\hline Fair & $\begin{array}{l}\text { The indicator lies outside its acceptable range of variation and } \\
\text { requires human intervention. If unchecked, the target will be } \\
\text { vulnerable to serious degradation. }\end{array}$ & 2.5 & $1.75-2.995$ \\
\hline Poor & $\begin{array}{l}\text { Allowing the indicator to remain in this condition for an extended } \\
\text { period will make restoration or preventing extirpation practi- } \\
\text { cally impossible. }\end{array}$ & 1.0 & $1-1.745$ \\
\hline NA & Target or indicator was not applicable in the specific segment & - & - \\
\hline
\end{tabular}


Table 2. Viability analysis results for the overall condition of the seven conservation targets assessed in each of the assessment units.

[Color designations and explanation of target range values are listed in table 1. Specific target assessments and indicator details are listed in tables 3-7 and appendix 1. Dark green indicates a rating of very good, light green indicates a rating of good, yellow indicates a rating of fair, red indicates a rating of poor, and grey indicates not applicable. SCDRS, St. Clair-Detroit River System; USCR, upper St. Clair River; MSCR, middle St. Clair River; LSCR, lower St. Clair River; WLSC, western Lake St. Clair; ELSC, eastern Lake St. Clair; UDR, upper Detroit River; LDR, lower Detroit River; —, not assessed]

\begin{tabular}{|c|c|c|c|c|c|c|c|}
\hline \multirow{2}{*}{ Conservation target } & \multicolumn{7}{|c|}{ SCDRS assessment unit } \\
\hline & USCR & MSCR & LSCR & WLSC & ELSC & UDR & LDR \\
\hline Main channels & 2.533 & 2.583 & 3.167 & - & - & 2.031 & 2.333 \\
\hline Native migratory fishes & - & 2.833 & 4 & 2.875 & 3.25 & 2.5 & 4 \\
\hline Islands & - & 2.5 & 3.15 & 4 & 2.5 & 2.2 & 1.8 \\
\hline Aerial migrants & 1.417 & 2.278 & 2.944 & 1.944 & 2.583 & 1.25 & 2.194 \\
\hline Overall segment condition & 2.106 & 2.505 & 3.065 & 2.861 & 2.451 & 1.886 & 2.372 \\
\hline
\end{tabular}

\section{Conservation Target-Main Channels}

For the main channels, 29 of the 81 indicators were fully assessed and ranged in status from poor to very good (table 3), resulting in the target being classified overall in fair condition. An additional 15 indicators were assessed but no condition status was assigned because indicator status range thresholds have not been defined. The artificial shoreline hardening index indicator was rated as poor in four out of five segments examined. Nutrient related indicators (KEA — water quality) were rated as good or very good. Because of data gaps, 37 indicators (46 percent) were not assessed for the main channels.

\section{Conservation Target—Lake St. Clair}

For the two Lake St. Clair segments, 10 of the 46 indicators were fully assessed and ranged in status from poor to very good (table 4), resulting in the target being classified overall in good condition. An additional 12 indicators were assessed but no condition status was assigned; many of the indicators were fisheries-related indicators. Indicators associated with watershed development (KEA — coastal and watershed contribution) were determined to be in poor or fair condition. Because of data gaps, 24 indicators (54 percent) were not assessed in Lake St. Clair.

\section{Conservation Target-Native Migratory Fishes}

For native migratory fishes, 20 of the 61 total indicators fully assessed and ranged in status from fair to very good condition (table 5), resulting in the target being classified overall in good condition. An additional 15 indicators were assessed but no condition status was assigned. All indicators with an assigned condition status measured fishes' accessibility of tributary river and stream waters (KEA - access to spawning areas). Because of data gaps, 26 indicators (43 percent) were not assessed for native migratory fishes.

\section{Conservation Target-Islands}

For islands, all of the 36 indicators were fully assessed and ranged in status from poor to very good condition (table 5), resulting in the target being classified overall in fair condition. Although by number, most of the islands in the SCDRS are undeveloped, resulting in many indicators being classified in very good condition in multiple segments; many islands were developed in varying degrees. Grosse Ile and Belle Isle in the Detroit River are two large, developed islands that resulted in the upper and lower Detroit River segments having a status of poor for road and housing density and for artificial shoreline hardening. Also, most of the islands are not protected in the SCDRS (KEA - conservation status), resulting in a poor status assignment.

\section{Conservation Target-Coastal Wetlands}

For coastal wetlands, 46 of the 98 total indicators were fully assessed and ranged in status from poor to good (table 6), resulting in the target being classified overall in fair condition. An additional three indicators were assessed but no condition status was assigned. Of the indicators that were fully assessed, indicators measuring habitat connectivity were often assigned fair or poor statuses, and indicators for various biota varied in status among the segments. Because of data gaps, 49 indicators ( 50 percent) were not assessed for coastal wetlands. 
Table 3. Viability analysis results for the main channels target.

[Detailed descriptions of indicators, specific indicator assessment approaches and data sources, and indicator rating thresholds are listed in appendix 1. Dark green indicates a rating of very good, light green indicates a rating of good, yellow indicates a rating of fair, red indicates a rating of poor, and grey indicates not applicable. Cells with assessment values but no color, indicate no indicator rating thresholds assigned for that indicator and segment. SCDRS, St. Clair-Detroit River System; USCR, upper St. Clair River; MSCR, middle St. Clair River; LSCR, lower St. Clair River; UDR, upper Detroit River; LDR, lower Detroit River; $\%$, percent; - , not assessed; $\mathrm{m}^{3}$, cubic meter; $\mathrm{m}$, meter; $\mathrm{mg} / \mathrm{L}$, milligrams per liter; $\mu \mathrm{g} / \mathrm{L}$, micrograms per liter; $\mathrm{m}^{2}$, square meter]

\begin{tabular}{|c|c|c|c|c|c|c|}
\hline \multirow{2}{*}{$\begin{array}{l}\text { Key ecological at- } \\
\text { tribute }\end{array}$} & \multirow{2}{*}{ Indicator } & \multicolumn{5}{|c|}{ SCDRS assessment unit } \\
\hline & & USCR & MSCR & LSCR & UDR & LDR \\
\hline Channel condition & Artificial shoreline hardening index & $100 \%$ & $96 \%$ & $30 \%$ & $99 \%$ & $75 \%$ \\
\hline \multirow{2}{*}{$\begin{array}{l}\text { Community archi- } \\
\text { tecture }\end{array}$} & Fish species richness - spawning & - & 11 & 14 & 16 & 11 \\
\hline & Wetland area (acres) & 11 & 84 & 33,520 & 166 & 3,934 \\
\hline \multirow[t]{2}{*}{ Fish tissue } & Contaminant load-mercury & - & - & - & - & - \\
\hline & $\begin{array}{l}\text { Contaminant load-polychlorinated } \\
\text { biphenyls }\end{array}$ & - & - & - & - & - \\
\hline \multirow[t]{5}{*}{ Water quality } & $\begin{array}{l}\text { Mean Hexagenia densities in fine } \\
\text { sediments }\end{array}$ & - & - & - & - & - \\
\hline & Mean Mar.-Oct. water levels (m) & 176.0 & 175.5 & 175.2 & 174.8 & 174.4 \\
\hline & $\begin{array}{l}\text { Mean (median) total dissolved solids } \\
\quad(\mathrm{mg} / \mathrm{L})\end{array}$ & $134(140)$ & $144(145)$ & - & $164(150)$ & $151(150)$ \\
\hline & $\begin{array}{l}\text { Mean (median) total phosphorus } \\
\quad(\mu \mathrm{g} / \mathrm{L})\end{array}$ & $3.67(2.0)$ & $1.67(4.0)$ & - & $6.33(10.0)$ & $7.33(9.0)$ \\
\hline & $\begin{array}{l}\% \text { of beaches open during } E \text {. coli } \\
\text { monitoring }\end{array}$ & - & $100 \%$ & - & $100 \%$ & - \\
\hline
\end{tabular}

\section{Conservation Target—Coastal Terrestrial Systems}

For coastal terrestrial systems, 41 of the 42 total indicators were fully assessed and ranged in status from poor to very good (table 7), resulting in the target being classified overall in fair condition. The coastal terrestrial system indicators surrounding most of the SCDRS are ranked in poor condition
(59 percent of indicators), reflecting the high level of development in this urban and suburban area. The lower St. Clair River segment had a higher proportion of natural land cover close to the shore and less hardened shorelines because of the large number of uninhabited islands comprising the delta. Only one indicator ( 2 percent) was not assessed for coastal terrestrial systems. 
Table 4. Viability analysis results for Lake St. Clair target.

[Detailed descriptions of indicators, specific indicator assessment approaches and data sources, and indicator rating thresholds are listed in appendix 1. Dark green indicates a rating of very good, light green indicates a rating of good, yellow indicates a rating of fair, red indicates a rating of poor, and grey indicates not applicable. Cells with assessment values but no color, indicate no indicator rating thresholds assigned for that indicator and segment. SCDRS, St. Clair-Detroit River System; WLSC, western Lake St. Clair; ELSC, eastern Lake St. Clair; —, not assessed; $\mathrm{m}^{2}$, square meter; km, kilometer; \%, percent; >, greater than; $\mu \mathrm{g} / \mathrm{L}$, micrograms per liter; gDW/m², grams dry weight per square meter; L, liter]

\begin{tabular}{|c|c|c|c|}
\hline \multirow{2}{*}{ Key ecological attribute } & \multirow{2}{*}{ Indicator } & \multicolumn{2}{|c|}{ SCDRS assessment unit } \\
\hline & & WLSC & ELSC \\
\hline \multirow[t]{4}{*}{ Community architecture } & $\begin{array}{l}\text { 3-year mean total native intolerant fish species in annual } \\
\text { bottom trawl surveys }\end{array}$ & 7 & - \\
\hline & Mean Dreissena density (number per $\mathrm{m}^{2}$ ) & - & - \\
\hline & Smallmouth bass population (number per lift) & 4.01 & 0.23 \\
\hline & Muskellunge population (number per lift) & 0.00 & 0.17 \\
\hline \multirow{2}{*}{$\begin{array}{l}\text { Soil/sediment stability and } \\
\text { movement }\end{array}$} & Bed load traps and groins (number per $100 \mathrm{~km}$ of shoreline) & 10.3 & 18.1 \\
\hline & Erosion and deposition rates (from tributaries) & - & - \\
\hline $\begin{array}{l}\text { Landscape pattern and } \\
\text { structure }\end{array}$ & $\begin{array}{l}\text { Emergent and submergent vegetation distribution in protected } \\
\text { embayments and soft sediment areas }\end{array}$ & $>50 \%$ & $>50 \%$ \\
\hline \multirow[t]{5}{*}{ Water quality } & Dissolved phosphorus load & - & - \\
\hline & Nitrogen & - & - \\
\hline & Total phosphorus concentrations $(\mu \mathrm{g} / \mathrm{L})$ & 11.75 & - \\
\hline & $\begin{array}{l}\text { Cladophora standing crop }\left(\mathrm{gDW} / \mathrm{m}^{2}\right) \text { during late summer } \\
\text { (Aug.-Sept.) }\end{array}$ & - & - \\
\hline & Contaminants mercury (walleye) & - & - \\
\hline \multirow[t]{2}{*}{ Food web linkages } & Mean Hexagenia density in fine sediments & - & - \\
\hline & $\begin{array}{l}\text { Mean densities of rotifers, copepods, and cladocerans in early } \\
\text { summer (number per L) }\end{array}$ & $-/ 0.79 / 0.50$ & - \\
\hline
\end{tabular}


Table 5. Viability analysis results for native migratory fishes and islands targets.

[Detailed descriptions of indicators, specific indicator assessment approaches and data sources, and indicator rating thresholds are listed in appendix 1. Dark green indicates a rating of very good, light green indicates a rating of good, yellow indicates a rating of fair, red indicates a rating of poor, and grey indicates not applicable. Cells with assessment values but no color, indicate no indicator rating thresholds assigned for that indicator and segment. SCDRS, St. Clair-Detroit River System; USCR, upper St. Clair River; MSCR, middle St. Clair River; LSCR, lower St. Clair River; WLSC, western Lake St. Clair; ELSC, eastern Lake St. Clair; UDR, upper Detroit River; LDR, lower Detroit River; \%, percent; SO, stream order; —, not assessed; ha, hectares; m, meter; km², square kilometer; $\mathrm{km}$, kilometer]

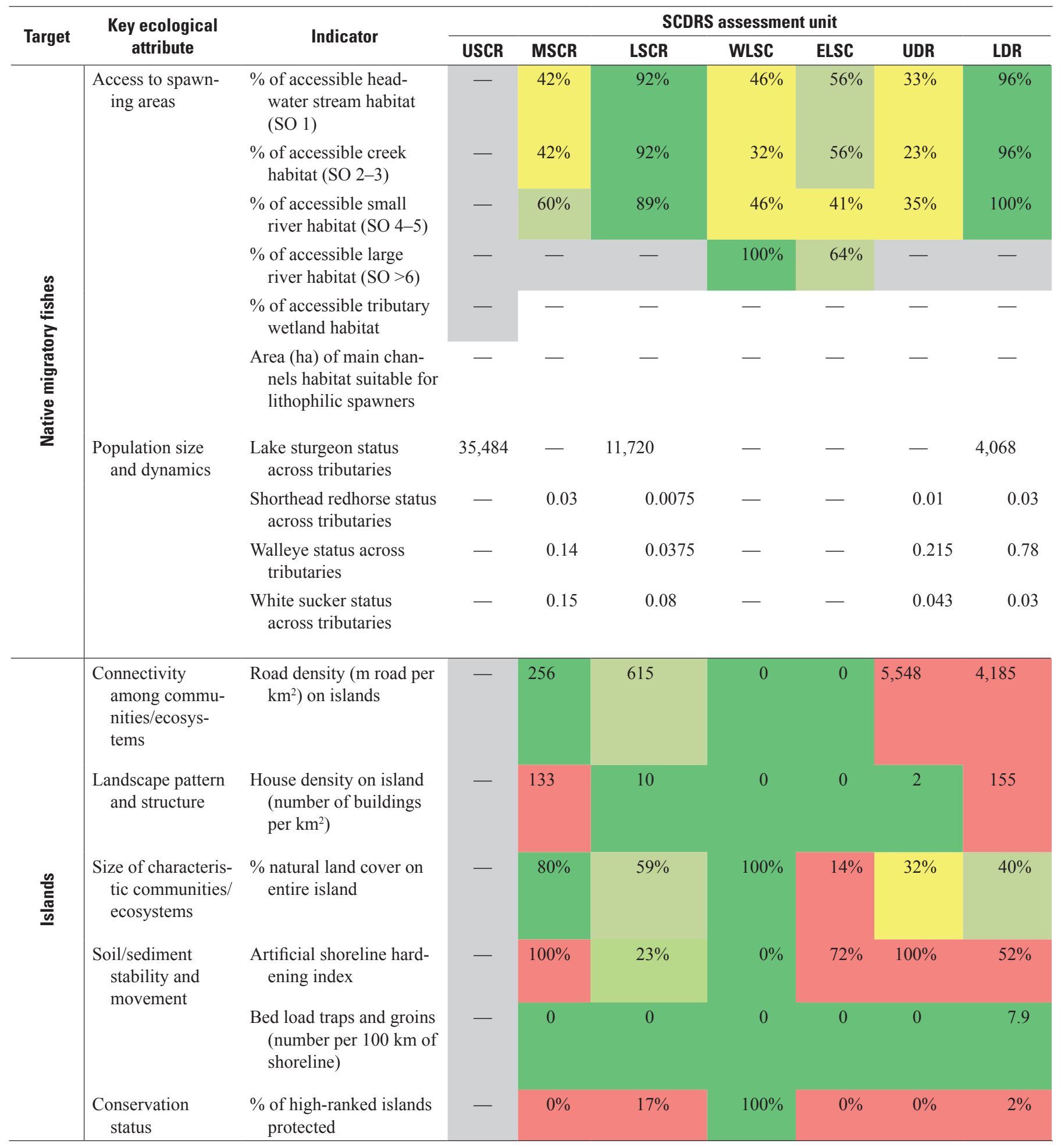


Table 6. Viability analysis results for coastal wetlands.

[Detailed descriptions of indicators, specific indicator assessment approaches and data sources, and indicator rating thresholds are listed in appendix 1. Dark green indicates a rating of very good, light green indicates a rating of good, yellow indicates a rating of fair, red indicates a rating of poor, and grey indicates not applicable. Cells with assessment values but no color, indicate no indicator rating thresholds assigned for that indicator and segment. SCDRS, St. Clair-Detroit River System; USCR, upper St. Clair River; MSCR, middle St. Clair River; LSCR, lower St. Clair River; WLSC, western Lake St. Clair; ELSC, eastern Lake St. Clair; UDR, upper Detroit River; LDR, lower Detroit River; IBI, index of biotic integrity; —, not assessed; \%, percent]

\begin{tabular}{|c|c|c|c|c|c|c|c|c|}
\hline \multirow{2}{*}{ Key ecological attribute } & \multirow{2}{*}{ Indicator } & \multicolumn{7}{|c|}{ SCDRS assessment unit } \\
\hline & & USCR & MSCR & LSCR & WLSC & ELSC & UDR & LDR \\
\hline $\begin{array}{l}\text { Abundance and diversity } \\
\text { of amphibians }\end{array}$ & $\begin{array}{l}\text { Amphibian community- } \\
\text { based coastal wetland } \\
\text { IBI }\end{array}$ & 53 & - & 39 & - & 23 & 2 & 25 \\
\hline $\begin{array}{l}\text { Abundance and diversity } \\
\text { of wetland-dependent } \\
\text { bird species }\end{array}$ & Marsh bird IBI & - & - & 37 & 49 & 44 & 9 & 26 \\
\hline Fish habitat quality & $\begin{array}{l}\text { Wetland fish index of } \\
\text { wetland quality }\end{array}$ & - & - & - & - & - & - & - \\
\hline $\begin{array}{l}\text { Macroinvertebrate } \\
\text { quality }\end{array}$ & Invertebrate IBI & - & 36 & 42 & - & 48.3 & - & - \\
\hline $\begin{array}{l}\text { Species composition/ } \\
\text { dominance }\end{array}$ & $\begin{array}{l}\text { Wetland macrophyte } \\
\text { index }\end{array}$ & - & 3 & 3 & - & - & 3 & 3 \\
\hline $\begin{array}{l}\text { Spawning habitat quality } \\
\text { and accessibility }\end{array}$ & $\begin{array}{c}\text { Spawning/recruitment } \\
\text { success of coastal } \\
\text { wetland spawners }\end{array}$ & - & - & - & - & - & - & - \\
\hline Trophic structure & $\begin{array}{l}\text { Wetland zooplankton } \\
\text { index }\end{array}$ & - & - & - & - & - & - & - \\
\hline $\begin{array}{l}\text { Connectivity among } \\
\text { communities and } \\
\text { ecosystems }\end{array}$ & $\begin{array}{l}\text { Percent natural land } \\
\text { cover in watershed }\end{array}$ & $3 \%$ & $29 \%$ & $13 \%$ & $28 \%$ & $9 \%$ & $17 \%$ & $13 \%$ \\
\hline \multirow[t]{2}{*}{ Water quality } & $\begin{array}{l}\text { Mean annual total phos- } \\
\text { phorus }\end{array}$ & - & - & - & - & - & - & - \\
\hline & $\begin{array}{l}\text { Water Quality Index for } \\
\text { wetland quality }\end{array}$ & - & - & 一 & - & - & - & - \\
\hline $\begin{array}{l}\text { Size of characteristic } \\
\text { communities /ecosys- } \\
\text { tems }\end{array}$ & Wetland area (acres) & 11 & 84 & 33,520 & 1,108 & 4,482 & 166 & 3,934 \\
\hline
\end{tabular}




\section{Conservation Target—Aerial Migrants}

For aerial migrants, all 42 indicators were fully assessed and ranged in status from poor to very good (table 7), resulting in the target being classified overall in fair condition. More indicators were classified as poor for shorebird indicators than for the landbird and waterfowl indicators. The lower St. Clair River and eastern Lake St. Clair segments contained more indicators in very good condition than the other segments. The percent of land in conservation management was poor for all segments; however, this indicator was calculated considering only the U.S. side of the segments.

Table 7. Viability analysis results for coastal terrestrial systems and aerial migrants.

[Detailed descriptions of indicators, specific indicator assessment approaches and data sources, and indicator rating thresholds are listed in appendix 1. Dark green indicates a rating of very good, light green indicates a rating of good, yellow indicates a rating of fair, red indicates a rating of poor, and grey indicates not applicable. Cells with assessment values but no color, indicate no indicator rating thresholds assigned for that indicator and segment. SCDRS, St. Clair-Detroit River System; USCR, upper St. Clair River; MSCR, middle St. Clair River; LSCR, lower St. Clair River; WLSC, western Lake St. Clair; ELSC, eastern Lake St. Clair; UDR, upper Detroit River; LDR, lower Detroit River; m, meter; km², square kilometer; km, kilometer; \%, percent; —, not assessed]

\begin{tabular}{|c|c|c|c|c|c|c|c|c|c|}
\hline \multirow{2}{*}{ Target } & \multirow{2}{*}{$\begin{array}{l}\text { Key ecological } \\
\text { attribute }\end{array}$} & \multirow{2}{*}{ Indicator } & \multicolumn{7}{|c|}{ SCDRS assessment units } \\
\hline & & & USCR & MSCR & LSCR & WLSC & ELSC & UDR & LDR \\
\hline \multirow{4}{*}{ 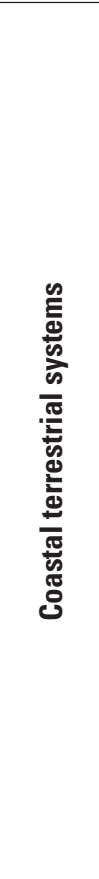 } & $\begin{array}{l}\text { Connectivity } \\
\text { among com- } \\
\text { munities and } \\
\text { ecosystems }\end{array}$ & $\begin{array}{l}\text { Road density ( } \mathrm{m} \text { road per } \\
\mathrm{km}^{2} \text { ) within } 2 \mathrm{~km} \text { of } \\
\text { shoreline }\end{array}$ & 13,226 & 3,652 & 1,132 & 7,543 & 2,854 & 11,280 & 5,987 \\
\hline & $\begin{array}{l}\text { Size/extent of } \\
\text { characteristic } \\
\text { communities/ } \\
\text { ecosystems }\end{array}$ & $\begin{array}{l}\% \text { natural land cover within } \\
2 \mathrm{~km} \text { of shoreline }\end{array}$ & $5 \%$ & $24 \%$ & $51 \%$ & $23 \%$ & $8 \%$ & $4 \%$ & $51 \%$ \\
\hline & movement & $\begin{array}{l}\text { Bed load traps and groins } \\
\text { (number per } 100 \mathrm{~km} \text { of } \\
\text { shoreline) }\end{array}$ & 0 & 3.8 & 0.3 & 10.3 & 18.1 & 3.6 & 16.2 \\
\hline & Coastal land use & $\begin{array}{l}\% \text { area } 2-10 \mathrm{~km} \text { from lake } \\
\text { in natural land cover }\end{array}$ & $26 \%$ & $30 \%$ & $8 \%$ & $22 \%$ & $2 \%$ & $2 \%$ & $11 \%$ \\
\hline \multirow{4}{*}{ 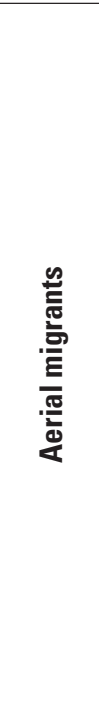 } & $\begin{array}{l}\text { Anthropogenic } \\
\text { disturbance }\end{array}$ & $\begin{array}{l}\text { Mean distance between suit- } \\
\text { able shorebird habitat and } \\
\text { disturbance factor }(\mathrm{m})\end{array}$ & 39 & 227 & 914 & 91 & 233 & 58 & 198 \\
\hline & & $\begin{array}{l}\text { Mean distance between suit- } \\
\text { able waterfowl habitat and } \\
\text { disturbance factor }(\mathrm{m})\end{array}$ & 126 & 237 & 1,752 & 1,081 & 1,129 & 121 & 473 \\
\hline & & $\begin{array}{c}\% \text { of } 2 \mathrm{~km} \text { shoreline area } \\
\text { suitable for waterfowl }\end{array}$ & $17 \%$ & $45 \%$ & $88 \%$ & $56 \%$ & $95 \%$ & $22 \%$ & $54 \%$ \\
\hline & $\begin{array}{l}\text { Management } \\
\text { status }\end{array}$ & $\begin{array}{l}\% \text { of high priority habitat } \\
\text { across all bird groups in } \\
\text { conservation management } \\
\text { (United States only) }\end{array}$ & $0 \%$ & $2 \%$ & $25 \%$ & $34 \%$ & $0 \%$ & $0 \%$ & $11 \%$ \\
\hline
\end{tabular}




\section{Discussion}

Developing a viability analysis for the SCDRS resulted in a straightforward, visual snapshot of the current conditions within the corridor, based on the targets and indicators identified. This viability analysis is a critical first step toward systematic conservation planning based on current and up-todate information (Nel and others, 2009). This viability analysis also underscores where information gaps exist (for example, coastal wetlands and Lake St. Clair) and which indicators need condition status ranges developed (for example, native migratory fishes and Lake St. Clair). Indicators that assessed human impacts through urbanization, contrasted to indicators that strictly assessed in-water biota, were frequently classified in poor condition. However, many indicator measurements assessing biota could not be collected, or status rating thresholds for these indicators had not been developed. If all indicators are fully assessed, the overall target condition could possibly be different; however, even with the current limited assessment, many indicators were identified in poor condition and in need of restoration and remediation efforts.

Compared to the indicators that required field studies, which limited data availability and assessments, most indicators dependent upon geographic information system data were assessed and assigned a status. Data gaps could be due to several reasons; for example, (1) the information has not been collected recently (less than 10 years); (2) a source of the information could not be determined; (3) the data were not in the correct form, or (4) the targeted metrics were not being collected. To minimize possibilities for the first two scenarios, the authors of this report thoroughly searched for literature, searched the internet, and communicated personally with experts to identify sources of contemporary information and data. The authors acknowledge, however, that the methods used may have missed some viable sources. To minimize the third data gap, the indicator was adjusted, when possible, to conform to data already collected, particularly if the data were derived from reoccurring standardized survey (for example, annual fish community surveys led by the Michigan Department of Natural Resources and Ontario Ministry of Natural Resources and Forestry). The remaining data gaps serve to identify deficiencies in assessment data, or data access, and can help guide management efforts to close some information gaps.

In addition, results may not accurately reflect the true conditions because of the limitations of the analysis. For example, most segments of the SCDRS ranked as very good for waterfowl distance to disturbance indicator. However, waterfowl suitable area included all the open water and nearshore area as habitat, but did not include the navigational shipping channels or other heavily used on-water areas as disturbance factors (for example, smaller marked navigational lanes). Therefore, results likely overestimate the area that is undisturbed because of recreational and commercial boat traffic, especially in the lower St. Clair River and Detroit River segments. The Nature Conservancy classified Lake St. Clair and the Detroit River as Important Bird Areas (Henson and others, 2010), indicating that the areas are globally significant for waterfowl and other congregatory species. Future updates to this viability analysis should incorporate the various shipping and navigational lanes to adjust the disturbance potential through these Important Bird Areas.

The authors of this report were able to develop KEA quickly and efficiently as a result of previous planning efforts (for example, Essex Region Conservation Authority [2002], MacLennan and others [2003], Great Lakes Commission [2006], and Pearsall and others, [2012]) and had the explicit goals of dovetailing and integrating efforts with these other plans. The authors were able to fully assess a higher proportion of indicators (using only quantitative measures) than the LEBCS; however, the indicators evaluated were not identical, so the two studies are not 1:1 in scale and specific content. Depending on the size of a study area and the breadth of targets selected, the effort put into selecting conservation targets, KEA, and indicators could be extensive. These previous plans were thorough and developed in close collaboration with professionals in the region, so duplicating these efforts was not warranted. However, verifying that the indicators listed in these plans coordinated with the needs and capabilities of this project was extremely important as adjustments were required for many indicators.

In addition to gathering missing indicator values within the segments, additional considerations derived from this viability analysis can be considered in future conservation plans and strategies. The first consideration is the development of condition status ranges and, ultimately, the desired condition for each indicator. The indicator statuses determined for this study could be considered a baseline, but determining the desired status for all indicators may be difficult given the highly urbanized landscape and irreversibly degraded state for some indicators (for example, housing and road densities). Additionally, the predicted ecosystem changes associated with climate change may not permit significant ecological shifts back to historical conditions, but instead change the ecosystem in ways currently unknown or unpredictable (Burkett and others, 2005; Mackey and others, 2006; Mackey, 2012). The goal for many indicators may be to not further degrade with time, or only move up one indicator rating (for example, from poor to fair) because of the tradeoff among improving indicator status, providing recreational and economic opportunities, and the cost of improving indicators. For example, as people are moved away from the shoreline, indicators improve (such as average distance to disturbance), but citizens' connections with the resources and recreational and economic potential become more limited. Balancing the needs of the SCDRS ecosystem with the desires of the people will include tradeoffs, and a higher-order conservation plan could bring together the various strategies employed by regional conservation planning efforts and focus on priorities that incorporate the high-ranking threats to this system described in Pearsall and others (2012). 
Second, even though tributaries to the SCDRS were not part of this viability analysis (except for tributary accessibility), restoration strategies may need to explicitly consider tributaries and their watersheds because this longitudinal connectivity can influence study area conditions, including KEA and study area metrics. Improvements to the watershed tributaries of the SCDRS will not only improve ecosystem conditions in that direct vicinity (for example, two Great Lakes Areas of Concern - the Clinton and Rouge Rivers), but also in the terminal portion of the SCDRS, western Lake Erie. Benefits will be seen throughout the system, especially for those species that use multiple habitats to complete their life cycle. The migratory fishes that live in Lake Erie, but migrate to the SCDRS to spawn (for example, walleye and lake whitefish), will experience improved spawning and nursery conditions. These conditions could lead to increased adult fish abundances not only in the SCDRS, but also in Lake Erie.

Using the viability analysis as a framework was an efficient and effective tool to rapidly assess the current conditions of the SCDRS for the seven target areas. Small restoration efforts that are not coordinated with other habitat management efforts in an area are not ideal (Hackney, 2000). The viability analysis framework was determined useful to gain a comprehensive assessment of system conditions, aquatic or terrestrial. Importance of quantitatively assessing conditions within the SCDRS to address conservation needs and adapt to climate change has been identified as necessary to moving forward and developing restoration and management strategies (Mackey and others, 2006; Pearsall and others, 2012). This viability analysis has improved on previous assessments and provides a clear picture of where information is still lacking and what targets or segments are in need of restoration efforts. Previous work determined that only sites furthest upstream in the Detroit River, near Peche Island, have indicated signs of fish community recovery despite restoration activities throughout the river (Granados and others, 2014); results from this study also indicate that the Detroit River remains in poor condition with regard to many indicators and continues to require remediation and restoration activities. This framework also facilitated interpretation of results for interdisciplinary collaboration (that is, SCDRSI), as well as for other stakeholders. The increase in understanding of current environmental conditions could serve to increase collaboration among partners on specific projects, as well as help communicate results to the public and increase public awareness and support for local projects. Using identical metrics to measure and track environmental trends across SCDRSI partners is a critical step for a multiagency, multistakeholder collaboration to have a collective impact towards shared goals and objectives (Kania and Kramer, 2011).

Finally, managers and conservation practitioners face many challenges that impede successful ecosystem restoration, especially in urban areas such as the SCDRS. The authors of this report have identified some key challenges from this project, as well as the following steps managers can consider to move forward and improve on the viability analysis framework and on the results.

1. Identify data gaps in the current assessment that can be addressed and completed.

2. Identify common, specific indicator goals that can be established among SCDRSI partners.

3. Develop conservation strategies with pragmatic priorities, actions, and desired outcomes.

4. The viability analysis should be periodically updated to track progress and adapt strategies where needed.

5. Identify sociological and economical aspects and indicators that can be incorporated into the viability analysis as well as in the management of the SCDRS as a whole (Naiman, 2013).

Identifying and prioritizing areas or conservation targets of the SCDRS for improvement can help the SCDRSI partners to work more harmoniously and may improve the ability to take advantage of available funding opportunities to improve environmental conditions within the corridor. Because of the systematic process and framework used, these challenges can be addressed through continued effective cooperation, interjurisdictional collaboration, and commitment of all the SCDRSI partners.

\section{References Cited}

Bennion, D.H., and Manny, B.A., 2011, Construction of shipping channels in the Detroit River-History and environmental consequences: U.S. Geological Survey Scientific Investigations Report 2011-5122, 14 p.

Bolsenga, S.J., and Herdendorf, C.E., 1993, Lake Erie and Lake St. Clair Handbook: Detroit, Mich., Wayne State University Press.

Burkett, V.R., Wilcox, D.A., Stottlemyer, R., Barrow, W., Fagre, D., Baron, J., Price, J., Nielsen, J.L., Allen, C.D., Peterson, D.L., Ruggerone, G., and Doyle, T., 2005, Nonlinear dynamics in ecosystem response to climatic changeCase studies and policy implications: Ecological Complexity, v. 2, p. 357-394.

Edsall, T.A., Manny, B.A., and Raphael, C.D., 1988, The St. Clair River and Lake St. Clair, Michigan-An ecological profile: Ann Arbor, Mich., U.S. Fish and Wildlife Service Biological Report, v. 85, no. 7.3.

Essex Region Conservation Authority, 2002, Essex Region biodiversity conservation strategy-Habitat restoration and enhancement guidelines and priorities: Essex, Ontario, Essex Region Conservation Authority, 181 p. 
Foundations of Success, 2009, Conceptualizing and planning conservation projects and programs-A training manual: Bethesda, Md., Foundations of Success.

Goodyear, C.D., Edsall, T.A., Dempsey, D.M.O., Moss, G.D., and Polanski, P.E., 1982, Atlas of the spawning and nursery areas of Great Lakes fishes, volume XIII-Species reproduction characteristics: Ann Arbor Mich., U.S. Fish and Wildlife Service, FWS/OBS-82/52, 144 p., accessed July 23, 2018, at https://www.glsc.usgs.gov/sites/default/ files/product_files/volume13.pdf.

Granados, M., Mandrak, N.E., and Jackson, D.A., 2014, Synthesizing reference conditions for highly degraded areas through best professional judgment: Journal of Great Lakes Research, v. 40, sup. 2, p. 37-42.

Great Lakes Commission, 2006, Lake St. Clair Coastal Habitat Assessment-With recommendations for conservation and restoration planning: Ann Arbor, Mich., Great Lakes Commission, 231 p., appendixes.

Hackney, C.T., 2000, Restoration of coastal habitats-Expectation and reality: Ecological Engineering, v. 15, no. 3-4, p. $165-170$.

Harris, R., Kinder, B., Marino, A., Patterson, T., and ParkerGeisman, V., 2009, St. Marys River Watershed—Planning for biodiversity conservation: Ann Arbor, Mich., M.S. Thesis, University of Michigan.

Hayes, D.B., and Caroffino, D.C., eds., 2012, Michigan's lake sturgeon rehabilitation strategy: Lansing, Mich., Michigan Department of Natural Resources, Fisheries Division Special Report 62, 18 p.

Henson, B.L., Kraus, D.T., McMurtry, M.J., and Ewert, D.N., 2010, Islands of life-A biodiversity and conservation atlas of the Great Lakes Islands: Toronto, Ontario, Nature Conservancy of Canada.

Hondorp, D.W., Roseman, E.F., and Manny, B.A., 2014,. An ecological basis for future fish habitat restoration efforts in the Huron-Erie Corridor: Journal of Great Lakes Research, v. 40 , p. $23-30$.

Kania, J., and Kramer, M., 2011, Collective impact: Stanford Social Innovation Review 9, p. 36-41.

Lake Erie Lakewide Action Management Plan, 2008, Lake Erie Lakewide Management Plan-2008 update: Prepared by the Lake Erie Lakewide Action and Management Plan Working Group, accessed August 30, 2018, at https://www.epa.gov/sites/production/files/2015-10/ documents/lake-erie-lamp-2008.pdf.

Liu, X., Parker, G., and Garcia, M.H., 2010, Numerical modeling of the St. Clair River and sediment mobility analysis: World Environmental and Water Resources Congress 2010, p. 1412-1420.
Mackey, S.D, 2012, Great Lakes nearshore and coastal systems: In: U.S. National Climate Assessment Midwest Technical Input Report 14, J. Winkler, J. Andresen, J. Hatfield, D. Bidwell, and D. Brown, coordinator, Great Lakes Integrated Sciences and Assessments Center, accessed August 24, 2018, at http://greatlakesresilience.org/sites/default/files/ library_reference_2012_GLISA_CoastalSectorMidWestTec hnicalInputReportNationalClimateAssessment.pdf.

Mackey, S.D.; Reutter, J.M.; Ciborowski, J.J.H.; Haas, R.C.; Charlton, M.N.; and Kreis, R.J., Jr., 2006, HuronErie Corridor system habitat assessment-Changing water levels and effects of global climate change: Project Completion Report, USFWS Restoration Act Sponsored Research Agreement \#30181-4-J259, 47 p., accessed July 23, 2018, at http://web2.uwindsor.ca/lemn/ ResearchNeedsWorkshop302 files/HEC\%20Project $\% 20$ Completion\%20Report\%202006\%20Final.pdf.

MacLennan, D.S., Haas, R.C., Towns, G., Thomas, M.V., Roseman, E., Francis, J., Brauncheidel, J., Halyk, L., Hector, D., Locke, B., McGregor, R., Morencie, M., and Murray, A., 2003, Draft Fish Community Goals and Objectives for Lake St. Clair, St. Clair River, and Detroit River (St. Clair System): Ann Arbor, Mich., Great Lakes Fishery Commission Special Publication Draft, accessed July 25, 2018, at http://www.glfc.org/pubs/lake_committees/erie/ scsfcgo.pdf.

Manny, B.A., Roseman, E.F., Kennedy, G., Boase, J.C., Craig, J.M., Bennion, D.H., Read, J., Vaccaro, L., Chiotti, J., Drouin, R., and Ellison, R., 2015, A scientific basis for restoring fish spawning habitat in the St. Clair and Detroit Rivers of the Laurentian Great Lakes: Restoration Ecology, v. 23 , no. 2 , p. $149-156$.

Naiman, R.J., 2013, Socio-ecological complexity and the restoration of river ecosystems: Inland Waters, v. 3, p. 391-410.

Nel, J.L., Roux, D.J., Abell, R., Ashton, P.J., Cowling, R.M., Higgins, J.V., Thieme, M., and Viers, J.H., 2009, Progress and challenges in freshwater conservation planning: Aquatic Conservation, Marine and Freshwater Ecosystems, v. 19, no. 4 , p. $474-485$.

Pearsall, D., Carton de Grammont, P., Cavalieri, C., Chu, C., Doran, P., Elbing, L., Ewert, D., Hall, K., Herbert, M., Khoury, M., Kraus, D., Mysorekar, S., Paskus, J., and Sasson, A., 2012, Returning to a healthy lake - An international biodiversity conservation strategy for Lake Erie: Lansing, Mich., Technical Report, a joint publication of The Nature Conservancy, Nature Conservancy of Canada, and Michigan Natural Features Inventory, 340 p., appendixes. 
The Nature Conservancy, 2007, Conservation action planning handbook: Developing strategies, taking action and measuring success at any scale: Arlington, Virg., The Nature Conservancy: accessed August 24, 2018, at https://www.conservationgateway.org/Documents/Cap $\% 20$ Handbook_June2007.pdf

Thomas, M.V., and Wills, T., 2013, Status of the fisheries in Michigan waters of Lake Erie and Lake St. Clair, 2012, Prepared for the Great Lakes Fishery Commission Lake Erie Committee: Lansing, Mich., Michigan Department of Natural Resources, accessed August 30, 2018, at https://www.michigan.gov/documents/dnr/ LSCFRS-status-2012_414757_7.pdf.

Wang, L., Seelbach, P.L., and Hughes, R.M., 2006, Introduction to landscape influences on stream habitats and biological assemblages: American Fisheries Society Symposium, v. 48, p. $1-23$. 



\section{Appendix 1. Indicator Descriptions}

Appendix 1 includes a complete list of all indicators listed in tables 3-7, their descriptions, the status rating thresholds used to classify their condition, as well as the data sources and data analysis used. Many of the descriptions and rationales listed in this appendix were taken directly from the Lake Erie Biodiversity Conservation Strategy (LEBCS) (appendixes E and F in Pearsall and others, 2012) and references therein. The aim was to keep continuity between the fine-scale analysis of this study and the large-scale analysis of the LEBCS, as well as to encourage integration and consideration of the data and results from this study into Lake Erie Basin management through the Lake Erie Lakewide Action and Management Plan. Status rating thresholds that were not determined were listed as 'to be determined' (TBD). 


\section{Target-Main Channels}

\section{Key Ecological Attribute-Channel Condition}

\section{Artificial Shoreline Hardening Index}

Description.-This indicator reflects the percent of shoreline protected with artificial structures (for example, seawalls and rip rap) to prevent erosion. Shoreline hardening disrupts natural nearshore coastal processes that drive erosion and sediment transport and, therefore, the nature and extent of nearshore zone habitats and community structure of Great Lakes shorelines (Meadows and others, 2005; Morang and others, 2011, 2012). In the St. Clair-Detroit River System (SCDRS), hardened shorelines have destroyed wetlands and wildlife habitat and alter the flow regime of these rivers by preventing high waters from flooding inland and, instead, redirecting energy downstream. Despite knowledge that the impacts of shoreline hardening have been profound, the impacts of shoreline hardening have been understudied in the Great Lakes (Mackey and Liebenthall, 2005) and have received little attention in efforts to protect or restore coastal systems.

Basis for Assessing Indicator.-Status rating thresholds used for shoreline hardening were the same as those used for the LEBCS (Pearsall and others, 2012) and Lake Ontario Biodiversity Conservation Strategy (LOBCS) (Lake Ontario Biodiversity Strategy Working Group, 2009), which were loosely based upon a shoreline hardening State of the Lakes Ecosystem Conference (SOLEC) indicator (Environment Canada and U.S. Environmental Protection Agency, 2009). This approach will provide consistency and comparability among plans.

Approach.-Geographic information system (GIS) analyses were completed in ArcMap to calculate the shoreline hardening index for each assessment unit using the shoreline hardening vector data. These data are available in the Great Lakes geospatial database (https://www.glahf.org/data/). A shoreline was considered to be hardened if lined with retaining walls or if more than 15 percent of the shoreline (per 100 meters [m] of shoreline) was hardened. Only the shorelines along the main channels and Lake St. Clair were included for those targets. The total length of shoreline classified as hardened was then calculated for each assessment unit.

\begin{tabular}{lcccc}
\hline \multirow{2}{*}{ Segment/Target } & \multicolumn{4}{c}{ Status rating thresholds and classification (percent) } \\
\cline { 2 - 5 } & Poor & Fair & Good & Very good \\
\hline Lake St. Clair & $>40$ & $>30-40$ & $20-30$ & $<20$ \\
Main channels & $>40$ & $20-40$ & $20-30$ & $<20$ \\
Islands & $>40$ & $20-40$ & $10-20$ & $<10$ \\
\hline
\end{tabular}

\section{Percent River Flow Through Chenal Ecarte}

Description.-Herdendorf and others (1986) reported that approximately 5 percent of water from the main stem of the St. Clair River enters the Chenal Ecarte distributary. The Chenal Ecarte, and its distributaries, are the source of river flow for much of the eastern portion of the St. Clair Delta, including Walpole and St. Anne Islands, in Ontario, Canada. Adequate flow through the Chenal Ecarte is needed to maintain the current biodiversity and hydrology of the eastern half of the St. Clair Delta.

Basis for Assessing Indicator- - Qualitative status rating thresholds were taken from Harris and others (2009). Quantitative thresholds need to be determined for this indicator to improve future assessments.

\begin{tabular}{lcccc}
\hline \multirow{2}{*}{ Segment } & \multicolumn{4}{c}{ Status rating thresholds and classification } \\
\cline { 2 - 5 } & \multicolumn{1}{c}{ Poor } & Fair & Good & Very good \\
\hline $\begin{array}{l}\text { Lower St. Clair } \\
\text { River }\end{array}$ & $\begin{array}{c}\text { Flow distribution is signifi- } \\
\text { cantly altered, with ex- } \\
\text { tremely negative impacts } \\
\text { on biota. }\end{array}$ & $\begin{array}{c}\text { Flow distribution is notably } \\
\text { altered, with some nega- } \\
\text { tive impacts on biota. }\end{array}$ & $\begin{array}{c}\text { Flow distribution is moder- } \\
\text { ately altered, but has little } \\
\text { negative impacts on biota. }\end{array}$ & $\begin{array}{c}\text { Mimicking historic flow } \\
\text { distribution. }\end{array}$ \\
\hline
\end{tabular}




\section{Key Ecological Attribute-Community Architecture}

\section{Fish Species Richness-Spawning}

Description.-Evidence indicates that spawning activity is increasing in the SCDRS by species, such as lake whitefish (Coregonus clupeaformis), that historically spawned in large numbers in the Detroit River but that have been absent or rare for many decades (Roseman and others, 2007). Other species including lake sturgeon (Acipenser fulvescens), walleye (Sander vitreus), and white sucker (Catostomus commersonii) are known to spawn in the SCDRS (Thomas and Haas, 2002; Manny and others, 2010; Prichard and others, 2017; Fischer and others, 2018). As such, tracking the richness of spawning species can be an effective indicator of the recovery of these connecting channels.

Basis for Assessing Indicator.-Qualitative status rating thresholds were taken from the LEBCS (Pearsall and others, 2012). Further investigation is necessary to define quantitative measures for this indicator.

\begin{tabular}{ccccc}
\hline \multirow{2}{*}{ Segment } & \multicolumn{4}{c}{ Status rating thresholds and classification } \\
\cline { 2 - 5 } & \multicolumn{2}{c}{ Poor } & Fair & Good \\
\hline Main channels & $\begin{array}{c}\text { Lack of native species } \\
\text { diversity }\end{array}$ & $\begin{array}{c}\text { Moderate diversity of native } \\
\text { species }\end{array}$ & $\begin{array}{c}\text { Dominated by a variety of } \\
\text { native species }\end{array}$ & $\begin{array}{c}\text { Diverse array of fish to sup- } \\
\text { port healthy, productive } \\
\text { fish communities. }\end{array}$ \\
\hline
\end{tabular}

\section{Fish Species Richness—Larval}

Description.-Evidence indicates that spawning activity is increasing by native species that historically spawned in large numbers in the Detroit River but have been absent or rare for many decades (Roseman and others, 2007; Tucker and others, 2018). As such, tracking the richness of larval species can be an effective indicator of the recovery of the St. Clair and Detroit Rivers.

Basis for Assessing Indicator- - Qualitative status rating thresholds were taken from the LEBCS (Pearsall and others, 2012) and further investigation is necessary to define quantitative measures for this indicator.

Approach.-Larval fish have been sampled throughout the SCDRS by U.S. Geological Survey (USGS) Great Lakes Science Center since 2006. The fish species richness accounted for all larval samples taken in the SCDRS in 2013. Because of the difficulty in species identification during the larval stage, the fish species richness is in terms of taxon richness, which in some instances is a species (for example, lake whitefish) and in other instances is only at the family level (for example, Cyprinidae). This would cause the data to underestimate the actual number of species in the segments. Data were from Tucker and others (2018).

\begin{tabular}{|c|c|c|c|c|}
\hline \multirow{2}{*}{ Segment } & \multicolumn{4}{|c|}{ Status rating thresholds and classification } \\
\hline & Poor & Fair & Good & Very good \\
\hline Main channels & $\begin{array}{l}\text { Lack of native species } \\
\text { diversity }\end{array}$ & $\begin{array}{l}\text { Moderate diversity of native } \\
\text { species }\end{array}$ & $\begin{array}{l}\text { Dominated by a variety of } \\
\text { native species }\end{array}$ & $\begin{array}{l}\text { Diverse array of fish to sup- } \\
\text { port healthy, productive } \\
\text { fish communities. }\end{array}$ \\
\hline
\end{tabular}

\section{Wetland Area}

Description.-This indicator represents the total area of wetlands in each assessment unit. Wetlands provide multiple critical ecosystem functions and habitat for numerous plant and wildlife species, and the total area of wetlands is a valuable and direct indicator of coastal wetland viability for a particular area. Wetlands across the Great Lakes have been destroyed by human activities such as shoreline alteration, dredging, construction of jetties and marinas, and others (Manny, 2007), but few references cite the amount of coastal wetland loss relative to historical conditions.

Basis for Assessing Indicator-Data were solicited from the Great Lakes Coastal Wetlands Consortium (available at https://www.glc.org/library/2008-great-lakes-coastal-wetland-monitoring-plan) to calculate the current total wetland area in each assessment unit. In some segments, such as in the Detroit River (Manny, 2007), published assessments enabled quantitative status rating thresholds to be established. However, for most of the assessment units, quantitative status rating thresholds need to be determined for the individual assessment units. The status rating thresholds were taken from the LEBCS (Pearsall and others, 2012). 
Approach.-ArcGIS was used to calculate the total area of coastal wetlands throughout the connecting channels using the Lake Erie Basin Coastal Wetland shapefile (Great Lakes Coastal Wetlands Consortium, 2004). The file was added to by including wetlands around Belle Isle and Peche Island according to Manny (2007). The total area of coastal wetlands was then calculated for each assessment unit.

\begin{tabular}{lllll}
\hline \multirow{2}{*}{ Segment } & \multicolumn{1}{c}{ Status rating thresholds and classification } \\
\cline { 2 - 5 } & \multicolumn{1}{c}{ Poor } & Fair & Good & Very good \\
\hline Detroit River & $\leq 4,215$ acres & $>4,215$ and $<8,430$ acres & $\geq 8,430$ and $<16,860$ acres & $\geq 16,860$ acres \\
St. Clair River & $\begin{array}{l}\text { Greater loss from current } \\
\text { area }\end{array}$ & $\begin{array}{c}\text { Some loss from current } \\
\text { area }\end{array}$ & Current area & Historic area \\
& & & & \\
\hline
\end{tabular}

\section{Key Ecological Attribute-Fish Tissue}

\section{Contaminants Mercury (Walleye)}

Description.- This indicator has been tracked in the Great Lakes for more than 35 years by Federal, Tribal, and State agencies, primarily in recognition of the human health implications of eating fish with high concentrations of mercury (Monson and others, 2011).

Basis for Assessing Indicator.-The safe level target mercury concentration established for human health reasons is 0.52 micrograms per gram wet weight ( $\mu \mathrm{g} / \mathrm{g}$ WW), (allowing for consumption of walleye by nonsensitive groups), although mercury levels in walleye are rising in the Great Lakes Region (Monson and others, 2011). Status rating thresholds were based on the Michigan Department of Community Health standards for fish mercury concentrations (http://www.michigan.gov/ documents/mdch/MDCH_MFCAP_Guidance_Document_417043_7.pdf)_— "fair" recommends 1 meal/month, "good" recommends 2 meals/month, "very good" recommends 4 meals/month or more.

\begin{tabular}{ccccc}
\hline \multirow{2}{*}{ Segment } & \multicolumn{4}{c}{ Status rating thresholds and classification $(\boldsymbol{\mu g} / \mathbf{g ~ W W})$} \\
\cline { 2 - 5 } & Poor & Fair & Good & Very good \\
\hline Main channels & $>1.1$ & $0.53-1.1$ & $0.27-0.52$ & $<0.27$ \\
\hline
\end{tabular}

\section{Contaminants Polychlorinated Biphenyls (Walleye)}

Description.-As with the contaminants mercury (walleye) indicator, this indicator has been established primarily for human health concerns. The polychlorinated biphenyls (PCBs) indicator can serve well as an indicator of water quality, along with measures of other contaminants.

Basis for Assessing Indicator-As described in De Vault and others (1996) and Carlson and Swackhamer (2006), PCBs in fish have been declining since the 1970s but are still above the target of $0.1 \mu \mathrm{g} / \mathrm{g}$ WW established by the Great Lakes Water Quality Agreement (GLWQA). Because most status ratings thresholds are listed as TBD, further investigation is necessary to define quantitative measures for this indicator.

\begin{tabular}{ccccc}
\hline \multirow{2}{*}{ Segment } & \multicolumn{4}{c}{ Status rating thresholds and classification $(\boldsymbol{\mu g} / \mathbf{g} \mathbf{W W})$} \\
\cline { 2 - 5 } & Poor & Fair & Good & Very good \\
\hline Main channels & TBD & 0.1 & TBD & TBD \\
\hline
\end{tabular}

\section{Key Ecological Attribute-Population Structure}

\section{Mean 5-Year Annual Peak Density of Lake Whitefish Larvae}

Description.-This indicator reflects the recently discovered presence of spawning lake whitefish and ongoing survey efforts in the SCDRS (Roseman and others, 2007). The presence of spawning lake whitefish is an indicator of improving water quality since the adoption of the GLWQA in 1972 and can serve as a positive and motivational symbol of system recovery. 
Basis for Assessing Indicator- - Status rating thresholds and current status values for this indicator are based on ongoing surveys (Roseman and others, 2012; Tucker and others, 2018) and expert opinion, and this indicator may only apply well to the Detroit River. Evaluation of this indicator with respect to the St. Clair River is still needed.

Approach.-Larval fish have been sampled throughout the SCDRS by the USGS Great Lakes Science Center since 2006. The maximum peak density (number per 1,000 cubic meters $\left[\mathrm{m}^{3}\right]$ ) was averaged across sites within a segment. Data were from Tucker and others (2018).

\begin{tabular}{lcccc}
\hline \multirow{2}{*}{ Segment } & \multicolumn{4}{c}{ Status rating thresholds and classification $\left(\mathbf{p e r} \mathbf{1 , 0 0 0} \mathbf{~ m}^{\mathbf{3}}\right)$} \\
\cline { 2 - 5 } & Poor & Fair & Good & Very good \\
\hline Detroit River & $<10$ & $10-25$ & $>25-100$ & $>100$ \\
St. Clair River & TBD & TBD & TBD & TBD \\
\hline
\end{tabular}

\section{Key Ecological Attribute-Water Quality}

\section{Mean 3-year Density of Hexagenia}

Description.-Hexagenia, a dominant benthic organism in the nearshore zone of lakes, are important indicators of nearshore health in more productive areas of the Great Lakes that are dominated by soft substrates (Edsall and others, 2005). In addition, Hexagenia can be a very important food source for many benthic feeding fishes, including lake sturgeon (Choudhury and others, 1996; Beamish and others, 1998), yellow perch (Perca flavescens) (Price, 1963; Clady and Hutchinson, 1976), and walleye (Ritchie and Colby, 1988).

Basis for Assessing Indicator.-Status rating thresholds for Hexagenia density (number of individuals per square meter $\left[\mathrm{m}^{2}\right]$ ) in the Lake St. Clair and main channels targets were from the LEBCS (Pearsall and others, 2012), based on Edsall and others (2005) and Environment Canada and U.S. Environmental Protection Agency (2009).

\begin{tabular}{ccccc}
\hline \multirow{2}{*}{ Segment } & \multicolumn{4}{c}{ Status rating thresholds and classification $\left(\mathbf{p e r} \mathbf{~ m}^{\mathbf{2}}\right)$} \\
\cline { 2 - 5 } & Poor & Fair & Good & Very good \\
\hline Lake St. Clair & $<30$ & $30-100$ or $>400$ & $101-200$ or $301-400$ & $201-300$ \\
Main channels & $<2$ & $2-19$ & $20-200$ & $>200$ \\
\hline
\end{tabular}

\section{Mean Growing Season (March-October) Water Level}

Description.-This indicator reflects the importance of water levels during the growing season for the availability of fish spawning habitat and for the vegetation composition of coastal wetlands in the SCDRS.

Basis for Assessing Indicator.-Status rating thresholds for this indicator were based on the International Upper Great Lakes Study analysis of restoration options for increasing Lake Michigan-Huron water levels (International Upper Great Lakes Study, 2011) and were used in Pearsall and others (2012).

Approach.-Water level data were obtained from the National Oceanic and Atmospheric Administration (NOAA), Great Lakes Environmental Research Laboratory (available at https:/www.glerl.noaa.gov/data/wlevels/\#observations) and then graphed to evaluate water levels in the past 5 years. The 5 years that were used to calculate the mean water levels from March through October were 2009-13. The NOAA stations used are as follows: Dunn Paper (upper St. Clair River), St. Clair State Police (middle St. Clair River), Algonac (lower St. Clair River), St. Clair Shores (west Lake St. Clair), Fort Wayne (upper Detroit River), and Gibraltar (lower Detroit River).

\begin{tabular}{ccccc}
\hline \multirow{2}{*}{ Segment } & \multicolumn{4}{c}{ Status rating thresholds and classification } \\
\cline { 2 - 4 } & \multicolumn{2}{c}{ Poor } & Fair & Good \\
\hline Main channels & $\leq 174.1$ or $>176.5 \mathrm{~m}$ for 5 con- & $\leq 174.1$ or $>176.5 \mathrm{~m}$ for any & $>174.1$ and $\leq 176.5 \mathrm{~m}$ for any \\
& secutive years & 3 years in 5 -year window & Not applicable \\
& & & years in a 5 -year window \\
\hline
\end{tabular}




\section{Total Dissolved Solids}

Description.-This indicator reflects the combined amount of all inorganic and organic substances contained in a liquid in suspended form. The total dissolved solids (TDS) indicator is commonly used as an indicator of water quality and was included in the LEBCS (Pearsall and others, 2012).

Basis for Assessing Indicator. - Little information was available to base status rating thresholds for TDS. The New York State surface-water standards for TDS state that TDS "shall not exceed 200 milligrams per liter (mg/L) and shall be kept as low as practicable to maintain the best usage of waters but in no case shall it exceed $500 \mathrm{mg} / \mathrm{L}$ " (URS Corporation and Gomez and Sullivan Engineers, P.C., 2005).

Approach.-The Michigan Department of Environmental Quality (MDEQ), as part of their standard monitoring of the Great Lakes connecting channels, monitors the St. Clair and Detroit Rivers. Data reported were provided by W. Keiper, MDEQ (written commun., 2014). Monthly samples were collected at two locations in each river from April to October 2012. The 2012 mean and median TDS values are reported in table 3. Sample collection and processing methods can be found in Michigan Department of Environmental Quality (2013) and the references therein. These results indicate that TDS could be considered "good", though further refinement of this indicator is needed.

\begin{tabular}{ccccc}
\hline \multirow{2}{*}{ Segment } & \multicolumn{4}{c}{ Status rating thresholds and classification (mg/L) } \\
\cline { 2 - 5 } & Poor & Fair & Good & Very good \\
\hline Main channels & $>500$ & $200-500$ & $<200$ & TBD \\
\hline
\end{tabular}

\section{Total Phosphorus Concentrations}

Description.-Total phosphorus is an important measure of trophic state and maintaining phosphorus concentrations below target levels is important to maintain or achieve desired trophic conditions (mesotrophic) and avoid nuisance and harmful algal blooms (United States and Canada, 2012). Total phosphorus has been measured for decades in the Great Lakes and has been a predominant indicator of eutrophication. Phosphorus reduction targets for the Lake Erie Basin are being revised per the 2012 GLWQA.

Basis for Assessing Indicator-Annex 4 of the GLWQA of 2012 (United States and Canada, 2012) includes total phosphorus concentrations and load targets for Lake Erie (less than or equal to 15 micrograms per liter [ $\mu \mathrm{g} / \mathrm{L}]$ spring mean concentration), which were applied to Lake St. Clair and the main channels because of the lack of established standards for the rivers. Status rating thresholds were not developed for this indicator, except a status rating of very good; therefore, status rating thresholds need to be determined for Lake St. Clair and the main channels.

Approach.-The MDEQ monitors the St. Clair and Detroit Rivers as part of the standard monitoring of the Great Lakes connecting channels. Data reported were provided by W. Keiper, MDEQ (written commun., 2014). Monthly samples were collected at two locations in each river from April to October 2012. The 2012 spring (April/May/June) mean and year median are reported in table 3. Sample collection and processing methods can be found in Michigan Department of Environmental Quality (2013) and the references therein. These results indicate that total phosphorus concentrations could be considered very good, though further refinement of this indicator is needed.

\begin{tabular}{lcccc}
\hline \multirow{2}{*}{ Segment } & \multicolumn{4}{c}{ Status rating thresholds and classification ( $\boldsymbol{\mu g} / \mathbf{L})$} \\
\cline { 2 - 5 } & Poor & Fair & Good & Very good \\
\hline Main channels & TBD & TBD & TBD & $\leq 15$ \\
Lake St. Clair & $>50$ & $<50$ & TBD & $\leq 15$ \\
\hline
\end{tabular}

\section{Percent of Beaches Open During Summer E. coli Monitoring}

Description.-Beach closures because of E. coli concentrations exceeding safe swimming levels have been a concern for much of the SCDRS in the past. The authors of this report chose to monitor the closing of beaches (the result of contamination) because of high $E$. coli concentrations rather than to monitor $E$. coli concentrations specifically. This information on the closing of beaches is simpler to maintain, update, and understand than E. coli concentrations and is a direct measure of its influence to humans' activities.

Basis for Assessing Indicator--Further investigation is necessary to define quantitative status rating thresholds for this indicator. 
Approach.-The percent of days that beaches were open during the swimming season (Environment Canada and U.S. Environmental Protection Agency, 2014) was used to rate the E. coli metric across the connecting channels. Only beaches that were monitored during 2013 were used, except for Belle Isle Beach, which was sampled during 2012 and not 2013. Data were downloaded from the MDEQ website at: http://www.deq.state.mi.us/beach/Default.aspx. Beaches used in this metric in each assessment unit included Belle Isle beach for the upper Detroit River; Pier Park beach, Lake St. Clair Metropark beach, New Baltimore Park beach, and St. Clair Shores Memorial Park beach for west Lake St. Clair; and Chrysler Park beach, Marine City beach, and Marine City diving area for the middle St. Clair River. Beaches that were closed because of reasons other than bacteria were not included in this calculation.

\begin{tabular}{ccccc}
\hline \multirow{2}{*}{ Segment } & \multicolumn{4}{c}{ Status rating thresholds and classification } \\
\cline { 2 - 5 } & Poor & Fair & Good & Very good \\
\hline Main channels & TBD & TBD & TBD & TBD \\
Lake St. Clair & TBD & TBD & TBD & TBD \\
\hline
\end{tabular}

\section{Key Ecological Attribute-Population Size and Dynamics}

\section{Mean Native Mussel Richness Per Site}

Description.-Freshwater mussels are of significant interest in North America given the high diversity of this taxa in North America and the high level imperilment of this group (Master, 1990), as well as the ecological functions freshwater mussels provide (Vaughn and others, 2008). Among these ecological functions is the ability of freshwater mussels to filter large volumes of water, which helps to temper algal populations in productive areas and helps to reduce turbidity. Historically, much more abundant and rich in diversity, the native mussels in the Detroit River and Lake St. Clair have declined substantially through the decades, most likely due to the Dreissenid mussel invasions (zebra mussel [Dreissena polymorpha] and quagga mussel [D. bugensis]; Gillis and Mackie, 1994; Nalepa and others, 1996; Schloesser and others, 1996). However, studies have indicated coastal areas can provide native mussels refuge from Dreissenids (McGoldrick and others, 2009; Crail and others, 2011; Bryan and others, 2013). This indicator describes of the number of species (spp.) collected at each site through freshwater mussel (Unionidae) surveys in the nearshore habitats of the SCDRS.

Basis for Assessing Indicator- -Status rating thresholds are from the LEBCS (Pearsall and others, 2012), based on recent surveys led by D.T. Zanatta (Central Michigan University) and on expert opinion.

Approach.-Mean native mussel richness values were drawn from McGoldrick and others (2009) for Lake St. Clair, but values are still needed for the main channels.

\begin{tabular}{lcccc}
\hline \multirow{2}{*}{ Segment } & \multicolumn{4}{c}{ Status rating thresholds and classification (spp.) } \\
\cline { 2 - 5 } & Poor & Fair & Good & Very good \\
\hline Main channels & $0-2$ & $3-10$ & $>10-15$ & $>15$ \\
Lake St. Clair & $0-2$ & $3-10$ & $>10-15$ & $>15$ \\
\hline
\end{tabular}

\section{Mean Dreissena Density}

Description.-The two Dreissena species that have invaded the Great Lakes, zebra and quagga mussels, have caused significant changes in the Great Lakes ecosystem. In the nearshore zone (less than $15 \mathrm{~m}$ ), these changes have included changes in nearshore nutrient dynamics (Hecky and others, 2004), large outbreaks of nuisance Cladophora (Auer and others, 2010), degradation of spawning reefs (Marsden and Chotkowski, 2001), and eradication of native freshwater mussels from many Great Lakes habitats (Schloesser and others, 1996).

Basis for Assessing Indicator-— Quantitative status rating thresholds need to be determined for Dreissena densities in Lake St. Clair and the main channels.

Approach.-Dreissenid densities were drawn from McGoldrick and others (2009) for Lake St. Clair, but densities are still needed for the main channels. 


\begin{tabular}{lcccc}
\hline \multirow{2}{*}{ Segment } & \multicolumn{4}{c}{ Status rating thresholds and classification } \\
\cline { 2 - 5 } & Poor & Fair & Good & Very good \\
\hline Main channels & Abundant & TBD & TBD & Absent \\
Lake St. Clair & Abundant & TBD & TBD & Absent \\
\hline
\end{tabular}

\section{Native Mussel Abundance}

Description.-Freshwater mussels are of significant interest in North America given the high diversity of this taxa in North America and the high level imperilment of this group (Master, 1990), as well as the ecological functions freshwater mussels provide (Vaughn and others, 2008). Among these ecological functions is the ability of freshwater mussels to filter large volumes of water, which helps to temper algal populations in productive areas and helps to reduce turbidity. Historically, much more abundant and rich in diversity, the native mussels in the Detroit River and Lake St. Clair have declined substantially through the decades, most likely due to the Dreissenid mussel invasion (Gillis and Mackie, 1994; Nalepa and others, 1996; Schloesser and others, 1996). However, studies have indicated coastal areas can provide native mussels refuge from Dreissenids (McGoldrick and others, 2009; Crail and others, 2011; Bryan and others, 2013).

Basis for Assessing Indicator- Quantitative status rating thresholds need to be determined for native mussel abundance in the SCDRS.

Approach.-Richness values were drawn from McGoldrick and others (2009) for lower St. Clair River, but values are still needed for the other main channels segments.

\begin{tabular}{ccccc}
\hline \multirow{2}{*}{ Segment } & \multicolumn{4}{c}{ Status rating thresholds and classification } \\
\cline { 2 - 5 } & Poor & Fair & Good & Very good \\
\hline Main channels & TBD & TBD & TBD & TBD \\
\hline
\end{tabular}

\section{Number Mature Lake Sturgeon}

Description.-Lake sturgeon have been steadily increasing across the Great Lakes, with only a few populations considered large (Hayes and Caroffino, 2012), and lake sturgeon numbers provide a useful and recognizable sign of water-quality and habitat improvements.

Basis for Assessing Indicator-Based on the adult lake sturgeon research in the SCDRS (for example, Thomas and Haas, 2002; Boase and others, 2011) and expert input, status rating thresholds were developed for this indicator in the LEBCS (Pearsall and others, 2012) and were used in this study.

Approach.-Total adult population estimates have been done from mark-recapture studies within the SCDRS. Estimates were provided by J. Chiotti (U.S. Fish and Wildlife Service [USFWS]) using data from Michigan Department of Natural Resources (MDNR), USFWS, and Ontario Ministry of Natural Resources and Forestry (OMNRF) (Chiotti and others, 2013).

\begin{tabular}{|c|c|c|c|c|}
\hline \multirow{2}{*}{ Segment } & \multicolumn{4}{|c|}{ Status rating thresholds and classification } \\
\hline & Poor & Fair & Good & Very good \\
\hline Main channels & No breeding individuals & $\begin{array}{l}>50 \text { breeding individuals } \\
\text { or at least } 5 \text { percent of } \\
\text { population }\end{array}$ & $\begin{array}{l}>100 \text { breeding individuals } \\
\text { or at least } 10 \text { percent of } \\
\text { population }\end{array}$ & $\begin{array}{l}>500 \text { breeding individuals } \\
\text { or at least } 15 \text { percent of } \\
\text { population }\end{array}$ \\
\hline
\end{tabular}




\section{Target—Lake St. Clair}

\section{Key Ecological Attribute-Community Architecture}

\section{3-Year Running Average Total Native Intolerant Fish Species Richness in Annual Bottom Trawl Surveys}

Description.-The survival or presence of many intolerant fish species depends on response to differing levels of eutrophication, which results in stressful conditions such as low oxygen and turbidity. Tracking the richness of intolerant species can provide an indication of ecosystem condition with regards to stress on the fish community from low oxygen or high turbidity conditions. A running average of the richness of intolerant species would recognize variability from interannual fluctuations. Native intolerant species include emerald shiners (Notropis atherinoides), lake sturgeon, rock bass (Ambloplites rupestris), sand shiners (Notropis stramineus), shorthead redhorse (Moxostoma macrolepidotum), silver redhorse (Moxostoma anisurum), smallmouth bass (Micropterus dolomieu), spottail shiner (Notropis hudsonius), and trout-perch (Percopsis omiscomaycus). Intolerant species were taken from Ludsin and others (2001) and references therein.

Basis for Assessing Indicator--The following status rating thresholds were suggested for the western basin of Lake Erie based on a review of Ludsin and others (2001) and should be applicable to Lake St. Clair.

Approach.-The regularly collected trawl data from MDNR can be analyzed for species richness, and trends can be analyzed to assess levels of eutrophication. The fall bottom-trawl data from Thomas and Wills (2013) were used to calculate the 3-year running average of native intolerant fish species richness in western Lake St. Clair until the year 2012.

\begin{tabular}{ccccc}
\hline \multirow{2}{*}{ Segment } & \multicolumn{4}{c}{ Status rating thresholds and classification (spp.) } \\
\cline { 2 - 5 } & Poor & Fair & Good & Very good \\
\hline Lake St. Clair & $<2$ & $2-3$ & $>3-4$ & $>4$ \\
\hline
\end{tabular}

\section{Mean Dreissena Density}

Description.-The two Dreissena species that have invaded the Great Lakes, zebra and quagga mussels, have caused significant changes in the Great Lakes ecosystem. In the nearshore zone (less than $15 \mathrm{~m}$ ), these changes have included changes in nearshore nutrient dynamics (Hecky and others, 2004), large outbreaks of nuisance Cladophora (Auer and others, 2010), degradation of spawning reefs (Marsden and Chotkowski, 2001), and eradication of native freshwater mussels from many Great Lakes habitats (Schloesser and others, 1996).

Basis for Assessing Indicator- - Quantitative status rating thresholds need to be determined for Dreissena densities in Lake St. Clair and the main channels.

Approach.-Dreissenid densities were drawn from McGoldrick and others (2009) for Lake St. Clair, but densities are still needed for the main channels.

\begin{tabular}{lcccc}
\hline \multirow{2}{*}{ Segment } & \multicolumn{4}{c}{ Status rating thresholds and classification } \\
\cline { 2 - 5 } & Poor & Fair & Good & Very good \\
\hline Main channels & Abundant & TBD & TBD & Absent \\
Lake St. Clair & Abundant & TBD & TBD & Absent \\
\hline
\end{tabular}

\section{Smallmouth Bass Population/Relative Abundance}

Description.-Smallmouth bass are a native species with high recreational value in Lake St. Clair. Lake St. Clair has a premier smallmouth bass fishery that accounted for 39 percent of trophy entries into the MDNR Master Angler Program in 2012 (Thomas and Wills, 2013). Population estimates are not available for smallmouth bass in the corridor; however, standard annual fisheries assessments, led by MDNR and OMNRF, could be used to track the relative abundance of adult fish species.

Basis for Assessing Indicator- - Quantitative status rating thresholds need to be determined for smallmouth bass relative abundance in Lake St. Clair, possibly separate status rating thresholds for each Lake St. Clair basin based on the respective surveys led by MDNR and OMNRF. 
Approach.-Data were used from the 2012 MDNR spring trap net survey (Thomas and Wills, 2013) to characterize the status of smallmouth bass in western Lake St. Clair, and 2012 data were used from the Ontario Ministry of Natural Resources (2014) trap net survey to characterize the status of smallmouth bass in eastern Lake St. Clair. Data from 2012 were used to maintain comparability between the west and east portions of Lake St. Clair.

\begin{tabular}{ccccc}
\hline \multirow{2}{*}{ Segment } & \multicolumn{4}{c}{ Status rating thresholds and classification } \\
\cline { 2 - 5 } & Poor & Fair & Good & Very good \\
\hline Lake St. Clair & TBD & TBD & TBD & TBD \\
\hline
\end{tabular}

\section{Walleye Population/Relative Abundance}

Description.-Walleye are very important ecologically and economically in Lake St. Clair (MacLennan and others, 2003), with 28 percent of open water anglers identifying walleye as the target species (Thomas and Towns, 2011). As a top predator in the lake, walleye are important in maintaining the fish community structure of Lake St. Clair. Walleye from Lake St. Clair are also exploited by commercial fisheries in southern Lake Huron (MacLennan and others, 2003). Walleye caught and tagged in Lake St. Clair are known to have wide-ranging movements (Thomas and Hass, 2012), indicating some of the walleye in Lake St. Clair may be part of a larger metapopulation of walleye in the region. Population estimates are not available for walleye in the corridor; however, standard annual fisheries assessments, led by MDNR and OMNRF, could be used to track the relative abundance of adult fish species.

Basis for Assessing Indicator-Quantitative status rating thresholds need to be determined for walleye relative abundance in Lake St. Clair, possibly separate status rating thresholds for each Lake St. Clair basin based on the respective surveys led by MDNR and OMNRF.

Approach.-Data were used from the 2012 MDNR spring trap net survey (Thomas and Wills, 2013) to characterize the status of walleye in western Lake St. Clair, and 2012 data were used from the Ontario Ministry of Natural Resources (2014) trap net survey to characterize the status of walleye in eastern Lake St. Clair. Data from 2012 were used to maintain comparability between the west and east portions of Lake St. Clair.

\begin{tabular}{ccccc}
\hline \multirow{2}{*}{ Segment } & \multicolumn{4}{c}{ Status rating thresholds and classification } \\
\cline { 2 - 5 } & Poor & Fair & Good & Very good \\
\hline Lake St. Clair & TBD & TBD & TBD & TBD \\
\hline
\end{tabular}

\section{Yellow Perch Population/Relative Abundance}

Description.-Yellow perch are very important ecologically and economically in Lake St. Clair, accounting for most of the fish harvested from Lake St. Clair (Thomas and Towns, 2011). Population estimates are not available for yellow perch in the corridor; however, standard annual fisheries assessments, led by MDNR and OMNRF, could be used to track the relative abundance of adult fish species.

Basis for Assessing Indicator- - Quantitative status rating thresholds need to be determined for yellow perch relative abundance in Lake St. Clair, with possible separate status rating thresholds established for each Lake St. Clair basin based on the respective surveys led by MDNR and OMNRF.

Approach.-Data were used from the 2012 MDNR spring trap net survey (Thomas and Wills, 2013) to characterize the status of yellow perch in western Lake St. Clair, and 2012 data were used from the Ontario Ministry of Natural Resources (2014) trap net survey to characterize the status of yellow perch in eastern Lake St. Clair. Data from 2012 were used to maintain comparability between the west and east portions of Lake St. Clair.

\begin{tabular}{ccccc}
\hline \multirow{2}{*}{ Segment } & \multicolumn{4}{c}{ Status rating thresholds and classification } \\
\cline { 2 - 5 } & Poor & Fair & Good & Very good \\
\hline Lake St. Clair & TBD & TBD & TBD & TBD \\
\hline
\end{tabular}




\section{Muskellunge Population/Relative Abundance}

Description.-Lake St. Clair is home to one of the last self-sustaining muskellunge (Esox masquinongy) populations in the Great Lakes with the management objective of providing a trophy muskellunge fishery (MacLennan and others, 2003). In 2012, 60 percent of the entries into the MDNR Master Angler Program were from Lake St. Clair (Thomas and Wills, 2013). Population estimates are not available for muskellunge in the corridor; however, standard annual fisheries assessments, led by MDNR and OMNRF, could be used to track the relative abundance of adult fish species.

Basis for Assessing Indicator-Quantitative status rating thresholds need to be determined for muskellunge relative abundance in Lake St. Clair, with possible separate status rating thresholds established for each Lake St. Clair basin based on the respective surveys led by MDNR and OMNRF.

Approach.-Data were used from the 2012 MDNR spring trap net survey (Thomas and Wills, 2013) to characterize the status of muskellunge in western Lake St. Clair, and 2012 data were used from the Ontario Ministry of Natural Resources (2014) trap net survey to characterize the status of muskellunge in eastern Lake St. Clair. Data from 2012 were used to maintain comparability between the west and east portions of Lake St. Clair.

\begin{tabular}{ccccc}
\hline \multirow{2}{*}{ Segment } & \multicolumn{4}{c}{ Status rating thresholds and classification } \\
\cline { 2 - 5 } & Poor & Fair & Good & Very good \\
\hline Lake St. Clair & TBD & TBD & TBD & TBD \\
\hline
\end{tabular}

\section{Key Ecological Attribute—Soil/Sediment Stability and Movement}

\section{Bed Load Traps and Groins}

Description.-This indicator measures the number of artificial shoreline structures per 100 kilometers $(\mathrm{km})$ of shoreline (structures $/ 100 \mathrm{~km}$ ). Shoreline structures, such as jetties that project out into the lake, disrupt littoral flow patterns and sediment processes and can trap sediment on the updrift side of structures resulting in sediment starved conditions on the downdrift side (Meadows and others, 2005). A substantial amount of data indicates that bed load traps and groins alter shoreline processes, particularly water flow and sediment transport (Herdendorf, 1973, 1987; Carter and others, 1981; Li and others, 2001; Meadows and others, 2005). Shoreline structure density calculations in Goforth and Carman (2005) did not discriminate between large and small structures or docks, so further evaluation of the indicator status rating thresholds and structure density details are needed in the future.

Basis for Assessing Indicator--The status rating thresholds used for this viability analysis were from the LEBCS, based on expert opinion (Pearsall and others, 2012). Published studies generally have been insufficient for identifying thresholds of impacts from perpendicular structures in the lake.

Approach.-Google Earth was used to follow the shoreline of the mainland and islands, and all structures that protruded into the rivers or lake were counted. Sediment trapping on one side of structure was often used as the indicator of a bed load trap and that structure was counted. Structures that exhibited no evidence of sediment trapping were not counted; however, consideration of small docks may be warranted and would require updated status rating thresholds.

\begin{tabular}{lcccc}
\hline \multirow{2}{*}{ Segment/Target } & \multicolumn{3}{c}{ Status rating thresholds and classification (structures/100 km) } \\
\cline { 2 - 5 } & Poor & Fair & Good & Very good \\
\hline Lake St. Clair & $>100$ & $>50-100$ & $>25-50$ & $0-25$ \\
Main channels & $>100$ & $>50-100$ & $>25-50$ & $0-25$ \\
Islands & $>100$ & $>50-100$ & $>25-50$ & $0-25$ \\
\hline
\end{tabular}

\section{Erosion and Deposition Rates (From Tributaries)}

Description.-This indicator reflects the rates of soil erosion and deposition (tons per acre per year [t/ac/yr]) of Lake St. Clair tributaries. Erosion from tributaries contributes sediment loads in the system, and sediment discharge from tributaries has been linked to higher levels of phosphorus in Lake Erie. The Thames River is prone to discharging large sediment plumes into eastern Lake St. Clair. 
Basis for Assessing Indicator.-Status rating thresholds for this indicator were taken from the LEBCS (Pearsall and others, 2012) and the LOBCS (Lake Ontario Biodiversity Strategy Working Group, 2009). These thresholds were based upon several studies evaluating watershed impacts to the nearshore zone ecosystem (Ouyang and others, 2005; Baird and Associates, 2005).

\begin{tabular}{ccccc}
\hline \multirow{2}{*}{ Segment } & \multicolumn{4}{c}{ Status rating thresholds and classification (t/ac/yr) } \\
\cline { 2 - 5 } & Poor & Fair & Good & Very good \\
\hline Lake St. Clair & $>0.125$ & $0.075-0.125$ & $0.025-0.075$ & $<0.025$ \\
\hline
\end{tabular}

\section{Key Ecological Attribute-Coastal and Watershed Contribution}

\section{Artificial Shoreline Hardening Index}

Description.-This indicator reflects the percent of shoreline protected with artificial structures (for example, seawalls and rip rap) to prevent erosion. Shoreline hardening disrupts natural nearshore coastal processes that drive erosion and sediment transport and, therefore, the nature and extent of nearshore zone habitats and community structure of Great Lakes shorelines (Meadows and others, 2005; Morang and others, 2011, 2012). In the SCDRS, hardened shorelines have destroyed wetlands and wildlife habitat and alter the flow regime of these rivers by preventing high waters from flooding inland, and instead, redirecting energy downstream. Despite knowledge that the impacts of shoreline hardening have been profound, the impacts of shoreline hardening have been understudied in the Great Lakes (Mackey and Liebenthall, 2005) and have received little attention in efforts to protect or restore coastal systems.

Basis for Assessing Indicator. - Status rating thresholds used for shoreline hardening were the same as those used for the LEBCS (Pearsall and others, 2012) and Lake Ontario Biodiversity Conservation Strategy (LOBCS) (Lake Ontario Biodiversity Strategy Working Group, 2009), which were loosely based upon a shoreline hardening State of the Lakes Ecosystem Conference (SOLEC) indicator (Environment Canada and U.S. Environmental Protection Agency, 2009). This approach will provide consistency and comparability among plans.

Approach. - GIS analyses were completed in ArcMap to calculate the shoreline hardening index for each assessment unit using the shoreline hardening vector data. These data are available in the Great Lakes geospatial database (https://www.glahf.org/data/). A shoreline was considered to be hardened if lined with retaining walls or if more than 15 percent of the shoreline (per $100 \mathrm{~m}$ of shoreline) was hardened. Only the shorelines along the main channels and Lake St. Clair were included for those targets. The total length of shoreline classified as hardened was then calculated for each assessment unit.

\begin{tabular}{lcccc}
\hline \multirow{2}{*}{ Target } & \multicolumn{4}{c}{ Status rating thresholds and classification (percent) } \\
\cline { 2 - 5 } & Poor & Fair & Good & Very good \\
\hline Lake St. Clair & $>40$ & $>30-40$ & $20-30$ & $<20$ \\
Main channels & $>40$ & $>30-40$ & $20-30$ & $<20$ \\
Islands & $>40$ & $20-40$ & $10-20$ & $<10$ \\
\hline
\end{tabular}

\section{Percent Natural Land Cover in Watershed}

Description.-This indicator quantifies the amount of natural land cover within the watersheds of Lake St. Clair and is important for coastal wetlands as well. Data indicate that the percent of development within the contributing watershed of Great Lakes nearshore zone is important in determining water-quality and biological integrity (Lougheed and others, 2001; Uzarski and others, 2005; Niemi and others, 2009).

Basis for Assessing Indicator--Most published studies generally have been insufficient for identifying thresholds for impacts of changing natural land cover. Status rating thresholds for this indicator followed Pearsall and others (2012) and were based on data presented in Lougheed and others (2001) and Niemi and others (2009).

Approach.-GIS analyses were completed in ArcMap to calculate natural land cover for the contributing areas of each assessment unit. A NOAA Coastal Change Analysis Program (C-CAP) regional land cover (2010) raster of Michigan with 30-m resolution was used for the U.S. portion. Represented natural land cover types included forests, wetlands, grasslands, and shrublands. The new raster was converted to a polygon shapefile to merge with the Ontario vegetation polygon. The Ontario vegetation polygon included dominant vegetation classes (excluding cropland) and was produced by Natural Resources Canada (https:/www.nrcan.gc.ca/earth-sciences/geography/topographic-information). The merged Ontario and U.S. based shapefiles 
were intersected with a shapefile outlining the watersheds of the SCDRS to calculate the percent natural land cover for each assessment unit.

\begin{tabular}{ccccc}
\hline \multirow{2}{*}{ Segment } & \multicolumn{4}{c}{ Status rating thresholds and classification (percent) } \\
\cline { 2 - 5 } & Poor & Fair & Good & Very good \\
\hline Lake St. Clair & $<20$ & $20-45$ & $>45-80$ & $>80$ \\
\hline
\end{tabular}

\section{Percent Natural Land Cover within 2 Kilometers of Lake/Shoreline}

Description.-The literature indicates that alteration of natural land cover within a given area has an impact on natural community condition, ecological processes, and plant and animal population viability (Newmark, 1995; Forman, 1997). By measuring the percent natural land cover of the coastal terrestrial systems, the coastal habitat fragmentation is being measured directly, and the condition of coastal natural communities and the integrity of coastal natural processes are indirectly being measured. The effect of conversion of natural land cover within the coastal terrestrial system of the Great Lakes has similar impacts on Lake St. Clair and coastal wetlands as land use conversion across the watershed, including degraded water quality and impaired biotic communities (Uzarski and others, 2005; Webb, 2008). Conversion of natural land cover also affects aerial migrants (Ewert and Hamas, 1995).

Basis for Assessing Indicator--The same indicator rankings were used in this assessment that were used in the LEBCS (Pearsall and others, 2012) and LOBCS (Lake Ontario Biodiversity Strategy Working Group, 2009). Ideally, these ratings would be based on developed relationships between percent natural land cover and biotic community metrics (for example, index of biotic integrity [IBI]); however, further research to develop such relationships is needed.

Approach.-GIS analyses were completed in ArcMap to calculate natural land cover for the contributing areas of each assessment unit. A NOAA C-CAP regional land cover (2010) raster of Michigan with 30-m resolution was used for the U.S. portion. The raster was extracted using a 2-km buffer around the main channels and Lake St. Clair. Unlike the calculation of natural land cover within watersheds, the 2-km buffer was not limited to being within watersheds. The authors of this report agreed that movement of terrestrial or avian organisms would not be limited by watersheds. Represented natural land cover types included forests, wetlands, grasslands, and shrublands. The new raster was converted to a polygon shapefile to merge with the Ontario vegetation polygon. The Ontario vegetation polygon included dominant vegetation classes (excluding cropland) and was produced by Natural Resources Canada (https://www.nrcan.gc.ca/earth-sciences/geography/topographic-information). The merged Ontario and U.S. based shapefiles were intersected with a shapefile outlining the 2-km buffer of the SCDRS to calculate the percent natural land cover for each assessment unit.

\begin{tabular}{ccccc}
\hline \multirow{2}{*}{ Segment } & \multicolumn{4}{c}{ Status rating thresholds and classification (percent) } \\
\cline { 2 - 5 } & Poor & Fair & Good & Very good \\
\hline Lake St. Clair & $<20$ & $20-45$ & $>45-80$ & $>80$ \\
\hline
\end{tabular}

\section{Key Ecological Attribute—Landscape Pattern (Mosaic) and Structure}

\section{Emergent and Submergent Vegetation Distribution in Protected Embayments and Soft Sediment Areas}

Description.-To support phytophilic fish, submerged aquatic macrophytes are needed in the system. This vegetation is affected by pollutants (Hartig and others, 2007) and exotic species (Knapton and Petrie, 1999). The MDNR mapped species composition and abundance of macrophytes in Lake St. Clair from 2003 to 2007 (Thomas and Haas, 2012). Macrophytes are important to fish in the nearshore lake margin, and the Great Lakes Fishery Commission (2012) includes a goal of "Restore submerged aquatic macrophyte communities in estuaries, embayments, and protected nearshore areas."

Basis for Assessing Indicator-—uantitative status rating thresholds need to be determined for emergent and submergent vegetation distribution in Lake St. Clair. The qualitative status rating thresholds from the LEBCS are listed as a starting framework (Pearsall and others, 2012).

Approach.- The goal of Thomas and Haas (2012) was to approximate the percent cover and diversity of submergent vegetation in Lake St. Clair; therefore, emergent vegetation was not included in this assessment. Approximately 23 submergent plant species were identified in Lake St. Clair from 2003 to 2007. The number of species at a site varied from 1 to 9 species, with 
higher diversity closer to shore. The most dominant species were muskgrass (Chara spp.), wild celery (Vallisneria americana), Richardson's pondweed (Potamogeton richardsonii), and common naiad (Najas flexilis). Percent cover of submergent vegetation was generally greater than 50 percent throughout the lake and large portions had at least 90 percent coverage.

\begin{tabular}{ccccc}
\hline \multirow{2}{*}{ Segment } & \multicolumn{4}{c}{ Status rating thresholds and classification } \\
\cline { 2 - 5 } & Poor & Fair & Good & Very good \\
\hline Lake St. Clair & $\begin{array}{c}\text { Absence or near absence of } \\
\text { vegetation cover/critical } \\
\text { habitat for small fish }\end{array}$ & $\begin{array}{c}\text { Moderate level of vegeta- } \\
\text { tion cover (emergent and } \\
\end{array}$ & $\begin{array}{c}\text { Submergent) } \\
\text { sufficient levels of veg- } \\
\text { etative cover for critical } \\
\text { faunal species habitat }\end{array}$ & $\begin{array}{c}\text { Diverse plant assemblages, } \\
\text { submergent aquatic veg- } \\
\text { etation dominant. }\end{array}$ \\
\hline
\end{tabular}

\section{Key Ecological Attribute-Water Quality}

\section{Dissolved Phosphorus Loads}

Description.-To reduce or prevent harmful algal blooms and nuisance algae, measurement and reduction of phosphorus loads to Lake Erie, Lake St. Clair, and their associated tributaries may be necessary. Phosphorus reduction targets for the Lake Erie Basin are being revised per the 2012 GLWQA. The specific metric to assess dissolved phosphorus loads has not been determined.

Basis for Assessing Indicator-—uantitative status rating thresholds need to be determined for dissolved phosphorus loads in Lake St. Clair.

\begin{tabular}{ccccc}
\hline \multirow{2}{*}{ Segment } & \multicolumn{4}{c}{ Status rating thresholds and classification } \\
\cline { 2 - 5 } & Poor & Fair & Good & Very good \\
\hline Lake St. Clair & TBD & TBD & TBD & TBD \\
\hline
\end{tabular}

\section{Nitrogen}

Description.-Whereas phosphorus is the key limiting nutrient and the focus of management efforts, nitrogen can occasionally limit productivity and should be the focus of ongoing research (Lake Erie Lakewide Action and Management Plan, 2011). As stated in the Binational Nutrient Management Strategy (Lake Erie Lakewide Action and Management Plan, 2011): “...it is important to continue to research and monitor the effects of nitrogen and other nutrients so that management decisions and actions can be adapted to appropriate concerns." The specific metric to assess nitrogen has not been determined.

Basis for Assessing Indicator-—Quantitative status rating thresholds need to be determined for nitrogen in Lake St. Clair.

\begin{tabular}{ccccc}
\hline \multirow{2}{*}{ Segment } & \multicolumn{4}{c}{ Status rating thresholds and classification } \\
\cline { 2 - 5 } & Poor & Fair & Good & Very good \\
\hline Lake St. Clair & TBD & TBD & TBD & TBD \\
\hline
\end{tabular}

\section{Total Phosphorus Concentrations}

Description. - Total phosphorus is an important measure of trophic state and maintaining phosphorus concentrations below target levels is important to maintain or achieve desired trophic conditions (mesotrophic) and avoid nuisance and harmful algal blooms (United States and Canada, 2012). Total phosphorus has been measured for decades in the Great Lakes and has been a predominant indicator of eutrophication. Phosphorus reduction targets for the Lake Erie Basin are being revised per the 2012 GLWQA.

Basis for Assessing Indicator-Annex 4 of the GLWQA of 2012 (United States and Canada, 2012) includes interim total phosphorus concentrations and load targets for Lake Erie $(\leq 15 \mu \mathrm{g} / \mathrm{L}$ spring mean concentration), which were applied to Lake St. Clair. Quantitative status rating thresholds were not developed for this indicator, except very good and poor status ratings and, therefore, need to be determined for total phosphorus concentrations in Lake St. Clair and the main channels. Ratings for poor and fair were based on the thresholds used for the Lake St. Clair water-quality assessments led by Macomb County, Mich. (http://health.macombgov.org/Health-EH-LSCAReport-LSCA2009Report). 
Approach.-In the western Lake St. Clair segment, regular water sampling for 13 offshore stations is led by Macomb County, Mich. The mean total phosphorus values reported for 2009 by sampling location were averaged for this assessment.

\begin{tabular}{rcccc}
\hline \multirow{2}{*}{ Segment } & \multicolumn{4}{c}{ Status rating thresholds and classification $(\boldsymbol{\mu g} / \mathbf{L})$} \\
\cline { 2 - 5 } & Poor & Fair & Good & Very good \\
\hline Main channels & TBD & TBD & TBD & $\leq 15$ \\
Lake St. Clair & $>50$ & $<50$ & TBD & $\leq 15$ \\
\hline
\end{tabular}

\section{Cladophora Standing Crop During Late Summer (August-September)}

Description.-Cladophora is a nuisance algae that grows on rocks and other structures at the bottom of lakes and other water bodies. The substantial physical and chemical changes in habitat conditions caused by Cladophora can substantially alter native species populations (Ward and Ricciardi, 2010).

Basis for Assessing Indicator.-Status rating thresholds for Cladophora density (grams dry weight per square meter $\left[\mathrm{gDW} / \mathrm{m}^{2}\right]$ ) were taken from the LEBCS, based on relationships determined, in part, by Auer and others (2010) (Pearsall and others, 2012).

\begin{tabular}{ccccc}
\hline \multirow{2}{*}{ Segment } & \multicolumn{4}{c}{ Status rating thresholds and classification $\left(\mathbf{g D W} / \mathbf{m}^{2}\right)$} \\
\cline { 2 - 5 } & Poor & Fair & Good & Very good \\
\hline Lake St. Clair & $>80$ & $>30-80$ & $15-30$ & $<15$ \\
\hline
\end{tabular}

\section{Contaminants Mercury (Walleye)}

Description.-This indicator has been tracked in the Great Lakes for more than 35 years by Federal, Tribal, and State agencies, primarily in recognition of the human health implications of eating fish with high concentrations of mercury (Monson and others, 2011).

Basis for Assessing Indicator.-The safe level target mercury concentration established for human health reasons is $0.52 \mu \mathrm{g} / \mathrm{g} \mathrm{WW}$, (allowing for consumption of walleye by nonsensitive groups), although mercury levels in walleye are rising in the Great Lakes Region (Monson and others, 2011). Status rating thresholds were based on the Michigan Department of Community Health standards for fish mercury concentrations (http://www.michigan.gov/documents/mdch/MDCH_MFCAP Guidance_Document_417043_7.pdf)_ " "fair" recommends 1 meal/month, "good" recommends 2 meals/month, "very good" recommends 4 meals/month or more.

\begin{tabular}{lcccc}
\hline \multirow{2}{*}{ Target } & \multicolumn{4}{c}{ Status rating thresholds and classification $(\boldsymbol{\mu g} \mathbf{g} \mathbf{g ~ W W})$} \\
\cline { 2 - 5 } & Poor & Fair & Good & Very good \\
\hline Main channels & $>1.1$ & $0.53-1.1$ & $0.27-0.52$ & $<0.27$ \\
Lake St. Clair & $>1.1$ & $0.53-1.1$ & $0.27-0.52$ & $<0.27$ \\
\hline
\end{tabular}

\section{Contaminants Polychlorinated Biphenyls (Walleye)}

Description.-As with the contaminants mercury (walleye) indicator, this indicator has been established primarily for human health concerns. The PCBs indicator can serve well as an indicator of water quality, along with measures of other contaminants.

Basis for Assessing Indicator-As described in De Vault and others (1996) and Carlson and Swackhamer (2006), PCBs in fish have been declining since the 1970s but are still above the target of $0.1 \mu \mathrm{g} / \mathrm{g} \mathrm{WW}$ established by the GLWQA. Most status ratings thresholds are listed as TBD, therefore, further investigation is necessary to define quantitative measures for this indicator. 


\begin{tabular}{lcccc}
\hline \multirow{2}{*}{ Target } & \multicolumn{4}{c}{ Status rating thresholds and classification $(\boldsymbol{\mu g} / \mathbf{g ~ W W})$} \\
\cline { 2 - 5 } & Poor & Fair & Good & Very good \\
\hline Main channels & TBD & 0.1 & TBD & TBD \\
Lake St. Clair & TBD & 0.1 & TBD & TBD \\
\hline
\end{tabular}

\section{Extent of Harmful Algal Blooms (for example, Microcystis, Lyngbya)}

Description.-This indicator would measure how far algal blooms (with specific attention to harmful algal blooms) extend across Lake St. Clair. Recently (especially since 2011), Lake Erie has incurred blooms extending through much of its western basin. This indicator would determine the aerial extent of algal blooms, such as measured by NOAA satellite tracking, in Lake St. Clair.

Basis for Assessing Indicator- - The following qualitative status rating thresholds were determined in consultation with Maryanne Evans, USGS (oral commun., 2014).

\begin{tabular}{|c|c|c|c|c|}
\hline \multirow{2}{*}{ Segment } & \multicolumn{4}{|c|}{ Status rating thresholds and classification } \\
\hline & Poor & Fair & Good & Very good \\
\hline Lake St. Clair & $\begin{array}{l}\text { Average maximum annual extent } \\
>50 \text { percent of surface area, } \\
\text { species confirmed by field } \\
\text { collections }\end{array}$ & $\begin{array}{l}\text { Open lake blooms visible in } \\
\text { satellite imagery, species con- } \\
\text { firmed by field collections }\end{array}$ & $\begin{array}{l}\text { Blooms confined to bays and } \\
\text { backwater areas, species con- } \\
\text { firmed by field collections }\end{array}$ & None \\
\hline
\end{tabular}

\section{Percent of Beaches Open During Summer E. coli Monitoring}

Description.-Beach closures because of $E$. coli concentrations exceeding safe swimming levels have been a concern for much of the SCDRS in the past. The authors of this report chose to monitor the closing of beaches (the result of contamination) because of high $E$. coli concentrations rather than to monitor $E$. coli concentrations specifically. This information on the closing of beaches is simpler to maintain, update, and understand than E. coli concentrations and is a direct measure of its influence to humans' activities.

Basis for Assessing Indicator-Further investigation is necessary to define quantitative status rating thresholds for this indicator.

Approach.-The percent of days that beaches were open during the swimming season (Environment Canada and U.S. Environmental Protection Agency, 2014) was used to rate the E. coli metric across the connecting channels. Only beaches that were monitored during 2013 were used, except for Belle Isle Beach, which was sampled during 2012 and not 2013. Data were downloaded from the MDEQ website at: http://www.deq.state.mi.us/beach/Default.aspx. Beaches used in this indictor in each assessment unit included Belle Isle beach for the upper Detroit River; Pier Park beach, Lake St. Clair Metropark beach, New Baltimore Park beach, and St. Clair Shores Memorial Park beach for west Lake St. Clair; and Chrysler Park beach, Marine City beach, and Marine City diving area for the middle St. Clair River. Beaches that were closed because of reasons other than bacteria were not included in this calculation.

\begin{tabular}{lcccc}
\hline \multirow{2}{*}{ Segment } & \multicolumn{4}{c}{ Status rating thresholds and classification } \\
\cline { 2 - 5 } & Poor & Fair & Good & Very good \\
\hline Main channels & TBD & TBD & TBD & TBD \\
Lake St. Clair & TBD & TBD & TBD & TBD \\
\hline
\end{tabular}

\section{Key Ecological Attribute-Population Size and Dynamics}

\section{Mean Native Mussel Richness Per Site}

Description.-Freshwater mussels are of significant interest in North America given the high diversity of this taxa in North America and the high level imperilment of this group (Master, 1990), as well as the ecological functions freshwater mussels provide (Vaughn and others, 2008). Among these ecological functions is the ability of freshwater mussels to filter large volumes 
of water, which helps to temper algal populations in productive areas and helps to reduce turbidity. Historically, much more abundant and rich in diversity, the native mussels in the Detroit River and Lake St. Clair have declined substantially through the decades, most likely due to the Dreissenid mussel invasions (zebra and quagga mussels; Gillis and Mackie, 1994; Nalepa and others, 1996; Schloesser and others, 1996). However, studies have indicated coastal areas can provide native mussels refuge from Dreissenids (McGoldrick and others, 2009; Crail and others, 2011; Bryan and others, 2013). This indicator describes of the number of species collected at each site through freshwater mussel (Unionidae) surveys in the nearshore habitats of the SCDRS.

Basis for Assessing Indicator.-Status rating thresholds are from the LEBCS (Pearsall and others, 2012), based on recent surveys led by D.T. Zanatta (Central Michigan University) and on expert opinion.

Approach.-Mean native mussel richness values were drawn from McGoldrick and others (2009) for Lake St. Clair, but values are still needed for the main channels.

\begin{tabular}{lcccc}
\hline \multirow{2}{*}{ Segment } & \multicolumn{4}{c}{ Status rating thresholds and classification (spp.) } \\
\cline { 2 - 5 } & Poor & Fair & Good & Very good \\
\hline Main channels & $0-2$ & $3-10$ & $>10-15$ & $>15$ \\
Lake St. Clair & $0-2$ & $3-10$ & $>10-15$ & $>15$ \\
\hline
\end{tabular}

\section{Key Ecological Attribute-Food Web Linkages}

\section{Mean 3-year Density of Hexagenia}

Description.-Hexagenia, a dominant benthic organism in the nearshore zone of lakes, are important indicators of nearshore health in more productive areas of the Great Lakes that are dominated by soft substrates (Edsall and others, 2005). In addition, Hexagenia can be a very important food source for many benthic feeding fishes, including lake sturgeon (Choudhury and others, 1996; Beamish and others, 1998), yellow perch (Price, 1963; Clady and Hutchinson, 1976), and walleye (Ritchie and Colby, 1988).

Basis for Assessing Indicator--Status rating thresholds for Hexagenia density (number of individuals per $\mathrm{m}^{2}$ ) in the Lake St. Clair and main channels targets were from the LEBCS (Pearsall and others, 2012), based on Edsall and others (2005) and Environment Canada and U.S. Environmental Protection Agency (2009).

\begin{tabular}{ccccc}
\hline \multirow{2}{*}{ Target } & \multicolumn{4}{c}{ Status rating thresholds and classification (per $\mathbf{m}^{2}$ ) } \\
\cline { 2 - 5 } & Poor & Fair & Good & Very good \\
\hline Lake St. Clair & $<30$ & $30-100$ or $>400$ & $101-200$ or $301-400$ & $201-300$ \\
Main channels & $<2$ & $2-19$ & $20-200$ & $>200$ \\
\hline
\end{tabular}

\section{Mean Densities of Rotifers, Copepods, and Cladocerans in Early Summer}

Description.-Zooplankton are a critical food source to larval fish during the late-spring to early-summer when larval fish are transitioning from endogenous to exogenous feeding, also known as the "critical period" (Hjort, 1914). Without adequate zooplankton abundance (of the appropriate sizes) during this critical period, larval fish recruitment and, therefore, adult recruitment into a fishery, is limited (Cushing, 1990).

Basis for Assessing Indicator-_Status rating thresholds for zooplankton density (number per liter [L]) were taken from the LEBCS (Pearsall and others, 2012).

\begin{tabular}{cllll}
\hline \multirow{2}{*}{ Segment } & \multicolumn{3}{c}{ Status rating thresholds and classification (number/L) } \\
\cline { 2 - 5 } & \multicolumn{1}{c}{ Poor } & \multicolumn{1}{c}{ Fair } & \multicolumn{1}{c}{ Good } & \multicolumn{1}{c}{ Very good } \\
\hline Lake St. Clair & Rotifers $<100$ & Rotifers $100-150$ & Rotifers $>150-300$ & Rotifers $>300$ \\
& Copepods $<50$ & Copepods 50-75 & Copepods $>75-125$ & Copepods $>125$ \\
& Cladocerans $<35$ & Cladocerans 35-50 & Cladocerans $>50-75$ & Cladocerans $>75$ \\
\hline
\end{tabular}




\section{Target-Native Migratory Fishes}

\section{Key Ecological Attribute-Access to Spawning Areas}

\section{Percent of Accessible Headwater Stream Habitat (Stream Order 1)}

Description.-Because many different species of fish migrate into tributaries in the Great Lakes (Trautman, 1981; Goodyear and others, 1982), connectivity to a variety of habitats is necessary to maintain populations of all of these species. Stream size is a major habitat component and is correlated with many important physical and chemical habitat variables. Headwater streams are the smallest streams, many of which may be ephemeral. Some headwater streams are far upstream within the watersheds of major rivers, while others flow directly into the SCDRS. Streams with a stream order of 1 were considered headwater streams (Strahler, 1957).

Basis for Assessing Indicator--Quantitative status rating thresholds were from the LEBCS (Pearsall and others, 2012), based on the proportion of headwater streams currently connected to the SCDRS.

Approach.-GIS analyses were completed to determine the proportion of headwater streams within each assessment unit that are connected to the SCDRS (that is, those units not isolated because of dams). The U.S. moderate resolution stream layer (http://www.horizon-systems.com/NHDPlus/NHDPlusV1_04.php) and stream orders (http://www.horizon-systems.com/ nhdplus/StrahlerList.php) were downloaded from the online National Hydrography Dataset Plus (NHDPlus) database. Dam locations and the Ontario stream layer were from the Great Lakes geospatial database (https://www.glahf.org/data/). Watersheds within each assessment unit were split at the location of each of the first dams in each tributary. Percent of streams accessible were then calculated for each assessment unit.

\begin{tabular}{ccccc}
\hline \multirow{2}{*}{ Target } & \multicolumn{4}{c}{ Status rating thresholds and classification (percent) } \\
\cline { 2 - 5 } & Poor & Fair & Good & Very good \\
\hline Lake St. Clair & $<25$ & $25-50$ & $>50-75$ & $>75$ \\
Main channels & $<25$ & $25-50$ & $>50-75$ & $>75$ \\
\hline
\end{tabular}

\section{Percent of Accessible Creek Habitat (Stream Order 2-3)}

Description.-Because many different species of fish migrate into tributaries in the Great Lakes (Trautman, 1981; Goodyear and others, 1982), connectivity to a variety of habitats is necessary to maintain populations of all of these species. Stream size is a major habitat component and is correlated with many important physical and chemical habitat variables. Some creeks are upstream within the watersheds of major rivers, while others flow directly into the SCDRS. Creeks are classified as rivers with a stream order of 2-3 (Strahler, 1957).

Basis for Assessing Indicator-Q Quantitative status rating thresholds were from the LEBCS (Pearsall and others, 2012), based on the proportion of headwater streams currently connected to the SCDRS.

Approach.-GIS analyses were completed to determine the proportion of headwater streams within each assessment unit that are connected to the SCDRS (that is, those units not isolated because of dams). The U.S. moderate resolution stream layer (http://www.horizon-systems.com/NHDPlus/NHDPlusV1_04.php) and stream orders (http:/www.horizon-systems.com/ nhdplus/StrahlerList.php) were downloaded from the online NHDPlus database. Dam locations and the Ontario stream layer were obtained from the Great Lakes geospatial database (https://www.glahf.org/data/). Watersheds within each assessment unit were split at the location of each of the first dams in each tributary. Percent of streams accessible were then calculated for each assessment unit.

\begin{tabular}{lcccc}
\hline \multirow{2}{*}{ Target } & \multicolumn{4}{c}{ Status rating thresholds and classification (percent) } \\
\cline { 2 - 5 } & Poor & Fair & Good & Very good \\
\hline Lake St. Clair & $<25$ & $25-50$ & $>50-75$ & $>75$ \\
Main channels & $<25$ & $25-50$ & $>50-75$ & $>75$ \\
\hline
\end{tabular}




\section{Percent of Accessible Small River Habitat (Stream Order 4-5)}

Description.-Because many different species of fish migrate into tributaries in the Great Lakes (Trautman, 1981; Goodyear and others, 1982), connectivity to a variety of habitats is necessary to maintain populations of all of these species. Stream size is a major habitat component and is correlated with many important physical and chemical habitat variables. Some small rivers are the upstream sections within the watersheds of major rivers, while others flow directly into the SCDRS. Small rivers are rivers with a stream order of 4-5 (Strahler, 1957).

Basis for Assessing Indicator-Quantitative status rating thresholds were from the LEBCS (Pearsall and others, 2012), based on the proportion of headwater streams currently connected to the SCDRS.

Approach.-GIS analyses were completed to determine the proportion of headwater streams within each assessment unit that are connected to the SCDRS (that is, those units not isolated because of dams). The U.S. moderate resolution stream layer (http://www.horizon-systems.com/NHDPlus/NHDPlusV1_04.php) and stream orders (http://www.horizon-systems.com/nhdplus/StrahlerList.php) were downloaded from the online NHDPlus database. Dam locations and the Ontario stream layer were obtained from the Great Lakes geospatial database (https://www.glahf.org/data/). Watersheds within each assessment unit were split at the location of each of the first dams in each tributary. Percent of streams accessible were then calculated for each assessment unit.

\begin{tabular}{ccccc}
\hline \multirow{2}{*}{ Target } & \multicolumn{4}{c}{ Status rating thresholds and classification (percent) } \\
\cline { 2 - 5 } & Poor & Fair & Good & Very good \\
\hline Lake St. Clair & $<25$ & $25-50$ & $>50-75$ & $>75$ \\
Main channels & $<25$ & $25-50$ & $>50-75$ & $>75$ \\
\hline
\end{tabular}

\section{Percent of Accessible Large River Habitat (Stream Order 6 or greater)}

Description.-Because many different species of fish migrate into tributaries of the Great Lakes (Trautman, 1981, Goodyear and others, 1982), connectivity to a variety of habitats is necessary to maintain populations of all of these species. Stream size is a major habitat component and is correlated with many important physical and chemical habitat variables. Large rivers are rivers with a stream order of 6 or greater (Strahler, 1957), but many assessment units did not have any rivers this large.

Basis for Assessing Indicator- - Quantitative status rating thresholds were from the LEBCS (Pearsall and others, 2012), based on the proportion of headwater streams currently connected to the SCDRS.

Approach.-GIS analyses were completed to determine the proportion of headwater streams within each assessment unit that are connected to the SCDRS (that is, those units not isolated because of dams). The U.S. moderate resolution stream layer (http://www.horizon-systems.com/NHDPlus/NHDPlusV1_04.php) and stream orders (http://www.horizon-systems.com/ nhdplus/StrahlerList.php) were downloaded from the online NHDPlus database. Dam locations and the Ontario stream layer were obtained from the Great Lakes geospatial database (https://www.glahf.org/data/). Watersheds within each assessment unit were split at the location of each of the first dams in each tributary. Percent of streams accessible were then calculated for each assessment unit.

\begin{tabular}{ccccc}
\hline \multirow{2}{*}{ Target } & \multicolumn{4}{c}{ Status rating thresholds and classification (percent) } \\
\cline { 2 - 5 } & Poor & Fair & Good & Very good \\
\hline Lake St. Clair & $<25$ & $25-50$ & $>50-75$ & $>75$ \\
Main channels & $<25$ & $25-50$ & $>50-75$ & $>75$ \\
\hline
\end{tabular}

\section{Percent of Accessible Tributary Wetland Habitat}

Description.-Some Great Lakes migratory fish, such as northern pike (Esox lucius) and muskellunge, use tributary systems to access wetland systems upstream (Trautman, 1981). Understanding the extent of tributary wetland habitat accessible from the SCDRS would help target wetland preservation and restoration efforts.

Basis for Assessing Indicator.-Like stream habitat, inland wetland connectivity status rating thresholds were based on quartiles of the proportion of the total wetland habitat within each assessment unit that are connected to the SCDRS (Pearsall and others, 2012). 


\begin{tabular}{ccccc}
\hline \multirow{2}{*}{ Target } & \multicolumn{4}{c}{ Status rating thresholds and classification (percent) } \\
\cline { 2 - 5 } & Poor & Fair & Good & Very good \\
\hline Lake St. Clair & $<25$ & $25-50$ & $>50-75$ & $>75$ \\
Main channels & $<25$ & $25-50$ & $>50-75$ & $>75$ \\
\hline
\end{tabular}

\section{Area of Main Channels Habitat Suitable for Lithophilic Spawners}

Description.-Because many Great Lakes fish species migrate to the SCDRS (Trautman, 1981; Goodyear and others, 1982), connectivity to a variety of habitats is necessary to maintain populations of all of these species. Lithophilic spawners, in particular, generally broadcast spawn on gravel and cobble substrates and respond negatively to urbanization and habitat alteration (Helms and others, 2005). The construction and maintenance of commercial shipping channels during the 20th century removed most of the historic lithophilic spawning habitat in the St. Clair and Detroit Rivers.

Basis for Assessing Indicator:-Quantitative status rating thresholds need to be determined for area of habitat suitable for lithophilic spawners in the main channels. Data requirements will involve a compilation of channel substrate information. The status metric could be based on percentage of suitable lithophilic spawning habitat or the total available area of lithophilic spawning habitat.

Approach.-Side-scan sonar mapping is being completed throughout the SCDRS to evaluate potential locations for artificial reef construction (Gregory Kennedy, U.S. Geological Survey, Great Lakes Science Center, oral commun., 2013). The sidescan sonar data provides information on the amount of habitat suitable for lithophilic spawners, but thus far has been focused on only a few areas. Additional sampling throughout the SCDRS is required before status rankings can be generated. Also, because of the wide array of substrates used by lithophilic spawners, specific substrate types will need to be agreed upon to quantify area of habitat available.

\begin{tabular}{llllc}
\hline \multirow{2}{*}{ Segment } & \multicolumn{4}{c}{ Status rating thresholds and classification } \\
\cline { 2 - 5 } & Poor & Fair & Good & Very good \\
\hline Detroit River & TBD & TBD & TBD & TBD \\
St. Clair River & TBD & TBD & TBD & TBD \\
\hline
\end{tabular}

\section{Key Ecological Attribute-Population Size and Dynamics}

\section{Lake Sturgeon Status Across Tributaries}

Description.-Lake sturgeon are dependent upon tributaries and connecting channels for spawning habitat (Lane and others, 1996; Zollweg and others, 2003). Historically, lake sturgeon were an important ecological and economic component of the SCDRS and Lake Erie fish communities (Leach and Nepszy, 1976; Ryan and others, 2003; Zollweg and others, 2003; Davies and others, 2005). However, the populations of lake sturgeon were decimated by overfishing, dam construction, and habitat degradation (Ryan and others, 2003; Davies and others, 2005), and lake sturgeon numbers provide a useful and recognizable sign of water-quality and habitat improvements.

Basis for Assessing Indicator.-Status rating thresholds were taken from Pearsall and others (2012), based on information in Zollweg and others (2003). "Large" populations were defined by Zollweg and others (2003) as 1,000 or more in the annual spawning run, which is consistent with the SOLEC lake sturgeon indicator.

Approach.-Total adult populations have been estimated from mark-recapture studies within the SCDRS. Estimates were derived using data from MDNR, USFWS, and OMNRF (Chiotti and others, 2013). Further research is needed to determine the number of spawning adults in each segment or individual tributaries. 


\begin{tabular}{|c|c|c|c|c|}
\hline \multirow{2}{*}{ Segment } & \multicolumn{4}{|c|}{ Status rating thresholds and classification } \\
\hline & Poor & Fair & Good & Very good \\
\hline Lake St. Clair & $\begin{array}{l}<50 \text { percent of historic rivers } \\
\text { with remnant spawning } \\
\text { runs and no river with } \\
\text { large spawning run }\end{array}$ & $\begin{array}{l}>50 \text { percent of historic rivers } \\
\text { with remnant spawning } \\
\text { runs or one river (depend- } \\
\text { ing upon segment) with } \\
\text { large spawning run }\end{array}$ & $\begin{array}{l}>50 \text { percent of historic rivers } \\
\text { with remnant spawn- } \\
\text { ing runs and one river } \\
\text { (depending upon segment) } \\
\text { with large spawning run }\end{array}$ & $\begin{array}{l}>75 \text { percent of historic rivers } \\
\text { with remnant spawning } \\
\text { runs and }>1 \text { river (depend- } \\
\text { ing upon segment) with } \\
\text { large spawning run }\end{array}$ \\
\hline
\end{tabular}

\section{Status of Shorthead Redhorse Across Tributaries}

Description.-Shorthead redhorse are one of several Lake Erie redhorse species that migrate into tributary rivers to spawn, including the Detroit and St. Clair Rivers (Goodyear and others, 1982; Eakins, 2013). Shorthead redhorse are among the most susceptible of the redhorse species to habitat fragmentation (Reid and others, 2008a), and the population of shorthead redhorse increases with decreasing fragmentation (Reid and others, 2008b).

Basis for Assessing Indicator--The status rating thresholds of shorthead redhorse populations were based on the proportional estimated abundance of the current population, relative to historic population (Pearsall and others, 2012). Historic shorthead redhorse population levels in the tributaries of the SCDRS are not known, but catches of spawning-ready shorthead redhorse within the segments indicate that they migrate through the system, presumably towards a tributary or main channel.

Approach.-Until historical or desired population levels are established by managers, tracking trends in catch-per-uniteffort (CPUE) will give an indication of the population trajectory with time. The data used for this assessment were USFWS data collected during spring gillnet fish community assessments. CPUE was averaged among the years sampled within a segment. All segments were not sampled every year. Sampling years considered ranged from 2007 to 2013. Data were provided by J. Chiotti, USFWS (written commun., 2014).

\begin{tabular}{|c|c|c|c|c|}
\hline \multirow{2}{*}{ Segment } & \multicolumn{4}{|c|}{ Status rating thresholds and classification } \\
\hline & Poor & Fair & Good & Very good \\
\hline Lake St. Clair & $\begin{array}{l}\text { Tributary spawning popula- } \\
\text { tion }<25 \text { percent of his- } \\
\text { toric levels (estimated) }\end{array}$ & $\begin{array}{l}\text { Tributary spawning popula- } \\
\text { tion } 25-50 \text { percent of } \\
\text { historic levels (estimated) }\end{array}$ & $\begin{array}{l}\text { Tributary spawning popula- } \\
\text { tion } 50-75 \text { percent of } \\
\text { historic levels (estimated) }\end{array}$ & $\begin{array}{l}\text { Tributary spawning popula- } \\
\text { tion }>75 \text { percent of his- } \\
\text { toric levels (estimated) }\end{array}$ \\
\hline Main channels & $\begin{array}{l}\text { Tributary spawning popula- } \\
\text { tion }<25 \text { percent of his- } \\
\text { toric levels (estimated) }\end{array}$ & $\begin{array}{l}\text { Tributary spawning popula- } \\
\text { tion } 25-50 \text { percent of } \\
\text { historic levels (estimated) }\end{array}$ & $\begin{array}{l}\text { Tributary spawning popula- } \\
\text { tion } 50-75 \text { percent of } \\
\text { historic levels (estimated) }\end{array}$ & $\begin{array}{l}\text { Tributary spawning popula- } \\
\text { tion }>75 \text { percent of his- } \\
\text { toric levels (estimated) }\end{array}$ \\
\hline
\end{tabular}

\section{Status of Walleye Across Tributaries}

Description.-Walleye are very important ecologically and economically in the SCDRS (Thomas and Towns, 2011; Thomas and Wills, 2013) and tributary spawning populations provide a major component of walleye populations across the Great Lakes and within the SCDRS (Lane and others, 1996; Mion and others, 1998; Davies and others, 2005).

Basis for Assessing Indicator.-The status rating thresholds of walleye populations were based on the proportional estimated abundance of the current population, relative to estimated historic populations (Pearsall and others, 2012). Historic population levels in the tributaries of the SCDRS are not known, but catches of spawning-ready walleye within the segments indicate that they migrate through the system, presumably towards a tributary or main channel.

Approach.- Until historical or desired population levels are established by managers, tracking trends in CPUE will give an indication of the population trajectory with time. The data used for this assessment were USFWS data collected during spring gillnet fish community assessments. CPUE was averaged among the years sample within a segment. All segments were not sampled every year. Sampling years considered ranged from 2007 to 2013. Data were provided by J. Chiotti, USFWS (written commun., 2014). 


\begin{tabular}{|c|c|c|c|c|}
\hline \multirow{2}{*}{ Segment } & \multicolumn{4}{|c|}{ Status rating thresholds and classification } \\
\hline & Poor & Fair & Good & Very good \\
\hline Lake St. Clair & $\begin{array}{l}\text { Tributary spawning popula- } \\
\text { tion }<25 \text { percent of his- } \\
\text { toric levels (estimated) }\end{array}$ & $\begin{array}{l}\text { Tributary spawning popula- } \\
\text { tion } 25-50 \text { percent of } \\
\text { historic levels (estimated) }\end{array}$ & $\begin{array}{l}\text { Tributary spawning popula- } \\
\text { tion } 50-75 \text { percent of } \\
\text { historic levels (estimated) }\end{array}$ & $\begin{array}{l}\text { Tributary spawning popula- } \\
\text { tion }>75 \text { percent of his- } \\
\text { toric levels (estimated) }\end{array}$ \\
\hline Main channels & $\begin{array}{l}\text { Tributary spawning popula- } \\
\text { tion }<25 \text { percent of his- } \\
\text { toric levels (estimated) }\end{array}$ & $\begin{array}{l}\text { Tributary spawning popula- } \\
\text { tion } 25-50 \text { percent of } \\
\text { historic levels (estimated) }\end{array}$ & $\begin{array}{l}\text { Tributary spawning popula- } \\
\text { tion } 50-75 \text { percent of } \\
\text { historic levels (estimated) }\end{array}$ & $\begin{array}{l}\text { Tributary spawning popula- } \\
\text { tion }>75 \text { percent of his- } \\
\text { toric levels (estimated) }\end{array}$ \\
\hline
\end{tabular}

\section{Status of White Suckers Across Tributaries}

Description.-Spawning runs of white suckers in the Great Lakes are widespread (Klingler and others, 2003; Burtner, 2009; Childress, 2010) and represent the highest biomass of tributary spawning migratory fish species across the Great Lakes. White suckers, given their abundance and high biomass of spawning runs, likely play particularly important functional roles among the native migratory fishes (Burtner, 2009; Childress, 2010; Flecker and others, 2010).

Basis for Assessing Indicator.-The status rating thresholds of white sucker populations were based on the proportional estimated abundance of the current population, relative to historic population (Pearsall and others, 2012). Historic population levels in the tributaries of the SCDRS are not known, but catches of spawning-ready white sucker within the segments indicate that they migrate through the system, presumably towards a tributary or main channel.

Approach.-Until historical or desired population levels are established by managers, tracking trends in CPUE will give an indication of the population trajectory with time. The data used for this assessment were USFWS data collected during spring gillnet fish community assessments. CPUE was averaged among the years sample within a segment. All segments were not sampled every year. Sampling years considered ranged from 2007 to 2013. Data were provided by J. Chiotti, USFWS (written commun. 2014).

\begin{tabular}{|c|c|c|c|c|}
\hline \multirow{2}{*}{ Segment } & \multicolumn{4}{|c|}{ Status rating thresholds and classification } \\
\hline & Poor & Fair & Good & Very good \\
\hline Lake St. Clair & $\begin{array}{l}\text { Tributary spawning popula- } \\
\text { tion }<25 \text { percent of his- } \\
\text { toric levels (estimated) }\end{array}$ & $\begin{array}{l}\text { Tributary spawning popula- } \\
\text { tion } 25-50 \text { percent of } \\
\text { historic levels (estimated) }\end{array}$ & $\begin{array}{l}\text { Tributary spawning popula- } \\
\text { tion } 50-75 \text { percent of } \\
\text { historic levels (estimated) }\end{array}$ & $\begin{array}{l}\text { Tributary spawning popula- } \\
\text { tion }>75 \text { percent of his- } \\
\text { toric levels (estimated) }\end{array}$ \\
\hline Main channels & $\begin{array}{l}\text { Tributary spawning popula- } \\
\text { tion }<25 \text { percent of his- } \\
\text { toric levels (estimated) }\end{array}$ & $\begin{array}{l}\text { Tributary spawning popula- } \\
\text { tion } 25-50 \text { percent of } \\
\text { historic levels (estimated) }\end{array}$ & $\begin{array}{l}\text { Tributary spawning popula- } \\
\text { tion } 50-75 \text { percent of } \\
\text { historic levels (estimated) }\end{array}$ & $\begin{array}{l}\text { Tributary spawning popula- } \\
\text { tion }>75 \text { percent of his- } \\
\text { toric levels (estimated) }\end{array}$ \\
\hline
\end{tabular}

\section{Target-Islands}

\section{Key Ecological Attribute-Connectivity Among Communities and Ecosystems}

\section{Road Density on Islands}

Description.-The Great Lakes Region is spanned by extensive road networks that have substantial ecological impacts (disrupting wildlife movements and behavior, modifying habitats, altering water drainage patterns, introducing exotic species, and modifying microclimates) on the surrounding lands, including coastal areas. Roads facilitate land development and further the expansion of the road network itself; therefore, roads can be precursors to future impacts (Riitters and Wickham, 2003).

Basis for Assessing Indicator.-The status rating thresholds use the road density (meters per square kilometer $\left[\mathrm{m} / \mathrm{km}^{2}\right]$ ) on the islands and these were the same thresholds used in the LEBCS (Pearsall and others, 2012) and LOBCS (Lake Ontario Biodiversity Strategy Working Group, 2009). These ratings were based on information from Riitters and Wickham (2003) and the Eastern Ontario Model Forest (Bland and others, 2006).

Approach.-Within ArcGIS 10.1, the Detailed Streets base layer was used to calculate the road density (Esri, 2010). Roads included streets; highways; interstate highways; roads with and without limited access; secondary, connecting, local, and rural roads; and roads with special characteristics. The Detailed Streets layer was intersected with the layer containing the islands to 
calculate the total distance of roads on the islands. The total area of the islands was summed by specific assessment unit in order to calculate road density by assessment units.

\begin{tabular}{rcccc}
\hline \multirow{2}{*}{ Segment } & \multicolumn{4}{c}{ Status rating thresholds and classification $\left(\mathbf{m} / \mathbf{k m}^{2}\right)$} \\
\cline { 2 - 5 } & Poor & Fair & Good & Very good \\
\hline Lake St. Clair & $>2,000$ & $1,250-2,000$ & $500-1,250$ & $<500$ \\
Main channels & $>2,000$ & $1,250-2,000$ & $500-1,250$ & $<500$ \\
\hline
\end{tabular}

\section{Key Ecological Attribute—Landscape Pattern (Mosaic) and Structure}

\section{House Density on Island}

Description. - This indicator describes the density of houses (number of buildings per $\mathrm{km}^{2}\left[\right.$ buildings $\left./ \mathrm{km}^{2}\right]$ ) on islands in the SCDRS. Housing density is an estimator of the degree of fragmentation and disturbance.

Basis for Assessing Indicator--Status rating thresholds for housing density were adopted from the LEBCS (Pearsall and others, 2012).

Approach.-For the U.S. coastal area, U.S. Census block data were used; which are made available by Esri and Tele Atlas North America, Inc. For Ontario, the house density was not calculated because the Ontario building structure polygon, as used in calculating house density on islands, did not match well with the actual abundances of houses inland in Ontario. Therefore, only the house density for the U.S. area was calculated and reported for this indicator. Using these data and ArcMap, the housing density on islands was calculated for each assessment unit.

\begin{tabular}{rcccc}
\hline \multirow{2}{*}{ Segment } & \multicolumn{4}{c}{ Status rating thresholds and classification (buildings//km²) } \\
\cline { 2 - 5 } & Poor & Fair & Good & Very good \\
\hline Lake St. Clair & $>40$ & $21-40$ & $11-20$ & $<10$ \\
Main channels & $>40$ & $21-40$ & $11-20$ & $<10$ \\
\hline
\end{tabular}

\section{Key Ecological Attribute-Size/Extent of Characteristic Communities/Ecosystems}

\section{Percent Natural Land Cover on Entire Island}

Description.-This indicator is primarily based on the best estimate of the amount of natural cover needed to maintain natural processes, including the amount of natural cover needed to maintain populations of area-sensitive breeding species.

Basis for Assessing Indicator.-Status rating thresholds for this indicator were taken from the LEBCS (Pearsall and others, 2012) and were based on expert opinion and published research (Robinson and others, 1995).

Approach.-GIS analyses were completed in ArcMap to calculate natural land cover for the contributing areas of each assessment unit. A NOAA C-CAP regional land cover (2010) raster of Michigan with 30-m resolution was used for the U.S. portion. The raster that included islands in the SCDRS was extracted, and forests, wetlands, grasslands, and shrublands were used as natural land cover. The new raster was converted to a polygon shapefile to merge with the Ontario vegetation polygon. The Ontario vegetation polygon included dominant vegetation classes (excluding cropland) and was produced by Natural Resources Canada (https://www.nrcan.gc.ca/earth-sciences/geography/topographic-information). The merged Ontario and U.S. based shapefiles were intersected with a shapefile outlining islands in the SCDRS to calculate the percent natural land cover for each assessment unit.

\begin{tabular}{lcccc}
\hline \multirow{2}{*}{ Segment } & \multicolumn{4}{c}{ Status rating thresholds and classification (percent) } \\
\cline { 2 - 5 } & Poor & Fair & Good & Very good \\
\hline Lake St. Clair & $<20$ & $20-40$ & $>40-70$ & $>70$ \\
Main channels & $<20$ & $20-40$ & $>40-70$ & $>70$ \\
\hline
\end{tabular}




\section{Key Ecological Attribute-Soil/Sediment Stability and Movement}

\section{Artificial Shoreline Hardening Index}

Description.-This indicator reflects the percent of shoreline protected with artificial structures (for example, seawalls and rip rap) to prevent erosion. Shoreline hardening disrupts natural nearshore coastal processes that drive erosion and sediment transport and, therefore, the nature and extent of nearshore zone habitats and community structure of Great Lakes shorelines (Meadows and others, 2005; Morang and others, 2011, 2012). In the SCDRS, hardened shorelines have destroyed wetlands and wildlife habitat and alter the flow regime of these rivers by preventing high waters from flooding inland and, instead, redirecting energy downstream. Despite knowledge that the impacts of shoreline hardening have been profound, the impacts of shoreline hardening have been understudied in the Great Lakes (Mackey and Liebenthall, 2005) and have received little attention in efforts to protect or restore coastal systems.

Basis for Assessing Indicator.-Status rating thresholds used for shoreline hardening were the same as those used for the LEBCS (Pearsall and others, 2012) and Lake Ontario Biodiversity Conservation Strategy (LOBCS) (Lake Ontario Biodiversity Strategy Working Group, 2009), which were loosely based upon a shoreline hardening State of the Lakes Ecosystem Conference (SOLEC) indicator (Environment Canada and U.S. Environmental Protection Agency, 2009). This approach will provide consistency and comparability among plans.

Approach.-GIS analyses were completed in ArcMap to calculate the shoreline hardening index for each assessment unit using the shoreline hardening vector data. These data are available in the Great Lakes geospatial database (https://www.glahf.org/data/). A shoreline was considered to be hardened if lined with retaining walls or if more than 15 percent of the shoreline (per $100 \mathrm{~m}$ of shoreline) was hardened. Only the shorelines along the main channels and Lake St. Clair were included for those targets. The total length of shoreline classified as hardened was then calculated for each assessment unit.

\begin{tabular}{lcccc}
\hline \multirow{2}{*}{ Segment } & \multicolumn{4}{c}{ Status rating thresholds and classification (percent) } \\
\cline { 2 - 5 } & Poor & Fair & Good & Very good \\
\hline Lake St. Clair & $>40$ & $>30-40$ & $20-30$ & $<20$ \\
Main channels & $>40$ & $>30-40$ & $20-30$ & $<20$ \\
Islands & $>40$ & $20-40$ & $10-20$ & $<10$ \\
\hline
\end{tabular}

\section{Bed Load Traps and Groins}

Description.-This indicator measures the number of artificial shoreline structures per $100 \mathrm{~km}$ of shoreline (structures $/ 100 \mathrm{~km}$ ). Shoreline structures, such as jetties that project out into the lake, disrupt littoral flow patterns and sediment processes and can trap sediment on the updrift side of structures resulting in sediment starved conditions on the downdrift side (Meadows and others, 2005). A substantial amount of data indicates that bed load traps and groins alter shoreline processes, particularly water flow and sediment transport (Herdendorf, 1973, 1987; Carter and others, 1981; Li and others, 2001; Meadows and others, 2005). Shoreline structure density calculations in Goforth and Carman (2005) did not discriminate between large and small structures or docks, so further evaluation of the indicator status rating thresholds and structure density details are needed in the future.

Basis for Assessing Indicator--The status rating thresholds used for this viability analysis were from the LEBCS, based on expert opinion (Pearsall and others, 2012). Published studies generally have been insufficient for identifying thresholds of impacts from perpendicular structures in the lake.

Approach.- Google Earth was used to follow the shoreline of the mainland and islands, and all structures that protruded into the rivers or lake were counted. Sediment trapping on one side of structure was often used as the indicator of a bed load trap and that structure was counted. Structures that exhibited no evidence of sediment trapping were not counted; however, consideration of small docks may be warranted and would require updated status rating thresholds.

\begin{tabular}{lcccc}
\hline \multirow{2}{*}{ Segment/Target } & \multicolumn{4}{c}{ Status rating thresholds and classification (structures/100 km) } \\
\cline { 2 - 4 } & Poor & Fair & Good & Very good \\
\hline Lake St. Clair & $>100$ & $>50-100$ & $>25-50$ & $0-25$ \\
Main channels & $>100$ & $>50-100$ & $>25-50$ & $0-25$ \\
Islands & $>100$ & $>50-100$ & $>25-50$ & $0-25$ \\
\hline
\end{tabular}




\section{Key Ecological Attribute-Conservation Status}

\section{Percentage of High-Ranked Islands that are in Conservation Status}

Description.-Islands are very important within the SCDRS and have formal conservation designation, which helps to ensure adequate habitat and function for the ecosystem and its biota, especially the species using the corridor during migration.

Basis for Assessing Indicator. - Status rating thresholds for this indicator are based on expert opinion solicited during the LEBCS development (Pearsall and others, 2012).

Approach.-The percent of islands in conservation status was calculated using ArcGIS 10.1. The area in conservation status was calculated using the Conservation and Recreation Lands GIS layer from Ducks Unlimited Great Lakes/Atlantic Regional Office and was accessed from http://www.ducks.org/conservation/glaro/carl-gis-layer. Only areas considered as conservation in management type were used.

\begin{tabular}{rcccc}
\hline \multirow{2}{*}{ Segment } & \multicolumn{4}{c}{ Status rating thresholds and classification (percent) } \\
\cline { 2 - 5 } & Poor & Fair & Good & Very good \\
\hline Lake St. Clair & $<20$ & $20-40$ & $>40-70$ & $>70$ \\
Main channels & $<20$ & $20-40$ & $>40-70$ & $>70$ \\
\hline
\end{tabular}

\section{Target-Coastal Wetlands}

\section{Key Ecological Attribute-Abundance and Diversity of Amphibians}

\section{Amphibian Community-Based Coastal Wetland Index of Biotic Integrity}

Description.-This indicator captures the status of amphibians, specifically, frogs and toads (anurans) in coastal wetlands. Essentially, this indicator is the same as the SOLEC draft indicator for Wetland Anurans (Timmermans and others, 2008; Archer and others, 2009b) and is part of a Great Lakes Basin-wide monitoring project funded through the U.S. Environmental Protection Agency Great Lakes Restoration Initiative (GLRI).

Basis for Assessing Indicator.-The status rating thresholds were taken from the LEBCS (Pearsall and others, 2012).

Approach.-Data were made available from Bird Studies Canada, which has coordinated surveys across the Great Lakes Region for as many as 15 years through the volunteer based Marsh Monitoring Program (Archer and others, 2009b). The average amphibian IBI values were calculated for marsh routes within $2 \mathrm{~km}$ of the shoreline in each assessment unit. IBIs were calculated by Bird Studies Canada using the Crewe and Timmermans (2005) methodology. Amphibian IBI values varied considerably at the few locations that were sampled annually. Because locations were not sampled consistently from 1999 to 2013, the mean IBI for all available years was used. In addition, the inconsistent sampling led to IBI values to be driven by single sampling events or older data. The upper St. Clair River assessment unit had a single sampling event during 2008, whereas data collected in east Lake St. Clair were prior to 2004. A more thorough and updated amphibian assessment across all assessment units will provide an improved indication of coastal wetland quality across the SCDRS.

\begin{tabular}{rcccc}
\hline \multirow{2}{*}{ Segment } & \multicolumn{4}{c}{ Status rating thresholds and classification (IBI) } \\
\cline { 2 - 5 } & Poor & Fair & Good & Very good \\
\hline Lake St. Clair & $<25$ & $25-50$ & $>50-75$ & $>75$ \\
Main channels & $<25$ & $25-50$ & $>50-75$ & $>75$ \\
\hline
\end{tabular}

\section{Key Ecological Attribute-Abundance and Diversity of Wetland Dependent Bird Species}

\section{Marsh Bird Index of Biotic Integrity}

Description.-This indicator captures the status of birds in coastal wetlands. The marsh bird IBI indicator is the same as the SOLEC draft indicator for Wetland Birds (Grabas and others, 2008; Archer and others, 2009a) and is part of a Great Lakes Basin-wide monitoring project funded through the GLRI. 
Basis for Assessing Indicator-The status rating thresholds were taken from the LEBCS (Pearsall and others, 2012). Approach.-Data were made available from Bird Studies Canada, which has coordinated surveys across the Great Lakes Region for as many as 15 years through the volunteer based Marsh Monitoring Program (2009). Using ArcMap, the average marsh bird IBI values were calculated for marsh routes within $2 \mathrm{~km}$ of the shoreline in each assessment unit. IBI values were calculated by Bird Studies Canada using the Crewe and Timmermans (2005) methodology. Marsh bird IBI values varied considerably at the few locations that were sampled annually. Because locations were not sampled consistently from 1999 to 2013 , the mean IBI values for all available years was used. In addition, the inconsistent sampling led to IBI values to be driven by single sampling events or older data. The west Lake St. Clair assessment unit had a single sampling event during 2011, whereas data collected in lower St. Clair River were prior to 2005. A more thorough and updated marsh bird assessment across all assessment units will provide an improved indication of coastal wetland quality across the SCDRS.

\begin{tabular}{ccccc}
\hline \multirow{2}{*}{ Segment } & \multicolumn{4}{c}{ Status rating thresholds and classification (IBI) } \\
\cline { 2 - 5 } & Poor & Fair & Good & Very good \\
\hline Lake St. Clair & $0-20$ & $20-40$ & $40-60$ & $>60$ \\
Main channels & $0-20$ & $20-40$ & $40-60$ & $>60$ \\
\hline
\end{tabular}

\section{Key Ecological Attribute-Fish Habitat Quality}

\section{Wetland Fish Index of Wetland Quality}

Description.-This indicator is based on the work of Lougheed and Chow-Fraser (2002) who demonstrated that the Wetland Fish Index could effectively detect water-quality improvements because fisheries and environmental variables are incorporated into the index. The Wetland Fish Index is essentially an earlier version of the SOLEC indicator that is being developed for use across the Great Lakes Basin for coastal wetland fish community health (Sass and others, 2009).

Basis for Assessing Indicator.-The status rating thresholds were taken from the LEBCS (Pearsall and others, 2012).

\begin{tabular}{lcccc}
\hline \multirow{2}{*}{ Segment } & \multicolumn{4}{c}{ Status rating thresholds and classification (IBI) } \\
\cline { 2 - 5 } & Poor & Fair & Good & Very good \\
\hline Lake St. Clair & $<2.5$ & $2.5-3.25$ & $>3.25-3.75$ & $>3.75$ \\
Main channels & $<2.5$ & $2.5-3.25$ & $>3.25-3.75$ & $>3.75$ \\
\hline
\end{tabular}

\section{Key Ecological Attribute-Macroinvertebrate Quality}

\section{Invertebrate Index of Biotic Integrity}

Description.-A basin-wide coastal wetland survey project funded by the GLRI collected extensive invertebrate data on all Great Lakes, using methods from Uzarski and others (2004). These data are being used to develop a SOLEC indicator for coastal wetland invertebrate communities. Details on field methods and calculations of the IBI are available in Uzarski and others (2004).

Basis for Assessing Indicator- - Quantitative status rating thresholds for invertebrate IBI need to be developed for the SCDRS.

Approach.-Data were collected, during 2006, as part of the Area of Concern wetland monitoring initiative (Archer and others, 2006). IBI values were calculated by D. Tozer (Bird Studies Canada) using the Uzarski and others (2004) methodology. All samples were collected in the St. Clair River, with most samples from in the lower St. Clair River.

\begin{tabular}{|c|c|c|c|c|}
\hline \multirow{2}{*}{ Segment } & \multicolumn{4}{|c|}{ Status rating thresholds and classification } \\
\hline & Poor & Fair & Good & Very good \\
\hline Lake St. Clair & Extremely degraded & $\begin{array}{l}\text { Degraded or moderately } \\
\text { degraded }\end{array}$ & $\begin{array}{l}\text { Moderately impacted or } \\
\text { mildly impacted }\end{array}$ & Reference condition \\
\hline Main channels & Extremely degraded & $\begin{array}{l}\text { Degraded or moderately } \\
\text { degraded }\end{array}$ & $\begin{array}{l}\text { Moderately impacted or } \\
\text { mildly impacted }\end{array}$ & Reference condition \\
\hline
\end{tabular}




\section{Key Ecological Attribute-Species Composition/Dominance}

\section{Percent Coverage of Phragmites}

Description.-Nonnative, invasive plants occupy space that otherwise would be occupied by native species and can fundamentally change the structure, composition, and processes of a coastal wetland. Common reed (Phragmites australis) is a nonnative species that is particularly harmful because it grows in dense monocultures, spreads quickly and widely, and is eaten by virtually no insects or herbivores.

Basis for Assessing Indicator--Status rating thresholds were taken from the LEBCS (Pearsall and others, 2012).

Approach.-The USGS and Michigan Technological Research Institute (Bourgeau-Chavez and others, 2013) have developed a shapefile of Phragmites infestations greater than 0.2 hectare in size within $10 \mathrm{~km}$ of the U.S. shorelines of the Great Lakes (available at http://cida.usgs.gov/glri/phragmites). Using ArcMap, this shapefile was intersected with the Great Lakes Coastal Wetlands Consortium (2004) shapefile of coastal wetlands to assess the percent coverage of Phragmites in all wetlands, and then the percentage of Phragmites was calculated for each assessment unit. These percentages are only considering the U.S. side of the SCDRS; data from Ontario are needed.

\begin{tabular}{rcccc}
\hline \multirow{2}{*}{ Segment } & \multicolumn{4}{c}{ Status rating thresholds and classification (percent) } \\
\cline { 2 - 5 } & Poor & Fair & Good & Very good \\
\hline Lake St. Clair & $>50$ & $50-20$ & $20-5$ & $<5$ \\
Main channels & $>50$ & $50-20$ & $20-5$ & $<5$ \\
\hline
\end{tabular}

\section{Key Ecological Attribute-Species Composition/Dominance}

\section{Wetland Macrophyte Index}

Description.-Wetland macrophytes are directly influenced by water quality; therefore, impairment in wetland quality can be reflected by taxonomic composition of the aquatic plant community. Croft and Chow-Fraser (2007) developed the wetland macrophyte index from the statistical relations of biotic communities along a gradient of deteriorating water quality and using plant presence/absence data for 127 coastal wetlands from all five Great Lakes.

Basis for Assessing Indicator-Indicator status rating thresholds were taken from the LEBCS wetland fish index (Pearsall and others, 2012). Because no wetland in the Great Lakes had an index score greater than 4, the wetland macrophyte index ratings put forth in Croft and Chow-Fraser (2007) were not used.

Approach.-A wetland macrophyte index was calculated using submergent vegetation data collected concurrently with a seining survey in the SCDRS (E. Roseman, U.S. Geological Survey, Great Lakes Science Center, unpub. data, 2012). Values were used from Croft and Chow-Fraser (2007) to calculate the wetland macrophyte index, but horned pondweed (Zannichella palustris), a submergent species, or any emergent species were not included. Horned pondweed was not included in the index because it was not in Croft and Chow-Fraser (2007) and may have influenced the score for the middle St. Clair River assessment unit. Many of the species in Lake St. Clair were not in Croft and Chow-Fraser (2007) and, therefore, the index for the lake assessment units could not be estimated. Additional research is required to expand the Croft and Chow-Fraser (2007) study to span all macrophyte species and to increase macrophyte sampling in the SCDRS to better represent the wetland quality throughout the connecting channels.

\begin{tabular}{lcccc}
\hline \multirow{2}{*}{ Segment } & \multicolumn{4}{c}{ Status rating thresholds and classification } \\
\cline { 2 - 5 } & Poor & Fair & Good & Very good \\
\hline Lake St. Clair & $<2.5$ & $2.5-3.25$ & $>3.25-3.75$ & $>3.75$ \\
Main channels & $<2.5$ & $2.5-3.25$ & $>3.25-3.75$ & $>3.75$ \\
\hline
\end{tabular}

\section{Key Ecological Attribute-Spawning Habitat Quality and Accessibility}

\section{Spawning/Recruitment Success of Representative Coastal Wetland Spawners}

Description.-This indicator is in need of full development to complement the wetland fish IBI indicator, but be more reflective of the role of coastal wetlands as critical spawning habitat for many Great Lakes fish species. 
Basis for Assessing Indicator- - Quantitative status ranking thresholds need to be developed for this indicator within the SCDRS, but the qualitative thresholds were taken from the LEBCS (Pearsall and others, 2012).

\begin{tabular}{ccccc}
\hline \multirow{2}{*}{ Segment } & \multicolumn{3}{c}{ Status rating thresholds and classification } \\
\cline { 2 - 5 } & Poor & Fair & Good & Very good \\
\hline Lake St. Clair & Very little recruitment & Some recruitment & Good recruitment & Excellent recruitment \\
Main channels & Very little recruitment & Some recruitment & Good recruitment & Excellent recruitment \\
\hline
\end{tabular}

\section{Key Ecological Attribute-Trophic Structure}

\section{Wetland Zooplankton Index}

Description.-This indicator is based on the work of Lougheed and Chow-Fraser (2002), which demonstrated that the wetland zooplankton index could effectively detect water-quality improvements.

Basis for Assessing Indicator--Status rating thresholds for the wetland zooplankton index were taken from the LEBCS (Pearsall and others, 2012).

\begin{tabular}{ccccc}
\hline \multirow{2}{*}{ Segment } & \multicolumn{4}{c}{ Status rating thresholds and classification } \\
\cline { 2 - 5 } & Poor & Fair & Good & Very good \\
\hline Lake St. Clair & $<1.75$ & $1.75-2.75$ & $>2.75-3.75$ & $>3.75$ \\
Main channels & $<1.75$ & $1.75-2.75$ & $>2.75-3.75$ & $>3.75$ \\
\hline
\end{tabular}

\section{Key Ecological Attribute-Connectivity Among Communities and Ecosystems}

\section{Percent Natural Land Cover in Watershed}

Description.-This indicator quantifies the amount of natural land cover within the watersheds of Lake St. Clair and is important for coastal wetlands as well. Data indicate that the percent of development within the contributing watershed of Great Lakes nearshore zone is important in determining water-quality and biological integrity (Lougheed and others, 2001; Uzarski and others, 2005; Niemi and others, 2009).

Basis for Assessing Indicator--Most published studies generally have been insufficient for identifying thresholds for impacts. Status rating thresholds were from Pearsall and others (2012), based on data presented in Lougheed and others (2001) and Niemi and others (2009).

Approach.-GIS analyses were completed in ArcMap to calculate natural land cover for the contributing areas of each assessment unit. A NOAA C-CAP regional land cover (2010) raster of Michigan with 30-m resolution was used for the U.S. portion. The raster was extracted by the watersheds layer. Raster cell values of 1 represented the natural land cover types that included forests, wetlands, grasslands, and shrublands. The Ontario vegetation polygon included dominant vegetation classes (excluding cropland) and was produced by Natural Resources Canada (https://www.nrcan.gc.ca/earth-sciences/geography/ topographic-information).

\begin{tabular}{rcccc}
\hline \multirow{2}{*}{ Segment } & \multicolumn{4}{c}{ Status rating thresholds and classification (percent) } \\
\cline { 2 - 5 } & Poor & Fair & Good & Very good \\
\hline Lake St. Clair & $<40$ & $40-60$ & $>60-80$ & $>80$ \\
Main channels & $<40$ & $40-60$ & $>60-80$ & $>80$ \\
\hline
\end{tabular}




\section{Key Ecological Attribute-Connectivity Among Communities and Ecosystems}

\section{Percent Natural Land Cover within 500 meters of Mapped Wetlands}

Description.-This indicator recognizes the impacts of loss of natural land cover in coastal terrestrial areas on adjacent coastal wetlands. Adjacent land use can extend over large areas, requiring a large amount of natural land cover near wetlands (Houlahan and Findlay, 2003).

Basis for Assessing Indicator-Published studies that quantify the relation between percentage of adjacent natural land cover and condition of coastal wetlands are not available; therefore, status rating thresholds for this indicator are based on the LEBCS (Pearsall and others, 2012).

Approach.-ArcGIS was used to calculate the total area of coastal wetlands throughout the connecting channels using the Lake Erie Basin Coastal Wetland shapefile (Great Lakes Coastal Wetlands Consortium, 2004). The file was added to by including wetlands around Belle Isle and Peche Island according to Manny (2007). A 500-m buffer was generated around the wetlands and was clipped to only have a buffer on land and not water. The clipped buffer was then intersected with the same natural land cover files used in the previous land cover metrics. The percent natural land cover within the $500-\mathrm{m}$ buffer around wetlands was then calculated for each assessment unit.

\begin{tabular}{rcccc}
\hline \multirow{2}{*}{ Segment } & \multicolumn{4}{c}{ Status rating thresholds and classification (percent) } \\
\cline { 2 - 5 } & Poor & Fair & Good & Very good \\
\hline Lake St. Clair & $<20$ & $20-40$ & $>40-70$ & $>70$ \\
Main channels & $<20$ & $20-40$ & $>40-70$ & $>70$ \\
\hline
\end{tabular}

\section{Key Ecological Attribute-Water Level Regime}

\section{Mean Growing Season (March-October) Water Level}

Description.-This indicator reflects the importance of water levels during the growing season for the availability of fish spawning habitat and for the vegetation composition of coastal wetlands in the SCDRS.

Basis for Assessing Indicator--Status rating thresholds for this indicator were based on the International Upper Great Lakes Study analysis of restoration options for increasing Lake Michigan-Huron water levels (International Upper Great Lakes Study, 2011) and were used in Pearsall and others (2012).

Approach.-Water level data (m above sea level) were obtained from the NOAA Great Lakes Environmental Research Laboratory (available at https:/www.glerl.noaa.gov/data/wlevels/\#observations) and then graphed to evaluate water levels in the past 5 years. The 5 years that were used to calculate the mean water levels from March through October were 2009-13. The NOAA stations used to obtain the data include Dunn Paper (upper St. Clair River), St. Clair State Police (middle St. Clair River), Algonac (lower St. Clair River), St. Clair Shores (west Lake St. Clair), Fort Wayne (upper Detroit River), and Gibraltar (lower Detroit River).

\begin{tabular}{|c|c|c|c|c|}
\hline \multirow{2}{*}{ Segment } & \multicolumn{4}{|c|}{ Status rating thresholds and classification } \\
\hline & Poor & Fair & Good & Very good \\
\hline Lake St. Clair & $\begin{array}{l}\leq 174.1 \text { or }>176.5 \mathrm{~m} \text { for } 5 \text { consecu- } \\
\text { tive years }\end{array}$ & $\begin{array}{l}\leq 174.1 \text { or }>176.5 \mathrm{~m} \text { for any } \\
3 \text { years in a } 5 \text {-year window }\end{array}$ & $\begin{array}{r}>174.1 \text { and } \leq 176.5 \mathrm{~m} \text { for any } \\
3 \text { years in a } 5 \text {-year window }\end{array}$ & - \\
\hline Main channels & $\begin{array}{l}\leq 174.1 \text { or }>176.5 \mathrm{~m} \text { for } 5 \text { consecu- } \\
\text { tive years }\end{array}$ & $\begin{array}{l}\leq 174.1 \text { or }>176.5 \mathrm{~m} \text { for any } \\
3 \text { years in a } 5 \text {-year window }\end{array}$ & $\begin{array}{r}>174.1 \text { and } \leq 176.5 \mathrm{~m} \text { for any } \\
3 \text { years in a } 5 \text {-year window }\end{array}$ & - \\
\hline
\end{tabular}

\section{Key Ecological Attribute-Water Quality}

\section{Total Phosphorus Concentration}

Description.-Total phosphorus is an important measure of trophic state and keeping phosphorus below target levels is important to maintain or achieve desired trophic conditions (mesotrophic) and avoid nuisance and harmful algal blooms (United States and Canada, 2012). Total phosphorus has been measured for decades in the Great Lakes and has been a predominant 
measure of phosphorus as an indicator of eutrophication. Phosphorus reduction targets for the Lake Erie Basin are being revised per the 2012 GLWQA.

Basis for Assessing Indicator--Status rating thresholds for mean annual total phosphorus concentration in coastal wetlands were taken from the LEBCS (Pearsall and others, 2012). The Lake Erie Binational Nutrient Management Strategy (Lake Erie Lakewide Action and Management Plan, 2011) recommends a target of one recording of $<30 \mu \mathrm{g} / \mathrm{L}$ per year; however, sufficient data for coastal wetlands are limited.

\begin{tabular}{lcccc}
\hline \multirow{2}{*}{ Segment } & \multicolumn{4}{c}{ Status rating thresholds and classification ( $\mathbf{\mu g} / \mathbf{L})$} \\
\cline { 2 - 5 } & Poor & Fair & Good & Very good \\
\hline Lake St. Clair & TBD & TBD & $<30$ & TBD \\
Main channels & TBD & TBD & $<30$ & TBD \\
\hline
\end{tabular}

\section{Water Quality Index for Wetland Quality}

Description.-The Water Quality Index score provides a snapshot of coastal wetland condition according to the degree of anthropogenic disturbance, which is reflected by enrichment of nutrients and suspended solids in the water column, as well as conductivity and temperature (Chow-Fraser, 2006). More than 200 Great Lakes coastal wetlands have been surveyed between 1998 and 2008 using this method, mostly in lakes Erie and Huron, using six categories of relative degradation.

Basis for Assessing Indicator.-The same status rating thresholds were used in this assessment that were used in the Lake Huron Biodiversity Strategy and LEBCS (Franks Taylor and others, 2010; Pearsall and others, 2012).

Approach.-The Water Quality Index results from Chow-Fraser (2006) indicated that wetlands in the Detroit River were considered very degraded and highly degraded, whereas wetlands in western Lake St. Clair were very good. These values were not used in the results because the values were measured prior to 2004 and more thorough investigations are required in the future.

\begin{tabular}{lcccc}
\hline \multirow{2}{*}{ Segment } & \multicolumn{4}{c}{ Status rating thresholds and classification } \\
\cline { 2 - 5 } & Poor & Fair & Good & Very good \\
\hline Lake St. Clair & -3 to -1 & $>-1$ to 0 & $>0$ to 1 & $>1$ to 3 \\
Main channels & -3 to -1 & $>-1$ to 0 & $>0$ to 1 & $>1$ to 3 \\
\hline
\end{tabular}

\section{Key Ecological Attribute-Size/Extent of Characteristic Communities}

\section{Wetland Area}

Description.-This indicator represents the total area of wetlands in each assessment unit. Wetlands provide multiple critical ecosystem functions and habitat for numerous plant and wildlife species, and the total area of wetlands is a valuable and direct indicator of coastal wetland viability for a particular area. Wetlands across the Great Lakes have been destroyed by human activities such as shoreline alteration, dredging, construction of jetties and marinas, and others (for example, Manny, 2007), but few references cite the amount of coastal wetland loss relative to historical conditions.

Basis for Assessing Indicator-The status rating thresholds were taken from the LEBCS (Pearsall and others, 2012). Most of the assessment units need quantitative thresholds to be determined.

Approach.—Data were solicited from the Great Lakes Coastal Wetlands Consortium (available at https://www.glc.org/ library/2008-great-lakes-coastal-wetland-monitoring-plan) to calculate the current total wetland area in each assessment unit. In some segments, such as the Detroit River, published assessments enabled quantitative rating thresholds to be established. ArcGIS was used to calculate the total area of coastal wetlands throughout the connecting channels using the Lake Erie Basin Coastal Wetland shapefile (Great Lakes Coastal Wetlands Consortium, 2004). The file was added to by including wetlands around Belle Isle and Peche Island according to Manny (2007). The area was then calculated for each assessment unit.

\begin{tabular}{|c|c|c|c|c|}
\hline \multirow{2}{*}{ Segment } & \multicolumn{4}{|c|}{ Status rating thresholds and classification (acres) } \\
\hline & Poor & Fair & Good & Very good \\
\hline Detroit River & $\leq 4,215$ & $>4,215$ and $<8,430$ & $\geq 8,430$ and $<16,860$ & $\geq 16,860$ \\
\hline
\end{tabular}




\section{Target-Coastal Terrestrial Systems}

\section{Key Ecological Attribute-Connectivity Among Communities and Ecosystems}

\section{Road Density Within 2 Kilometers of Shoreline}

Description.-Existing information indicates that the Great Lakes Region is spanned by extensive road networks. Roads have substantial ecological impacts on the surrounding lands, including coastal areas. These roads can be precursors to future impacts, because they facilitate land development and the further expansion of the road network itself (Riitters and Wickham, 2003).

Basis for Assessing Indicator--The same status rating thresholds were used in this assessment that were used in the LEBCS (Pearsall and others, 2012) and LOBCS (Lake Ontario Biodiversity Strategy Working Group, 2009); these thresholds were based on information from Riitters and Wickham (2003) and the Eastern Ontario Model Forest (Bland and others, 2006).

Approach.-Road density $\left(\mathrm{m} / \mathrm{km}^{2}\right)$ within $2 \mathrm{~km}$ of the shoreline was calculated in ArcGIS $10.1 \mathrm{using}$ the Detailed Streets base layer (Esri, 2010). Roads included streets, highways, interstate highways, roads with and without limited access, secondary, connecting, local and rural roads, and roads with special characteristics. The Detailed Streets layer was intersected with the layer containing the $2-\mathrm{km}$ buffer to calculate the total distance of roads by assessment unit within the area of the buffer.

\begin{tabular}{lcccc}
\hline \multirow{2}{*}{ Segment } & \multicolumn{4}{c}{ Status rating thresholds and classification $\left(\mathbf{m} / \mathbf{k m}^{2}\right)$} \\
\cline { 2 - 5 } & Poor & Fair & Good & Very good \\
\hline Lake St. Clair & $>2,000$ & $1,250-2,000$ & $500-1,250$ & $<500$ \\
Main channels & $>2,000$ & $1,250-2,000$ & $500-1,250$ & $<500$ \\
\hline
\end{tabular}

\section{Key Ecological Attribute—Landscape Pattern (Mosaic) and Structure}

\section{House Density Within 500 Meters of Coast}

Description.-This indicator describes the density of houses and buildings within $500 \mathrm{~m}$ of the SCDRS shoreline. Housing density is a reasonable estimator of the degree of fragmentation and disturbance within a coastal assessment unit. The ratings for this indicator need to be further evaluated to provide evidence for the relation between house density and ecosystem viability.

Basis for Assessing Indicator.-The status rating thresholds for this indicator were adopted from the LEBCS; however, the thresholds were considered to be not well developed and experts were not confident of the ratings (Pearsall and others, 2012).

Approach.-For the U.S. coastal area, the U.S. Census block data were used; data are available by Esri and Tele Atlas North America, Inc. For Ontario, the house density was not calculated because the Ontario building structure polygon, as used in calculating house density on islands, did not match well with the actual abundances of houses inland in Ontario. Therefore, only the house density for the U.S. area was calculated for this indicator. Using these data and using ArcMap, the housing density (buildings $/ \mathrm{km}^{2}$ ) were estimated for the 500 -m buffers within each assessment unit.

\begin{tabular}{lcccc}
\hline \multirow{2}{*}{ Segment } & \multicolumn{4}{c}{ Status rating thresholds and classification (buildings/km²) } \\
\cline { 2 - 5 } & Poor & Fair & Good & Very good \\
\hline Lake St. Clair & $>40$ & $21-40$ & $11-20$ & $<10$ \\
Main channels & $>40$ & $21-40$ & $11-20$ & $<10$ \\
\hline
\end{tabular}

\section{Key Ecological Attribute-Extent of Characteristic Communities/Ecosystems}

\section{Percent Natural Land Cover within 2 Kilometers of Lake/Shoreline}

Description.-The literature indicates that alteration of natural land cover within a given area has an impact on natural community condition, ecological processes, and plant and animal population viability (Newmark, 1995; Forman and Collinge, 1997). By measuring the percent natural land cover of the coastal terrestrial systems, the coastal habitat fragmentation is directly being measured, and the condition of coastal natural communities as well as the integrity of coastal natural processes are indirectly being measured. The effect of conversion of natural land cover within the coastal terrestrial system of the Great Lakes has 
similar impacts on Lake St. Clair and coastal wetlands as land use conversion across the watershed, including degraded water quality and impaired biotic communities (Uzarski and others, 2005; Webb, 2008). Conversion of natural land cover within $2 \mathrm{~km}$ of the coastal terrestrial system also affects aerial migrants (Ewert and Hamas, 1995).

Basis for Assessing Indicator.-The same indicator rating thresholds were used in this assessment that were used in the LEBCS (Pearsall and others, 2012) and LOBCS (Lake Ontario Biodiversity Strategy Working Group, 2009).

Approach.-GIS analyses were completed in ArcMap to calculate natural land cover for the contributing areas of each assessment unit. A NOAA C-CAP regional land cover (2010) raster of Michigan with 30-m resolution was used for the U.S. portion. The raster was extracted by a 2-km buffer around the main channels and Lake St. Clair. Unlike the calculation of natural land cover within watersheds, the $2-\mathrm{km}$ buffer was not limited to being within watersheds. The authors of this report agreed that movement of terrestrial or avian organisms would not be limited by watersheds. Represented natural land cover types included forests, wetlands, grasslands, and shrublands. The raster was converted to a polygon shapefile to merge with the Ontario vegetation polygon. The Ontario vegetation polygon included dominant vegetation classes (excluding cropland) and was produced by Natural Resources Canada (https://www.nrcan.gc.ca/earth-sciences/geography/topographic-information). The merged Ontario and U.S. based shapefiles were intersected with a shapefile outlining the 2-km buffer of the SCDRS to calculate the percent natural land cover for each assessment unit.

\begin{tabular}{ccccc}
\hline \multirow{2}{*}{ Segment } & \multicolumn{4}{c}{ Status rating thresholds and classification (percent) } \\
\cline { 2 - 5 } & Poor & Fair & Good & Very good \\
\hline Lake St. Clair & $<20$ & $20-40$ & $>40-70$ & $>70$ \\
Main channels & $<20$ & $20-40$ & $>40-70$ & $>70$ \\
\hline
\end{tabular}

\section{Key Ecological Attribute-Soil/Sediment Stability and Movement}

\section{Artificial Shoreline Hardening Index}

Description.-This indicator reflects the percent of shoreline protected with artificial structures (for example, seawalls and rip rap) to prevent erosion. Shoreline hardening disrupts natural nearshore coastal processes that drive erosion and sediment transport and, therefore, the nature and extent of nearshore zone habitats and community structure of Great Lakes shorelines (Meadows and others, 2005; Morang and others, 2011, 2012). In the SCDRS, hardened shorelines have destroyed wetlands and wildlife habitat and alter the flow regime of these rivers by preventing high waters from flooding inland, and instead, redirecting energy downstream. Despite knowledge that the impacts of shoreline hardening have been profound, the impacts of shoreline hardening have been understudied in the Great Lakes (Mackey and Liebenthall, 2005) and have received little attention in efforts to protect or restore coastal systems.

Basis for Assessing Indicator.-Status rating thresholds used for shoreline hardening were the same as those used for the LEBCS (Pearsall and others, 2012) and Lake Ontario Biodiversity Conservation Strategy (LOBCS) (Lake Ontario Biodiversity Strategy Working Group, 2009), which were loosely based upon a shoreline hardening State of the Lakes Ecosystem Conference (SOLEC) indicator (Environment Canada and U.S. Environmental Protection Agency, 2009). This approach will provide consistency and comparability among plans.

Approach.-GIS analyses were completed in ArcMap to calculate the shoreline hardening index for each assessment unit using the shoreline hardening vector data. These data are available in the Great Lakes geospatial database (https://www.glahf.org/data/). A shoreline was considered to be hardened if lined with retaining walls or if more than 15 percent of the shoreline (per $100 \mathrm{~m}$ of shoreline) was hardened. Only the shorelines along the main channels and Lake St. Clair were included for those targets. The total length of shoreline classified as hardened was then calculated for each assessment unit.

\begin{tabular}{lcccc}
\hline \multirow{2}{*}{ Segment/Target } & \multicolumn{4}{c}{ Status rating thresholds and classification (percent) } \\
\cline { 2 - 5 } & Poor & Fair & Good & Very good \\
\hline Lake St. Clair & $>40$ & $>30-40$ & $20-30$ & $<20$ \\
Main channels & $>40$ & $>30-40$ & $20-30$ & $<20$ \\
Islands & $>40$ & $20-40$ & $10-20$ & $<10$ \\
\hline
\end{tabular}




\section{Bed Load Traps and Groins}

Description.-This indicator measures the number of artificial shoreline structures per $100 \mathrm{~km}$ of shoreline (structures $/ 100 \mathrm{~km}$ ). Shoreline structures, such as jetties that project out into the lake, disrupt littoral flow patterns and sediment processes and can trap sediment on the updrift side of structures resulting in sediment starved conditions on the downdrift side (Meadows and others, 2005). A substantial amount of data indicates that bed load traps and groins alter shoreline processes, particularly water flow and sediment transport (Herdendorf, 1973, 1987; Carter and others, 1981; Li and others, 2001; Meadows and others, 2005). Shoreline structure density calculations in Goforth and Carman (2005) did not discriminate between large and small structures or docks, so further evaluation of the indicator status rating thresholds and structure density details are needed in the future.

Basis for Assessing Indicator--The status rating thresholds used for this viability analysis were from the LEBCS, based on expert opinion (Pearsall and others, 2012). Published studies generally have been insufficient for identifying thresholds of impacts from perpendicular structures in the lake.

Approach. - Google Earth was used to follow the shoreline of the mainland and islands, and all structures that protruded into the rivers or lake were counted. Sediment trapping on one side of structure was often used as the indicator of a bed load trap and that structure was counted. Structures that exhibited no evidence of sediment trapping were not counted; however, consideration of small docks may be warranted and would require updated status rating thresholds.

\begin{tabular}{lcccc}
\hline \multirow{2}{*}{ Segment/Target } & \multicolumn{3}{c}{ Status rating thresholds and classification (structures/100 $\mathbf{~ k m}$ ) } \\
\cline { 2 - 5 } & Poor & Fair & Good & Very good \\
\hline Lake St. Clair & $>100$ & $>50-100$ & $>25-50$ & $0-25$ \\
Main channels & $>100$ & $>50-100$ & $>25-50$ & $0-25$ \\
Islands & $>100$ & $>50-100$ & $>25-50$ & $0-25$ \\
\hline
\end{tabular}

\section{Key Ecological Attribute-Size/Extent of Characteristic Communities/Ecosystems}

\section{Percentage of Area 2-10 Kilometers From Lake that is in Natural Land Cover}

Description.-The literature indicates that alteration of natural land cover in the surrounding landscape has an impact on habitat quality, community structure, species viability, and ecological processes. The quality and type of land cover surrounding particular habitats or natural communities impacts species richness and viability, nest predation, establishment of invasive species, and ecological processes such as seed dispersal, pollination, flooding, and hydrologic fluctuations (Murcia, 1995; Saab, 1999).

Basis for Assessing Indicator-The same status rating thresholds were used for this assessment that were used in the LOBCS (Lake Ontario Biodiversity Strategy Working Group, 2009), LEBCS (Pearsall and others, 2012), and Lake Huron Biodiversity Strategy (Franks Taylor and others, 2010), which were based on information from the following articles and organizations: Findlay and others (2001), Dodd and Smith (2003), Environment Canada and Central Lake Ontario Conservation Authority (2004), and Rubbo and Kiesecker (2005).

Approach.-GIS analyses were completed in ArcMap to calculate natural land cover for the contributing areas of each assessment unit. A NOAA C-CAP regional land cover (2010) raster of Michigan with 30-m resolution was used for the U.S. portion. The raster was extracted by a $2-\mathrm{km}$ buffer around the main channels and Lake St. Clair. Unlike the calculation of natural land cover within watersheds, the buffer of 2-10 km was not limited to being within watersheds. The authors of this report agreed that movement of terrestrial or avian organisms would not be limited by watersheds. Values that represented the natural land cover types included forests, wetlands, grasslands, and shrublands. The raster was converted to a polygon shapefile to merge with the Ontario vegetation polygon. The Ontario vegetation polygon included dominant vegetation classes (excluding cropland) and was produced by Natural Resources Canada (https:/www.nrcan.gc.ca/earth-sciences/geography/topographicinformation). The merged Ontario and U.S. based shapefiles were intersected with a shapefile outlining the SCDRS buffer of $2-10 \mathrm{~km}$ to calculate the percent natural land cover for each assessment unit.

\begin{tabular}{lcccc}
\hline \multirow{2}{*}{ Segment } & \multicolumn{4}{c}{ Status rating thresholds and classification (percent) } \\
\cline { 2 - 5 } & Poor & Fair & Good & Very good \\
\hline Lake St. Clair & $<20$ & $20-40$ & $>40-70$ & $>70$ \\
Main channels & $<20$ & $20-40$ & $>40-70$ & $>70$ \\
\hline
\end{tabular}




\section{Target-Aerial Migrants}

\section{Key Ecological Attribute-Anthropogenic Disturbance}

\section{Mean Distance of Suitable Shorebird Habitat From Disturbance Factor}

Description.-This indicator is based on response of shorebirds to anthropogenic disturbance factors such as hiking, running, walking, and response to dogs accompanied by people.

Basis for Assessing Indicator.-Status rating thresholds were taken from the LEBCS (Pearsall and others, 2012), based on Borgmann (2011) and references therein.

Approach.-Disturbance of shorebirds was calculated in ArcMap using habitat suitability data from the Great Lakes Migratory Bird Stopover Portal (Ewert and others, 2012; accessed at: https://data.pointblue.org/partners/mwadc/index. php?page=stopover-map-tool). The suitability data from the raster were extracted within a 2-km buffer (inland only) along the shoreline to allow comparability across all assessment units. Roads were considered as disturbance that may alter shorebird behavior (Borgmann, 2011). To calculate the average distance to disturbances (roads), we converted the raster to points (approximately 9,000 points) to run a "near" analysis to calculate the distance (in meters) to the nearest road. The road layer was the same as used in the road density indicator. Although other factors such as trails and boat traffic alter shorebird behavior, these factors could not be accounted for in this analysis. Therefore, the results underestimate the disturbance of shorebirds. The use of creel data to generate angling and marina/boat ramp hotspots may allow future analysis to account for boating traffic in addition to roads.

\begin{tabular}{ccccc}
\hline \multirow{2}{*}{ Segment } & \multicolumn{4}{c}{ Status rating thresholds and classification $(\mathbf{m})$} \\
\cline { 2 - 5 } & Poor & Fair & Good & Very good \\
\hline Lake St. Clair & $<100$ & $100-200$ & $>200$ & $>250$ \\
Main channels & $<100$ & $100-200$ & $>200$ & $>250$ \\
\hline
\end{tabular}

\section{Mean Distance of Suitable Waterfowl Habitat From Disturbance Factor}

Description.-This indicator is based on response of waterfowl to anthropogenic disturbance factors such as hiking, running, walking, and response to dogs accompanied by people, as well as response to boats.

Basis for Assessing Indicator-Status rating thresholds were taken from the LEBCS (Pearsall and others, 2012), based on Borgmann (2011) and references therein.

Approach.-Disturbance of waterfowl was calculated in ArcMap using habitat suitability data from the Great Lakes Migratory Bird Stopover Portal (Ewert and others, 2012; accessed at: https://data.pointblue.org/partners/mwadc/index. php?page=stopover-map-tool). The suitability data from the raster were extracted within a 2-km buffer along the shoreline to allow comparability across all assessment units. Roads were considered as disturbance that may alter shorebird behavior (Borgmann, 2011). To calculate the average distance to disturbances (roads), we converted the raster to points (approximately 152,000 points) to run a "near" analysis to calculate the distance (in meters) to the nearest road. The road layer was the same as used in the road density indicator. Although other factors such as trails and boat traffic alter waterfowl behavior, these factors could not be accounted for in this analysis. Therefore, the results underestimate the disturbance of waterfowl. The use of creel data to generate angling and marina/boat ramp hotspots may allow future analysis to account for boating traffic in addition to roads.

\begin{tabular}{lcccc}
\hline \multirow{2}{*}{ Segment } & \multicolumn{4}{c}{ Status rating thresholds and classification $(\mathbf{m})$} \\
\cline { 2 - 5 } & Poor & Fair & Good & Very good \\
\hline Lake St. Clair & $<100$ & $100-200$ & $>200$ & $>250$ \\
Main channels & $<100$ & $100-200$ & $>200$ & $>250$ \\
\hline
\end{tabular}




\section{Key Ecological Attribute-Habitat Availability}

\section{Percentage of 2 Kilometers Shoreline Area Suitable for Shorebirds}

Description.-Studies outside the Great Lakes Region indicate that the number or species richness of shorebirds is positively associated with the amount of wetland cover at a scale of 3-10 km (Farmer and Parent, 1997).

Basis for Assessing Indicator--Status rating thresholds were taken from the LEBCS (Pearsall and others, 2012), which used expert opinion to assign values to the proportion of suitable habitat (Farmer and Parent, 1997; Fairbairn and Dinsmore, 2001).

Approach.-Habitat suitability for shorebirds data were gathered from Shorebird Model within the Great Lakes Migratory Bird Stopover Portal (Ewert and others, 2012; accessed at: https://data.pointblue.org/partners/mwadc/index.php?page=stopovermap-tool). The model scores were downloaded from the online mapping portal as rasters. The Shorebird Model scores ranged from 0 (non-habitat) to 5 (ideal habitat) that were generated within the Shorebird Model from criteria such as distance to water bodies and land cover types. The suitability data from the raster were extracted within a 2-km buffer that spanned from along the shoreline to $2 \mathrm{~km}$ inland. Suitable habitat was considered any value greater than 1 that was converted to a polygon, and the area of suitable habitat within this $2-\mathrm{km}$ buffer was then calculated.

\begin{tabular}{rcccc}
\hline \multirow{2}{*}{ Segment } & \multicolumn{4}{c}{ Status rating thresholds and classification (percent) } \\
\cline { 2 - 5 } & Poor & Fair & Good & Very good \\
\hline Lake St. Clair & $<30$ & $30-50$ & $>50-80$ & $>80$ \\
Main channels & $<30$ & $30-50$ & $>50-80$ & $>80$ \\
\hline
\end{tabular}

\section{Percentage of 2 Kilometers Shoreline Area Suitable Habitat for Landbirds}

Description.-Undeveloped areas near shorelines are important for resident and migrant landbirds. Lower densities of migrants are found in landscapes where habitat patches have less than 40 percent natural land cover (Williams, 2002). Additionally, migrant body condition may be reduced in landscapes with less than 10 percent cover (Ktitorov and others, 2008).

Basis for Assessing Indicator-_Status rating thresholds were taken from the LEBCS (Pearsall and others, 2012), which used expert opinion to assign values to the proportion of suitable habitat.

Approach.-Habitat suitability for landbirds data were gathered from Landbird Model within the Great Lakes Migratory Bird Stopover Portal (Ewert and others, 2012; accessed at: https://data.pointblue.org/partners/mwadc/index.php?page=stopovermap-tool). The model scores were downloaded from the online mapping portal as rasters. The Landbird Model scores ranged from 0 (non-habitat) to 5 (ideal habitat) that were generated within the Landbird Model from criteria such as distance to water bodies and land cover types. The suitability data from the raster were extracted within a 2-km buffer that spanned from along the shoreline to $2 \mathrm{~km}$ inland. Suitable habitat was considered any value greater than 1 that was converted to a polygon, and the area of suitable habitat within this $2-\mathrm{km}$ buffer was then calculated.

\begin{tabular}{rcccc}
\hline \multirow{2}{*}{ Segment } & \multicolumn{4}{c}{ Status rating thresholds and classification (percent) } \\
\cline { 2 - 5 } & Poor & Fair & Good & Very good \\
\hline Lake St. Clair & $<10$ & $10-30$ & $>30-50$ & $>50$ \\
Main channels & $<10$ & $10-30$ & $>30-50$ & $>50$ \\
\hline
\end{tabular}

\section{Percentage of 2 Kilometers Shoreline Area Suitable Habitat for Waterfowl}

Description.-Because of the high co-occurrence of shorebirds and waterfowl, and a study indicating the number ducks present during migration was positively associated with wetland cover (Brennan, 2006), the indicator rating thresholds for shorebirds were adopted for waterfowl.

Basis for Assessing Indicator--Status rating thresholds were taken from the LEBCS (Pearsall and others, 2012), which used expert opinion to assign values to the proportion of suitable habitat.

Approach.-Habitat suitability for waterbirds data were gathered from Waterbird Model within the Great Lakes Migratory Bird Stopover Portal (Ewert and others, 2012; accessed at: https://data.pointblue.org/partners/mwadc/index.php?page=stopovermap-tool). The model scores were downloaded from the online mapping portal as rasters. The Waterbird Model scores ranged from 0 (non-habitat) to 5 (ideal habitat) that were generated within the Waterbird Model from criteria such as distance to water 
bodies and land cover types. The suitability data from the raster were extracted within a 2-km buffer that spanned from along the shoreline to $2 \mathrm{~km}$ inland. Suitable habitat was considered any value greater than 1 that was converted to a polygon and the area of suitable habitat within this 2-km buffer was then calculated.

\begin{tabular}{ccccc}
\hline \multirow{2}{*}{ Segment } & \multicolumn{4}{c}{ Status rating thresholds and classification (percent) } \\
\cline { 2 - 5 } & Poor & Fair & Good & Very good \\
\hline Lake St. Clair & $<30$ & $30-50$ & $>50-80$ & $>80$ \\
Main channels & $<30$ & $30-50$ & $>50-80$ & $>80$ \\
\hline
\end{tabular}

\section{Key Ecological Attribute-Management Status}

\section{Percentage of High Priority Habitat Across All Bird Groups in Conservation Management}

Description.-This indicator is a conservative approach to ensure sufficient habitat during any given time and between migration season. As with all indicators related to aerial migrants, more study is needed to refine threshold values for this indicator.

Basis for Assessing Indicator.-Status rating thresholds were taken from the LEBCS (Pearsall and others, 2012) based on expert opinion.

Approach.-Habitat suitability for all birds data were gathered from the Great Lakes Migratory Bird Stopover Portal (Ewert and others, 2012; accessed at: https://data.pointblue.org/partners/mwadc/index.php?page=stopover-map-tool), and data were only for the U.S portions of SCDRS. The resulting polygons for the previous shorebird, waterbird, and landbird analysis were intersected to calculate the area of biodiversity hotspots of migrating birds compared to land areas classified as in conservation.

\begin{tabular}{lcccc}
\hline \multirow{2}{*}{ Segment } & \multicolumn{4}{c}{ Status rating thresholds and classification (percent) } \\
\cline { 2 - 5 } & Poor & Fair & Good & Very good \\
\hline Lake St. Clair & $<50$ & $50-80$ & $>80-99$ & 100 \\
Main channels & $<50$ & $50-80$ & $>80-99$ & 100 \\
\hline
\end{tabular}




\section{References Cited}

Archer, R.W., Timmermans, S.T.A., and Robinson, C.L., 2006, Monitoring and assessing marsh habitats in Great Lakes Areas of Concern: Port Rowan, Ontario, Final Project Report, Bird Studies Canada, accessed July 20, 2018, at http://www.bsc-eoc.org/download/MMPAOCReport2007. pdf.

Archer, R.W., Wheeler, H., and Sass, D.J., 2009a, Coastal wetland bird communities-State of the Great Lakes 2009: Washington, D.C., U.S. Environmental Protection Agency, accessed November 26, 2018, at https://binational.net/ wp-content/uploads/2014/11/En161-3-1-2009E.pdf.

Archer, R.W., Wheeler, H., and Sass, D.J., 2009b, Coastal wetland amphibian communities-State of the Great Lakes 2009: Washington, D.C., U.S. Environmental Protection Agency, accessed November 26, 2018, at https://binational. net/wp-content/uploads/2014/11/En161-3-1-2009E.pdf.

Auer, M.T., Tomlinson, L.M., Higgins, S.N., Malkin, S.Y., Howell, E.T., and Bootsma, H.A., 2010, Great Lakes Cladophora in the 21st century-Same algae-Different ecosystem: Journal of Great Lakes Research, v. 36, no. 2, p. 248-255.

Baird and Associates, 2005, Flooding performance indicatorMethodology and shared vision model application: Windsor, Ontario, International Joint Commission Plan Formulation and Evaluation Group, International Joint Commission.

Beamish, F.W.H., Noakes, D.L.G., and Rossiter, A., 1998, Feeding ecology of juvenile lake sturgeon, Acipenser fulvescens, in Northern Ontario: Canadian Field Naturalist, v. 112, p. $459-468$.

Bland, D., Neave, P., Hamill, S., VanDyke, O., and Nielsen, C., 2006, Information Report No. 60c: Biodiversity and Your Eastern Ontario Woodlot: Kemptville, Ontario, Eastern Ontario Model Forest, accessed October 5, 2018, at http://www.eomf.on.ca/index.php?option=com $\mathrm{k} 2 \& \mathrm{view}=\mathrm{item} \& \mathrm{id}=179$ : biodiversity-and-your-easternontario-woodlot\&Itemid=331.

Boase, J.C., Diana, J.S., Thomas, M.V., and Chiotti, J.A., 2011, Movements and distribution of adult Lake Sturgeon from their spawning site in the St. Clair River, Michigan: Journal of Applied Ichthyology, v. 27, no. 2, p. 58-65.

Borgmann, K.L., 2011, A review of human disturbance impacts on waterbirds: Audubon California, at accessed October 5, 2018 at https://www.sfbayjv.org/resourcedocs/ Human\%20disturbance\%20impacts\%20Report\%20FINAL. pdf.
Bourgeau-Chavez, L.L., Kowalski, K.P., Carlson Mazur, M.L., Scarbrough, K.A., Powell, R.B., Brooks, C.N., Huberty, B., Jenkins, L.K., Banda, E.C., Galbraith, D.M., Laubach, Z.M., and Riordan, K., 2013, Mapping invasive Phragmites australis in the coastal Great Lakes with ALOS PALSAR satellite imagery for decision support: Journal of Great Lakes Research, v. 39, no. 1, p. 65-77.

Brennan, E.K., 2006, Local and landscape level variables influencing migratory bird abundance, diversity, behavior, and community structure in Rainwater Basin wetlands: Lubbock, Tex., Doctoral Dissertation, Texas Tech University.

Bryan, N.J., Florence, C.V., Crail, T.D., and Moorhead, D.L., 2013, Freshwater mussel community response to warm water discharge in western Lake Erie: Journal of Great Lakes Research, v. 39, no. 3, p. 449-454.

Burtner, A.M., 2009, The influence of carbon subsidies on stream chemistry and function in northern Michigan streams: Ann Arbor, Mich., M.S. Thesis, University of Michigan.

Carlson, D.L., and Swackhamer, D.L., 2006, Results from the U.S. Great Lakes fish monitoring program and effects of lake processes on bioaccumulative contaminant concentrations: Journal of Great Lakes Research, v. 32, no. 2, p. $370-385$.

Carter, C.H.; Benson, D.J.; and Guy, D.E., Jr., 1981, Shore protection structures-Effects on recession rates and beaches from the 1870s to the 1970s along the Ohio shore of Lake Erie: Environmental Geology, v. 3, no. 6, p. 353-362.

Childress, E., 2010, Native fish migrations deliver nutrient subsidies to Great Lakes tributaries: Ann Arbor, Mich., M.S. Thesis, University of Michigan.

Chiotti, J., Mohr, L., Thomas, M., Boase, J., and Manny, B., 2013, Lake sturgeon population demographics in the HuronErie Corridor, 1996-2012: Nanaimo, Canada, Oral presentation at the International Sturgeon Symposium, July 21-25, 2013.

Choudhury, A., Bruch, R., and Dick, T.A., 1996, Helminths and food habits of lake sturgeon Acipenser fulvescens from the Lake Winnebago system, Wisconsin: American Midland Naturalist, v. 135 , no. 2, p. 274-282.

Chow-Fraser, P., 2006, Development of the Water Quality Index (WQI) to assess effects of basin-wide land use alteration on coastal marshes of the Laurentian Great Lakes, in Simon, T.P., and Stewart, P.M., eds., Coastal wetlands of the Laurentian Great Lakes-Health, habitat and indicators: Bloomington, Ind., Authorhouse Press, p. 137-166. 
Clady, M., and Hutchinson, B., 1976, Food of the yellow perch, Perca flavescens, following a decline of the burrowing mayfly, Hexagenia limbata: Ohio Journal of Science, v. 76 , no. 3, p. 133-138.

Crail, T.D., Krebs, R.A., and Zanatta, D.T., 2011, Unionid mussels from nearshore zones of Lake Erie: Journal of Great Lakes Research, v. 37, no. 1, p. 199-202.

Crewe, T.L., and Timmermans, S.T.A., 2005, Assessing biological integrity of Great Lakes coastal wetlands using marsh bird and amphibian communities: Port Rowan, Ontario, Technical Report Project\# WETLAND3-EPA-01, Bird Studies Canada.

Croft, M.V., and Chow-Fraser, P., 2007, Development of the wetland macrophyte index to detect degree of water-quality impairment in Great Lakes Coastal Marshes: Journal of Great Lakes Research, v. 33, sup. 3, p. 172-197.

Cushing, D.H., 1990, Plankton production and year-class strength in fish populations - An update of the match/mismatch hypothesis: Advances in Marine Biology, v. 26, p. 249-293.

Davies, D.H., Haas, B., Halyk, L., Kenyon, R., Mackey, S., Markham, J., Roseman, E., Ryan, P., Tyson, J., and Wright, E., 2005, Lake Erie Environmental Objectives: Ann Arbor, Mich., Great Lakes Fishery Commission, accessed November 27, 2018 at http://www.glfc.org/pubs/lake_committees/ erie/EOs_July5.pdf.

De Vault, D.S., Hesselberg, R.J., Rodgers, P.W., and Feist, T.J., 1996, Contaminant trends in lake trout and walleye from the Laurentian Great Lakes: Journal of Great Lakes Research, v. 22 , p. $884-895$.

Dodd, C.K., and Smith, L.L., 2003, Habitat destruction and alteration-Historical trends and future prospects for amphibians in Semlitsch, R.D, ed., Amphibian Conservation: Washington, D.C., Smithsonian Books, p. 94-112.

Eakins, R.J., 2013, Ontario freshwater fishes life history database-Version 4.37: Online database, accessed July 20, 2018, at http://www.ontariofishes.ca.

Edsall, T.A., Bur, M.T., Gorman, O.T., and Schaeffer, J.S., 2005, Burrowing mayflies as indicators of ecosystem health-Status of populations in western Lake Erie, Saginaw Bay and Green Bay: Aquatic Ecosystem Health and Management, v. 8, no. 2, p. 107-116.

Environment Canada, and Central Lake Ontario Conservation Authority, 2004, Durham Region Coastal Wetland Monitoring Project: Downsview, Ontario, Environment Canada, Year Two Technical Report, ECB-OR.
Environment Canada, and U.S. Environmental Protection Agency, 2007, State of the Great Lakes 2007: Ottawa, Ontario, and Washington, D.C., Environment Canada and U.S. Environmental Protection Agency, accessed November 27, 2018, at http://publications.gc.ca/collections/ collection_2008/ec/En161-3-1-2007E.pdf.

Environment Canada, and U.S. Environmental Protection Agency, 2009, State of the Great Lakes 2009: Ottawa, Ontario and Washington, D.C., Environment Canada and U.S. Environmental Protection Agency, accessed November 27, 2018, at https://binational.net//wp-content/ uploads/2014/11/En161-3-1-2009E.pdf.

Environment Canada, and U.S. Environmental Protection Agency, 2014, State of the Great Lakes 2011: Cat No. En161-3/1-2011E-PDF, EPA 950-R-13-002, accessed November 27, 2018, at https://binational.net//wp-content/ uploads/2014/11/sogl-2011-technical-report-en.pdf.

Esri, 2010, ArcMap [GIS software]_-Version 9.3: Redlands, Calif., Environmental Systems Research Institute.

Ewert, D.N., Doran, P.J., Hall, K.R., Froehlich, A., Cannon, J., Cole, J.B., and France, K.E., 2012, On a wing and a (GIS) layer-Prioritizing migratory bird stopover habitat along Great Lakes shorelines: Bloomington, N.Y., Final report to the Upper Midwest/Great Lakes Landscape Conservation Cooperative.

Ewert, D.N., and Hamas, M.J., 1995, Ecology of migratory landbirds during migration in the Midwest, in F.R. Thompson, III, ed., Management of Midwestern landscapes for the conservation of neotropical migratory birds: U.S. Department of Agriculture, Forest Service, North Central Forest Experiment Station, Gen. Tech. Rep. NC-187, p. 208.

Fairbairn, S.E., and Dinsmore, J.J., 2001, Local and landscape-level influences on wetland bird communities of the prairie pothole region of Iowa, USA: Wetlands, v. 21, no. 1, p. $41-47$.

Farmer, A.H., and Parent, A.H., 1997, Effects of the landscape on shorebird movements at spring migration stopovers: The Condor, v. 99, no. 3, p. 698-707.

Findlay, C.S., Lenton, J., and Zheng, L.G., 2001, Land-use correlates of anuran community richness and composition in southeastern Ontario wetlands: Ecoscience, v. 8, no 3. p. 336-343.

Fischer, J.L., Pritt, J.J., Roseman, E.F., Prichard, C.G., Craig, J.M., Kennedy, G.W., and Manny, B.A., 2018, Lake Sturgeon, Lake Whitefish, and Walleye egg deposition patterns with response to fish spawning substrate restoration in the St. Clair-Detroit River System: Transactions of the American Fisheries Society, v. 147, no. 1, p. 79-93. 
Flecker, A.S., McIntyre, P.B., Moore, J.W., Anderson, J.T., Taylor, B.W., and Hall, R.O., 2010, Migratory fishes as material and process subsidies in riverine ecosystems: American Fisheries Society Symposium, v. 73, p. 559-592.

Forman, R.T.T., 1997, Landscape mosaics-The ecology of landscapes and regions: New York, Cambridge University Press.

Forman, R.T.T., and Collinge, S.K.,1997, Nature conserved in changing landscapes with and without spatial planning: Landscape and Urban Planning, v. 37, no. 1-2, p. 129-135.

Franks Taylor, R., Derosier, A., Dinse, K., Doran, P., Ewert, D., Hall, K., Herbert, M., Khoury, M., Kraus, D., Lapenna, A., Mayne, G., Pearsall, D., Read, J., and Schroeder, B., 2010, The Sweetwater Sea-An international biodiversity conservation strategy for Lake Huron-Technical Report: Lansing, Mich., The Nature Conservancy, 264 p., appendixes.

Gillis, P.L., and Mackie, G.L., 1994, Impact of zebra mussels, Dreissena polymorpha, on populations of Unionidae (Bivalvia) in Lake St. Clair: Canadian Journal of Zoology, v. 72, no. 7 , p. 1260-1271.

Goforth, R.R., and Carman, S.M., 2005, Nearshore community characteristics related to shoreline properties in the Great Lakes: Journal of Great Lakes Research, v. 31, sup. 1, p. 113-128.

Goodyear, C.D., Edsall, T.A., Dempsey, D.M.O., Moss, G.D., and Polanski, P.E., 1982, Atlas of the spawning and nursery areas of Great Lakes fishes, volume IX —-Lake Erie: Ann Arbor, Mich., U.S. Fish and Wildlife Service FWS/OBS 82/52, 193 p. accessed July 23, 2018, at https://www.glsc. usgs.gov/sites/default/files/product_files/volume09.pdf.

Grabas, G.P., Crewe, T.L., and Timmermans, S.T.A., 2008, Bird community indicators, in Burton, T.M., Brazner, J.C., Ciborowksi, J.J.H., Grabas, G.P., Hummer, J., Schneider, J., and Uzarski, D.G., eds., Great Lakes coastal wetlands monitoring plan: Great Lakes Coastal Wetlands Consortium, p. 118-144, accessed November 27, 2018, at https://www. glc.org/wp-content/uploads/2016/10/Great-Lakes-CoastalWetlands-Monitoring-Plan-FINAL-March-2008.pdf.

Great Lakes Coastal Wetlands Consortium, 2004, Great Lakes Coastal Wetland Inventory, accessed November 27, 2018, at https://www.glc.org/library/2008-great-lakes-coastalwetland-monitoring-plan.

Great Lakes Fishery Commission, 2012, Report of the Lake Erie Forage Task Group, March 2012: Presented to Standing Technical Committee, Lake Erie Committee, accessed November 27, 2018, at http://www.glfc.org/pubs/ lake_committees/erie/FTG_docs/annual_reports/FTG report_2012.pdf.
Harris, R., Kinder, B., Marino, A., Parker-Geisman, V., and Patterson T., 2009, The St. Marys River Watershed-Planning for biodiversity conservation: Ann Arbor, Mich., M.S. Thesis, University of Michigan.

Hartig, J.H., Zarull, M.A., Ciborowski, J.H., Gannon, J.E., Wilke, E., Norwood, G., and Vincent, A., eds., 2007, State of the Strait-Status and trends of key indicators, 2007: Great Lakes Institute for Environmental Research, Occasional Publication No. 5., Ontario, Canada, University of Windsor, accessed November 26, 2018, at http:/www. waterwebster.com/documents/State-of-theStrait.pdf.

Hayes, D.B., and Caroffino, D.C., eds., 2012, Michigan's lake sturgeon rehabilitation strategy: Lansing, Mich., Michigan Department of Natural Resources, Fisheries Division Special Report 62, 18 p.

Hecky, R.E., Smith, R.E.H., Barton, D.R., Guildford, S.J., Taylor, W.D., Charlton, M.N., and Howell, T., 2004, The nearshore phosphorus shunt-A consequence of ecosystem engineering by Dreissenids in the Laurentian Great Lakes: Canadian Journal of Fisheries and Aquatic Sciences, v. 61, no. 7 , p. 1285-1293.

Helms, B.S., Feminella, J.W., and Pan, S., 2005, Detection of biotic responses to urbanization using fish assemblages from small streams of western Georgia, USA: Urban Ecosystems, v. 8, no. 1, p. 39-57.

Herdendorf, C.E., 1973, Shoreline changes of Lakes Erie and Ontario-With special reference to currents, sediment transport and shore erosion: Columbus, Ohio, The Ohio State University Center for Lake Erie Area Research.

Herdendorf, C.E., 1987, Analysis of shore recession rates and beach processes at the base of Cedar Point, Lake Erie, Erie County, Ohio: Put-in-Bay, Ohio, Ohio State University, Center for Lake Erie Area Research.

Herdendorf, C.E., Raphael, C.D., and Jaworski, E., 1986, The ecology of Lake St. Clair wetland-A community profile: U.S. Fish and Wildlife Service Biological Report, v. 85, no. 7.7.

Hjort, J., 1914, Fluctuations in the great fisheries of Northern Europe, viewed in the light of biological research: Conseil Parmanent International Pour L'Exploration De La Mar, Rapports et Proces-Verbaux, v. 20, p. 1-228.

Houlahan, J.E., and Findlay, C.S., 2003, The effects of adjacent land use on wetland amphibian species richness and community composition: Canadian Journal of Fisheries and Aquatic Sciences, v. 60, no 9, p. 1078-1094.

International Upper Great Lakes Study, 2011, Options for restoring Lake Michigan-Huron water levels-An exploratory analysis: Ottawa, Ontario, International Joint Commission. 
Klingler, G.L., Adams, J.F., and Heinrich, J.W., 2003, Passage of four teleost species prior to sea lamprey (Petromyzon marinus) migration in eight tributaries of Lake Superior, 1954 to 1979: Journal of Great Lakes Research, v. 29, sup. 1, p. 403-409.

Knapton, R.W., and Petrie, S.A., 1999, Changes in distribution and abundance of submerged macrophytes in the inner bay at Long Point, Lake Erie-Implications for foraging waterfowl: Journal of Great Lakes Research, v. 25, no. 4, p. 783-798.

Ktitorov, P., Bairlein, F., and Dubinin, M., 2008, The importance of landscape context for songbirds on migration: body mass gain is related to habitat cover: Landscape Ecology, v. 23 , no. 2 , p. $169-179$.

Lake Erie Lakewide Action and Management Plan, 2011, Lake Erie binational nutrient management strategy-Protecting Lake Erie by managing phosphorus: Prepared by the Lake Erie Lakewide Action and Management Plan Work Group Nutrient Management Task Group, accessed November 26, 2018, at https://www.epa.gov/greatlakes/lake-eriebinational-nutrient-management-strategy.

Lake Ontario Biodiversity Strategy Working Group, 2009, The beautiful lake - A bi-national biodiversity conservation strategy for Lake Ontario: Developed in co-operation with the U.S.-Canada Lake Ontario Lakewide Management Plan, 40 p., accessed July 24, 2018, at

https://www.conservationgateway.org/

ConservationByGeography/NorthAmerica/UnitedStates/ michigan/Documents/LOBCS\%20Report.pdf.

Lane, J.A., Portt, C.B., and Minns, C.K., 1996, Spawning habitat characteristics of Great Lakes fishes: Sarnia, Ontario, Canadian Manuscript Report of Fisheries and Aquatic Sciences 2368, Department of Fisheries and Oceans Canada, accessed November 26, 2018, at http://publications.gc.ca/ site/eng/9.562511/publication.html.

Leach, J.H., and Nepszy. S.J., 1976, The fish community of Lake Erie: Journal of the Fisheries Research Board of Canada, v. 33, no. 3, p. 622-638.

Li, R., Liu, J., and Felus. Y., 2001, Spatial modeling and analysis of shoreline change detection and coastal erosion monitoring: Marine Geodesy, v. 24, no. 1, p. 1-12.

Lougheed, V.L., and Chow-Fraser, P., 2002, Development and use of a zooplankton index of wetland water quality in the Laurentian Great Lakes Basin: Ecological Applications, v. 12 , no. 2, p. 474-486.
Lougheed, V.L., Crosbie, B., and Chow-Fraser, P., 2001, Primary determinants of macrophyte community structure in 62 marshes across the Great Lakes Basin - Latitude, land use, and water quality effects: Canadian Journal of Fisheries and Aquatic Sciences, v. 58, no. 8, p. 1603-1612.

Ludsin, S.A., Kershner, M.W., Blocksom, K.A., Knight, R.L., and Stein, R.A., 2001, Life after death in Lake Erie-Nutrient controls drive fish species richness, rehabilitation: Ecological Applications, v. 11, no. 3, p. 731-746.

Mackey, S.D., and Liebenthall, D.L., 2005, Mapping changes in Great Lakes nearshore substrate distributions: Journal of Great Lakes Research, v. 31, sup. 1, p. 75-89.

MacLennan, D., Haas, R.C., Braunscheidel, J., Francis, J., Halyk, L., Hector, D., Locke, B., McGregor, R., Morencie, M., Murray, A., Roseman, E., Thomas, M.V., and Towns, G., 2003, Draft fish community goal and objectives for Lake St. Clair, St. Clair River, and Detroit River (St. Clair System): Ann Arbor, Mich., Great Lakes Fishery Commission Special Publication Draft, accessed July 25, 2018, at http://www.glfc.org/pubs/lake_committees/erie/scsfcgo.pdf.

Manny, B.A, 2007, Detroit River Coastal Wetlands, in Hartig, J.H., Zarull, M.A., Ciborowski, J.J.H., Gannon, J.E., Wilke, E., Norwood, G., and Vincent, A., eds., State of the StraitStatus and trends of key indicators: Great Lakes Institute for Environmental Research, Occasional Publication No. 5, University of Windsor, Ontario, p. 171-176, accessed August 31, 2018, at http://web2.uwindsor.ca/softs/reports/ SOFTS_2007_Report.pdf.

Manny, B.A., Kennedy, G.W., Boase, J.C., Allen, J.D., and Roseman, E.F., 2010, Spawning by walleye (Sander vitreus) and white sucker (Catostomus commersoni) in the Detroit River-Implications for spawning habitat enhancement: Journal of Great Lakes Research, v. 36, no. 3, p. 490-496.

Marsden, J.E., and Chotkowski, M.A., 2001, Lake trout spawning on artificial reefs and the effect of zebra mussels - Fatal attraction?: Journal of Great Lakes Research, v. 27 , no. 1, p. $33-43$.

Marsh Monitoring Program, 2009, Marsh Monitoring Program participant's handbook for surveying marsh birds, revised 2008: Port Rowan, Ontario, Bird Studies Canada in cooperation with Environment Canada and the U.S. Environmental Protection Agency.

Master, L.L., 1990, The imperiled status of North American aquatic animals: Biodiversity Network News, v. 3, no. 1-2, p. 7-8. 
McGoldrick, D.J., Metcalfe-Smith, J.L., Arts, M.T., Schloesser, D.W., Newton, T.J., Mackie, G.L., Monroe, E.M., Biberhofer, J., and Johnson, K., 2009, Characteristics of a refuge for native freshwater mussels (Bivalvia-Unionidae) in Lake St. Clair: Journal of Great Lakes Research, v. 35 , no. 1 , p. 137-146.

Meadows, G.A.; Mackey, S.D.; Goforth, R.R.; Mickelson, D.M.; Edil, T.B.; Fuller, J.; Guy, D.E., Jr.,; Meadows, L.E.; Brown, E.; Carman, S.M.; and Liebenthal, D.L., 2005, Cumulative habitat impacts of nearshore engineering: Journal of Great Lakes Research, v. 31, sup. 1, p. 90-112.

Michigan Department of Environmental Quality, 2013, Michigan's water chemistry monitoring program, A report of statewide spatial patterns 2005-2009 and fixed station status and trends 1998-2008: Lansing, Mich., Report MI/DEQ/ WRD-13-005, Michigan Department of Environmental Quality.

Mion, J.B., Stein, R.A., and Marschall, E.A.,1998, River discharge drives survival of larval walleye: Ecological Applications, v. 8, no. 1, p. 88-103.

Monson, B.A., Staples, D.F., Bhavsar, S.P., Holsen, T.M., Schrank, C.S., Moses, S.K., McGoldrick, D.J., Backus, S.M., and Williams, K.A., 2011, Spatiotemporal trends of mercury in walleye and largemouth bass from the Laurentian Great Lakes Region: Ecotoxicology, v. 20, no. 7, p. $1555-1567$.

Morang, A., Frey, A., Bucaro, D., Brodzinsky, S., and Fuller, J., 2012, Sediment budget for the Indiana shore from Michigan City harbor to Burns Waterway Harbor: Chicago, Ill., U.S. Army Corps of Engineers.

Morang, A., Mohr, M.C., and Forgette, C.M., 2011, Longshore sediment movement and supply along the U.S. shoreline of Lake Erie: Journal of Coastal Research, v. 27, no. 4, p. 619-635.

Murcia, C., 1995, Edge effects in fragmented forests: implications for conservation: Trends in Ecology and Evolution, v. 10 , p. $58-62$.

Nalepa, T.F., Hartson, D.J., Gostenik, G.W., Fanslow, D.L., and Lang, G.A., 1996, Changes in the freshwater mussel community of Lake St. Clair-From Unionidae to Dreissena polymorpha in eight years: Journal of Great Lakes Research, v. 22, no. 2, p. 354-369.

Newmark, W.D., 1995, Extinction of mammal populations in western North American national parks: Conservation Biology, v. 9, no. 3, p. 512-526.
Niemi, G.J., Brady, V.J., Brown, T.N., Ciborowski, J.J.H., Danz, N.P., Ghioca, D.M., Hanowski, J.M., Hollenhorst, T.P., Howe, R.W., Johnson, L.B., Johnston, C.A., and Reavie, E.D., 2009, Development of ecological indicators for the U.S. Great Lakes coastal region-A summary of applications in Lake Huron: Aquatic Ecosystem Health \& Management, v. 12, no. 1, p. 1-13.

Ontario Ministry of Natural Resources, 2014, 2013 Status of major stocks, Lake Erie Management Unit: Toronto, Ontario, Queen's Printer for Ontario, 120p., accessed November 27, 2018, at http://www.ontla.on.ca/library/ repository/ser/259883/2013.pdf.

Ouyang, D., Bartholic, J., and Selegean, J., 2005, Assessing sediment loading from agricultural croplands in the Great Lakes Basin: The Journal of American Science, v. 1, p. 14-21.

Pearsall, D., Carton de Grammont, P., Cavalieri, C., Chu, C., Doran, P., Elbing, L., Ewert, D., Hall, K., Herbert, M., Khoury, M., Kraus, D., Mysorekar, S., Paskus, J., and Sasson, A., 2012, Returning to a healthy lake-An international biodiversity conservation strategy for Lake Erie: Lansing, Mich., Technical Report, a joint publication of The Nature Conservancy, Nature Conservancy of Canada, and Michigan Natural Features Inventory, 340 p., appendixes.

Price, J.W., 1963, A study of the food habits of some Lake Erie fish: Bulletin of the Ohio Biological Survey, v. 2, no. 1, $89 \mathrm{p}$.

Prichard, C.G., Craig, J.M., Roseman, E.F., Fischer, J.L., Manny, B.A., and Kennedy, G.W., 2017, Egg deposition by lithophilic-spawning fishes in the Detroit and St. Clair Rivers, 2005-14: U.S. Geological Survey Scientific Investigations Report 2017-5003, 20 p., https://doi.org/10.3133/ sir20175003.

Reid, S.M., Mandrak, N.E., Carl, L.M., and Wilson, C.C., 2008a, Influence of dams and habitat condition on the distribution of redhorse (Moxostoma) species in the Grand River watershed, Ontario: Environmental Biology of Fishes, v. 81, no. 1, p. 111-125.

Reid, S.M., Wilson, C.C., Carl, L.M., and Zorn, T.G., 2008b, Species traits influence the genetic consequences of river fragmentation on two co-occurring redhorse (Moxostoma) species: Canadian Journal of Fisheries and Aquatic Sciences, v. 65, no. 5, p. 1892-1904.

Ritchie, B.J., and Colby, P.J., 1988, Even-odd year differences in walleye year-class strength related to mayfly production: North American Journal of Fisheries Management, v. 8, no. 2, p. 210-215. 
Riitters, K.H., and Wickham, J.D., 2003, How far to the nearest road?: Frontiers in Ecology and Environment, v. 1, no. 3, p. $125-129$.

Robinson, S.K.; Thompson F.R., III; Donovan, T.M.; Whitehead, D.R.; and Faaborg, J., 1995, Regional forest fragmentation and the nesting success of migratory birds: Science, v. 267 , no. 5206 , p. $1987-1990$.

Roseman, E.F., Kennedy, G.W., Boase, J.A., Manny, B.A., Todd, T.N., and Stott, W., 2007, Evidence of lake whitefish spawning in the Detroit River-Implications for habitat and population recovery: Journal of Great Lakes Research, v. 33 , no. 2 , p. 397-406.

Roseman, E.F., Kennedy, G.W., Manny, B.A., Boase, J., and McFee, J., 2012, Life history characteristics of a recovering lake whitefish Coregonus clupeaformis stock in the Detroit River, North America: Fundamental and Applied Limnology, Special Issues, Advances in Limnology, v. 63, p. $477-501$.

Rubbo, M.J., and Kiesecker, J.M., 2005, Amphibian breeding distribution in an urbanized landscape: Conservation Biology, v. 19, no. 2, p. 504-511.

Ryan, P.A., Knight, R., MacGregor, R., Towns, G., Hoopes, R., and Culligan, W., 2003, Fish-community goals and objectives for Lake Erie: Ann Arbor, Mich., Great Lakes Fishery Commission Special Publication 03-02, 56 p., accessed July 25, 2018, at http://www.glfc.org/pubs/ SpecialPubs/Sp03_2.pdf.

Saab, V.,1999, Importance of spatial scale to habitat use by breeding birds in riparian forests - A hierarchical analysis: Ecological Applications, v. 9, no. 1, p. 135-151.

Sass, D.J., Uzarski, D.G., Burton, T.M., Brazner, J., Jude, D., and Ciborowski, J.J.H., 2009, Coastal wetland fish community health - State of the Great Lakes 2009: Washington, D.C., U.S. Environmental Protection Agency, accessed November 26, 2018, at https://binational.net/wp-content/ uploads/2014/11/En161-3-1-2009E.pdf.

Schloesser, D.W., Nalepa, T.F., and Mackie, G.L., 1996, Zebra mussel infestation of unionid bivalves (Unionidae) in North America: American Zoologist, v. 36, no. 3, p. 300-310.

Strahler, A.N., 1957, Quantitative analysis of watershed geomorphology: Transactions American Geophysical Union, v. 38, no. 6, p. 913-920.

Thomas, M.V., and Haas, R.C., 2002, Abundance, age structure, and spatial distribution of lake sturgeon, Acipenser fulvescens, in the St. Clair System: Journal of Applied Ichthyology, v. 18, no. 4-6, p. 495-501.
Thomas, M.V., and Haas, R.C., 2012, Status of Lake St. Clair submerged plants, fish community, and sport fishery: Michigan Department of Natural Resources Fisheries Division, Fisheries Research Report 2099, 90 p., accessed July 25, 2018, at http://www.michigandnr.com/PUBLICATIONS/ PDFS/ifr/ifrlibra/research/reports/2099/RR2099.pdf.

Thomas, M.V., and Towns, G.L., 2011, Summary of creel survey results for the St. Clair River, Lake St. Clair, and the Detroit River, 2002-05: Michigan Department of Natural Resources Fisheries Division, Fisheries Technical Report 2011-1, 71 p., accessed July 25, 2018, at https:/www. michigan.gov/documents/dnr/TR2011-1_351864_7.pdf.

Thomas, M.V., and Wills, T., 2013, Status of the fisheries in Michigan waters of Lake Erie and Lake St. Clair, 2012, Prepared for the Great Lakes Fishery Commission Lake Erie Committee: Lansing, Mich., Michigan Department of Natural Resources, accessed November 27, 2018, at https://www.michigan.gov/documents/dnr/LSCFRSstatus-2012_414757_7.pdf.

Timmermans, S.T.A., Crewe, T.L., and Grabas, G.P., 2008, Amphibian community indicators, in Burton, T.M., Brazner, J.C., Ciborowksi, J.J.H., Grabas, G.P., Hummer, J., Schneider, J., and Uzarski, D.G., eds., p. 94-117: Great Lakes coastal wetlands monitoring plan, Great Lakes Coastal Wetlands Consortium, accessed November 27, 2018, at https://www.glc.org/wp-content/uploads/2016/10/ Great-Lakes-Coastal-Wetlands-Monitoring-Plan-FINALMarch-2008.pdf.

Trautman, M.B., 1981, The fishes of Ohio: Columbus, Ohio, Ohio State University Press, 782 p.

Tucker, T.R., Roseman, E.F., DeBruyne, R.L., Pritt, J.J., Bennion, D.H., Hondorp, D.W., and Boase, J.C., 2018, Long-term assessment of ichthyoplankton in a large North American river system reveals changes in fish community dynamics: Canadian Journal of Fisheries and Aquatic Sciences, v. 75 , no. 12 , p. 2255-2270.

United States, and Canada, 2012, Great Lakes Water Quality Agreement of 2012: accessed November 27, 2018, at https://legacyfiles.ijc.org/tinymce/uploaded/GLWQA $\% 20$ 2012.pdf.

URS Corporation, and Gomez and Sullivan Engineers, P.C., 2005, Surface water quality of the Niagara River and its U.S. Tributaries: New York Power Authority, Niagara Power Project FERC No. 2216, accessed July 25, 2018, at http://niagara.nypa.gov/ALP\%20working\%20documents/ finalreports/html/IS30.htm. 
Uzarski, D.G., Burton, T.M., Cooper, M.J., Ingram, J.W., and Timmermans, S.T.A., 2005, Fish habitat use within and across wetland classes in coastal wetlands of the five Great Lakes-Development of a fish-based index of biotic integrity: Journal of Great Lakes Research, v. 31, sup. 1, p. 171-187.

Uzarski, D.G., Burton, T.M., and Genet, J.A., 2004, Validation and performance of an invertebrate index of biotic integrity for Lakes Huron and Michigan fringing wetlands during a period of lake level decline: Aquatic Ecosystem Health and Management, v. 7, no. 2, p. 269-288.

Vaughn, C.C., Nichols, S.J., and Spooner, D.E., 2008, Community and foodweb ecology of freshwater mussels: Journal of the North American Benthological Society, v. 27, no. 2, p. 409-423.

Ward, J.M., and Ricciardi, A., 2010, Community-level effects of co-occurring native and exotic ecosystem engineers: Freshwater Biology, v. 55, no. 9, p. 1803-1817.

Webb, P., 2008, The impact of changes in water level and human development on forage fish assemblages in Great Lakes coastal marshes: Journal of Great Lakes Research, v. 34, no. 4, p. 615-630.

Williams, C.L., 2002, Distribution of migratory land birds among forest patches in southern Illinois during spring stopover: Carbondale, Ill., Doctoral Dissertation, Southern Illinois University.

Zollweg, E.C., Elliott, R.F., Hill, T.D., Quinlan, H.R., Trometer, E., and Weisser, J.W., 2003, Great Lakes lake sturgeon coordination meeting, Proceedings of the December 11-12, 2002 workshop: Great Lakes lake sturgeon coordination meeting, Sault Ste. Marie, Michigan, 135 p., accessed November 27, 2018, at https://www.fws.gov/midwest/ sturgeon/documents/glsturgeoncoordmttg02.pdf. 
For more information about this publication, contact

Director, Great Lakes Science Center

1451 Green Road

Ann Arbor, Michigan 48105

734-994-3331

For additional information visit https://www.usgs.gov/locations/great-lakes-science-center

Publishing support provided by Madison and Rolla Publishing Service Centers 



\section{$\frac{\mathbb{3}}{\mathrm{C}}$}

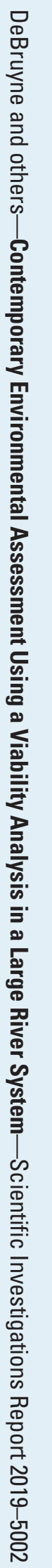

